\title{
MODELING AND ANALYSIS OF A PHOTOVOLTAIC SYSTEM WITH A DISTRIBUTED ENERGY STORAGE SYSTEM
}

\author{
A Thesis \\ presented to \\ the Faculty of California Polytechnic State University, \\ San Luis Obispo
}

\author{
In Partial Fulfillment \\ of the Requirements for the Degree \\ Master of Science in Electrical Engineering
}

by

Anthony W. Ma

May 2012 
(C) 2012

Anthony W. Ma

\section{ALL RIGHTS RESERVED}


TITLE:

AUTHOR:

DATE SUBMITTED:

COMMITTEE CHAIR:

COMMITTEE MEMBER:

COMMITTEE MEMBER:
Modeling and Analysis of a Photovoltaic System with a Distributed Energy Storage System

Anthony W. Ma

May 2012

Dr. Taufik, Professor

Dr. Ahmad Nafisi, Professor

Dr. Ali Shaban, Professor 


\begin{abstract}
Modeling and Analysis of a Photovoltaic System with a Distributed Energy Storage System

Anthony W. Ma
\end{abstract}

As California continues to integrate more renewable energy into its electrical system, the state has experienced a corresponding rise in photovoltaic system installations. PV arrays are a unique source of power generation in that they are affected by the location of the sun, shading, and temperature changes. These characteristics make solar one of the most highly variable forms of renewable energy. In order to improve solar power's consistency, PV systems require a supplemental source of power. The primary focus of this paper is to determine if distributed energy storage systems can be used to reduce the effect of solar intermittency. This paper examines the test data and system specifications of an experimental DESS. The benefits of using a DESS in a PV system are further studied using computer simulation modeling. This paper also shows through computer simulations how a maximum power point tracker can increase a PV array's power output. The results of this thesis demonstrate that DESS's are capable of smoothing out highly variable load profiles caused by intermittent solar power.

Keywords: Energy, Power, Solar, Photovoltaic, Renewable, Intermittency, Distributed, DESS, Storage, Battery 


\section{ACKNOWLEDGMENTS}

It brings me great pleasure to thank the people who helped to make this thesis possible.

First, I would like to thank my teacher and advisor Dr. Taufik. Your passion and enthusiasm for power engineering were the things that captured my interest in the specialization early on. It was due to your leadership and guidance that I learned of this project. Thank you for keeping my research interests in mind and thank you for all your hard work, I greatly appreciate it.

Next, I would like to thank Bill Torre, Mike Turner, and Steven Garrett at San Diego Gas and Electric for proposing this thesis and for helping me with the data and specifications of this project.

Finally, I would like to thank my parents, Brian and Lyleng Ma for their love and support. This thesis is the culmination of many years of hard work and it would not have been possible without their dedication. I am thankful for the sacrifices that you both made so that I could achieve my goals.

Disclaimer:

SDG\&E does not endorse or accept the conclusions or results of this study. 


\section{TABLE OF CONTENTS}

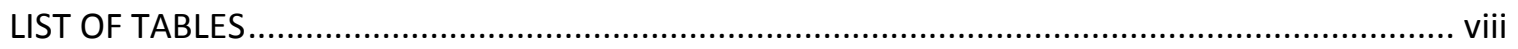

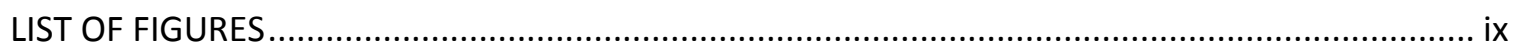

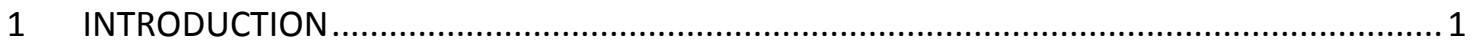

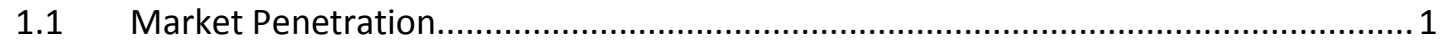

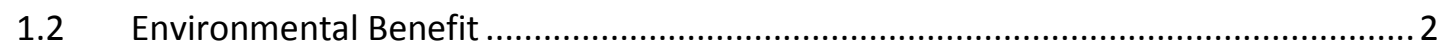

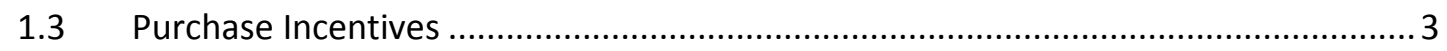

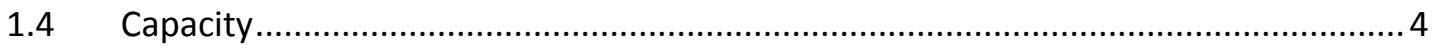

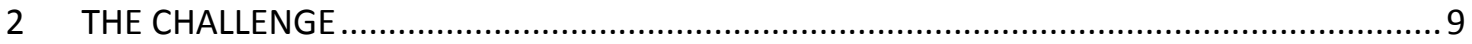

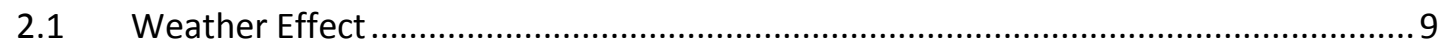

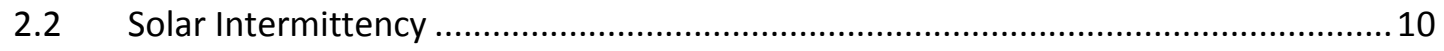

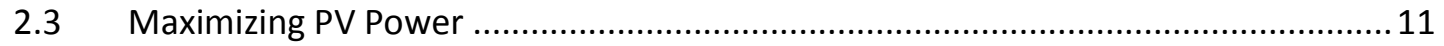

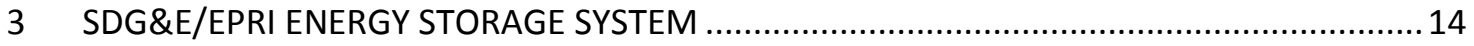

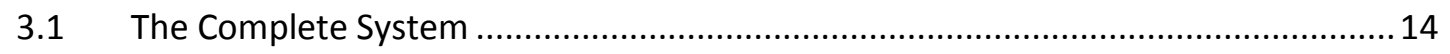

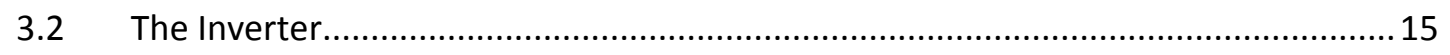

3.3 The Battery Management System ……….......................................................... 16

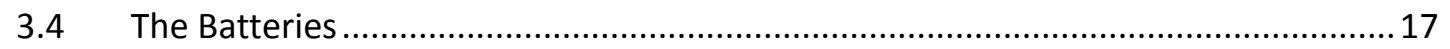

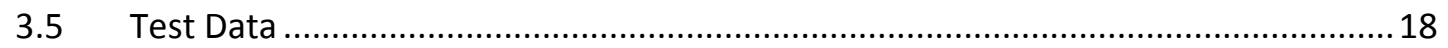

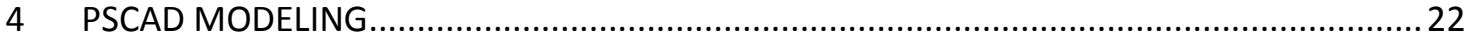

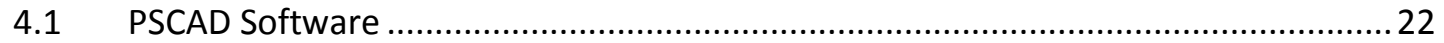

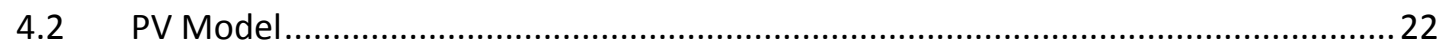

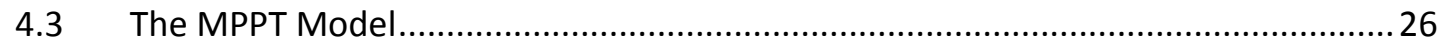

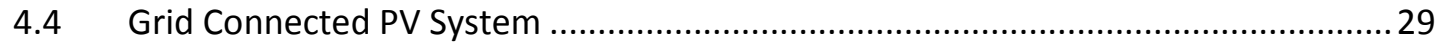

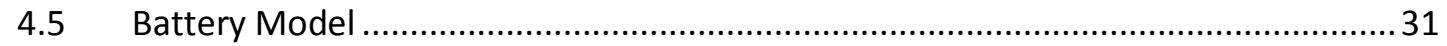

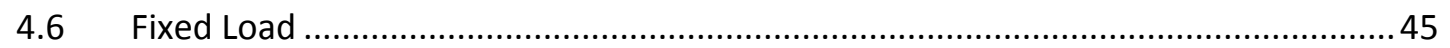

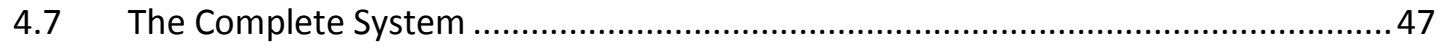

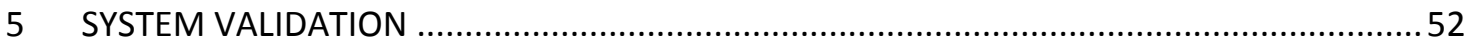

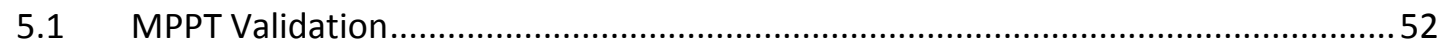

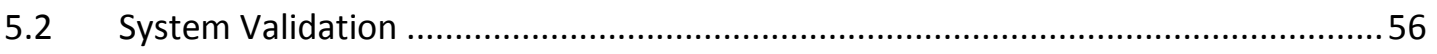

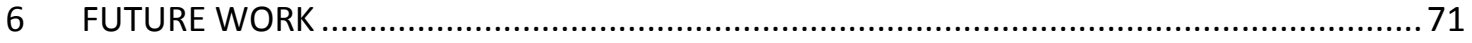




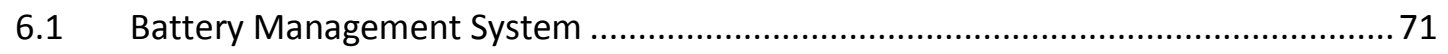

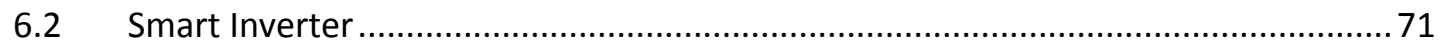

6.3 Single-Phase Inverter System Modeling …......................................................... 72

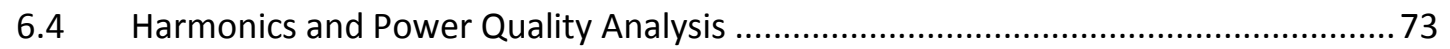

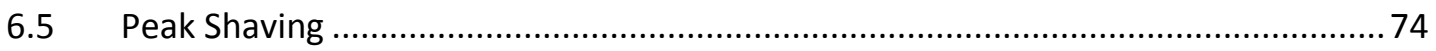

$7 \quad$ CONCLUSION

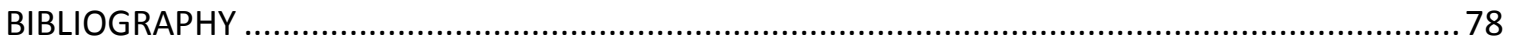

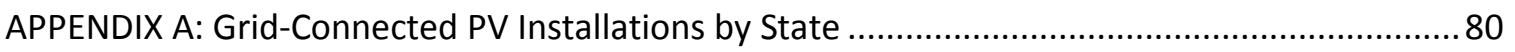

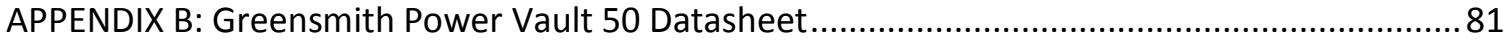

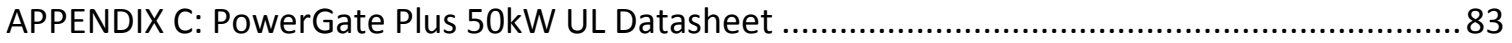

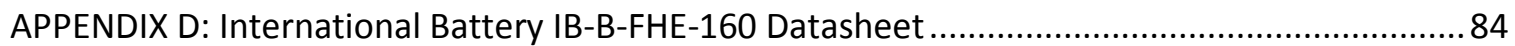




\section{LIST OF TABLES}

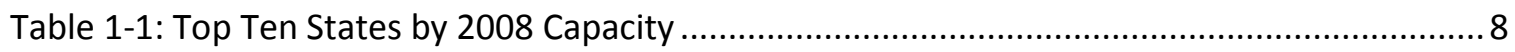

Table 1-2: Top Ten States by Cumulative Capacity .................................................................... 8

Table 1-3: Top Ten States by Per Capita Capacity.................................................................. 8

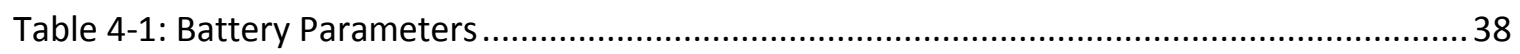

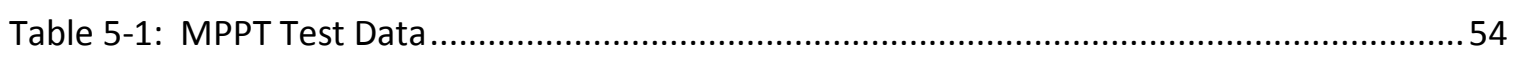

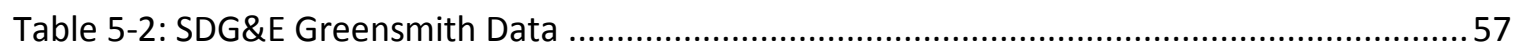

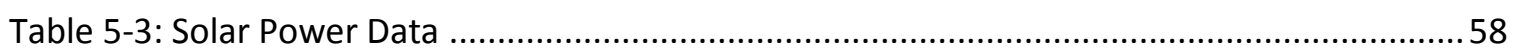

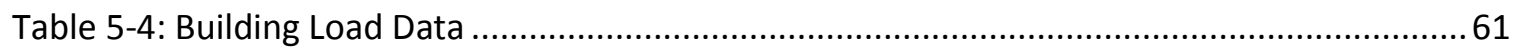

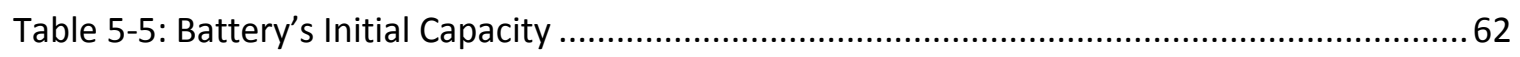

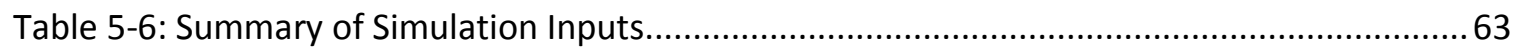

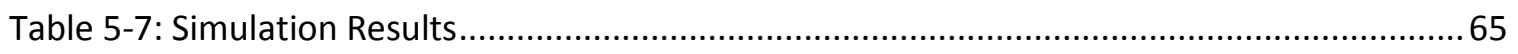

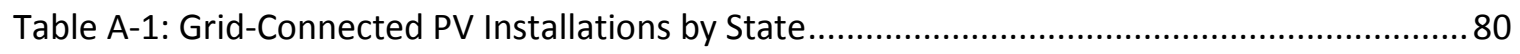




\section{LIST OF FIGURES}

Figure 1-1: Number of Annual Grid-Connected PV Installations (1999-2008) .............................. 2

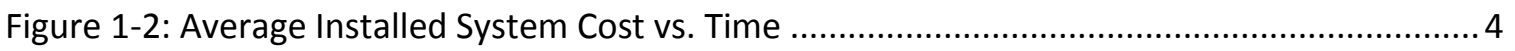

Figure 1-3: Capacity of Annual U.S. Photovoltaic Installations (1999-2008) .................................. 5

Figure 1-4: Annual Installed Grid Connected PV Capacity by Sector (1999-2008) .......................... 5

Figure 1-5: Non-Residential Grid-Connected PV Installations by Capacity (1999-2008) ................ 6

Figure 1-6: Average Capacity of Grid-Connected Residential PV Installations (1999-2008) ........... 6

Figure 1-7: Average Size of Grid-Connected Non-Residential PV Installations (1999-2008)........... 7

Figure 2-1: Average Temperature and Daylight in San Diego, CA .............................................. 10

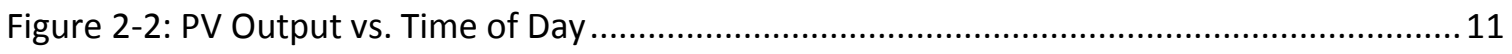

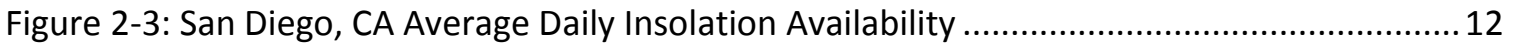

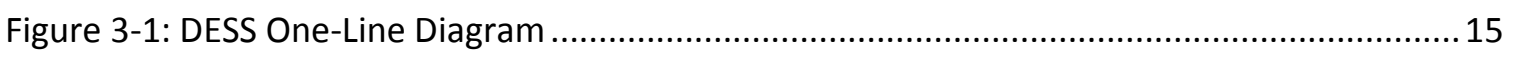

Figure 3-2: Satcon Inverter (left) and Greensmith Energy Management System (Right).............. 16

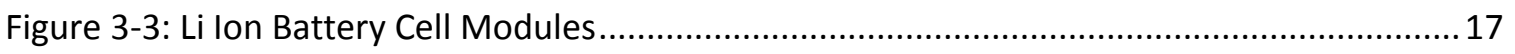

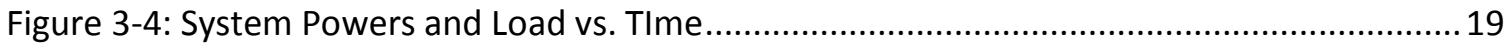

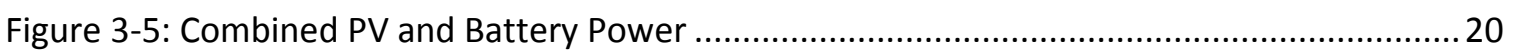

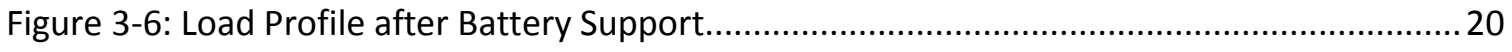

Figure 4-1: PV Array (left), MPPT Controller (middle), Thermal Model (right)..............................23

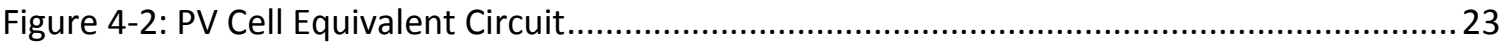

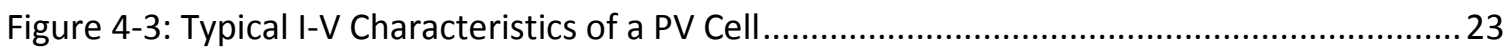

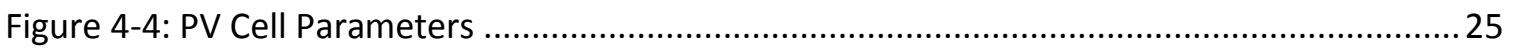

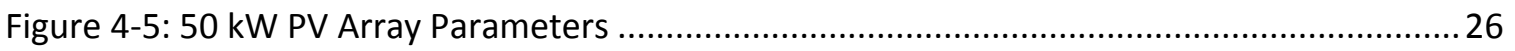

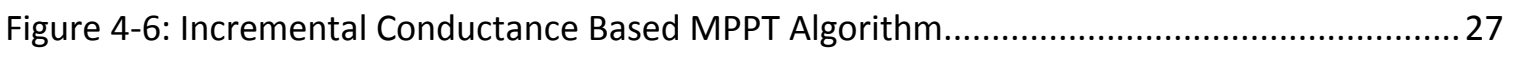

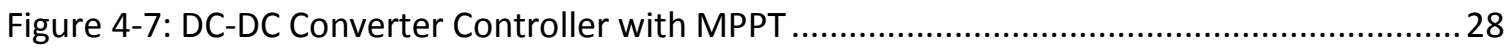

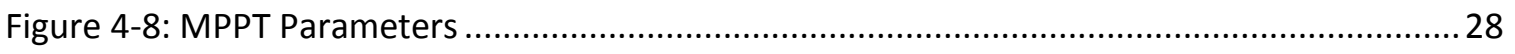

Figure 4-9: MPP Tracking Under Variable Solar Radiation and Temperature Conditions ............. 29

Figure 4-10: Grid Connected PV System .............................................................................. 30

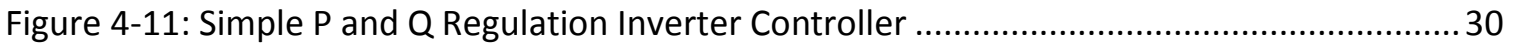

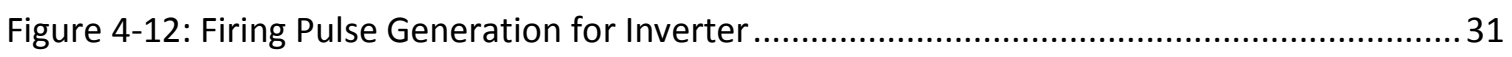

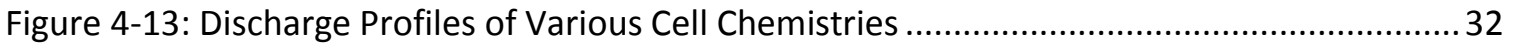

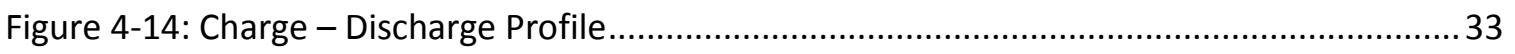

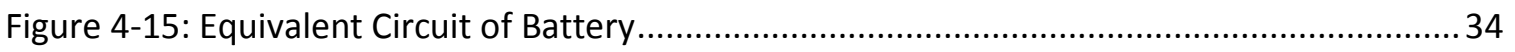

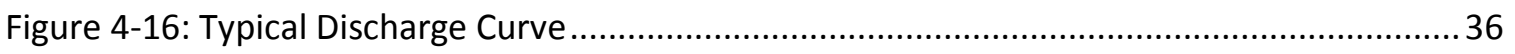

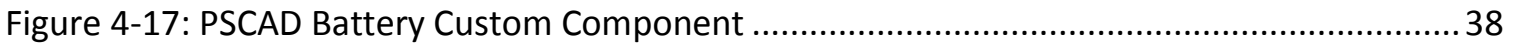

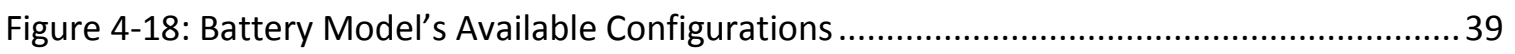

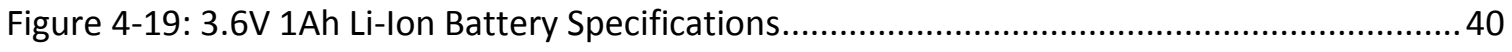

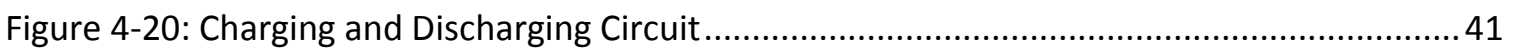

Figure 4-21: Battery Discharge Curves for Different C Rates....................................................... 42

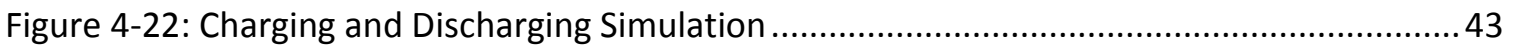

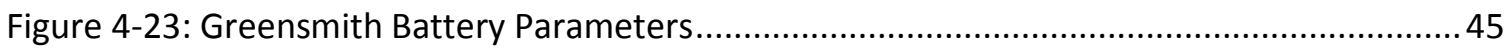




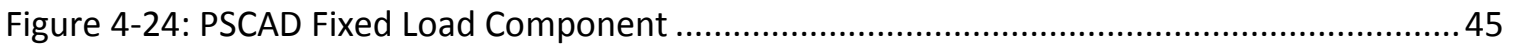

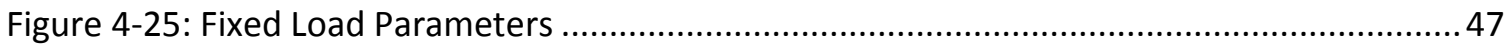

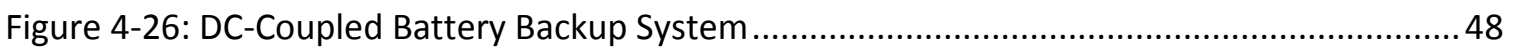

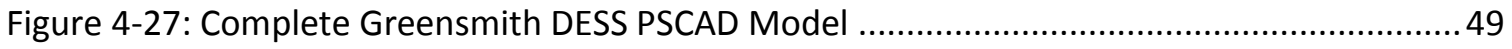

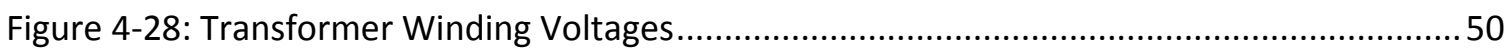

Figure 4-29: Three-Phase Voltage Source Signal Parameters.................................................... 51

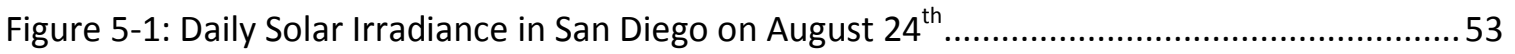

Figure 5-2: Nominal San Diego, CA Insolation on Aug. $24^{\text {th }}$ from 10 A.M. -3 P.M. .......................55

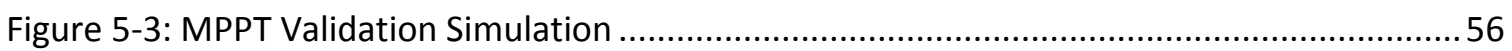

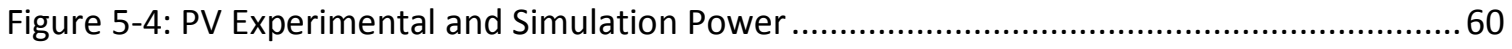

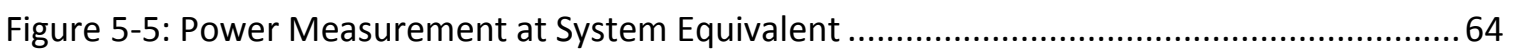

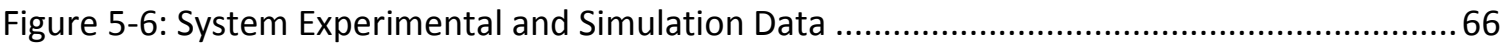

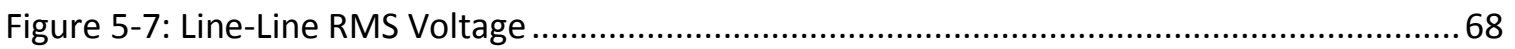

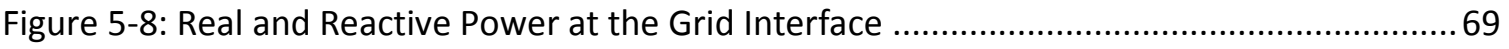

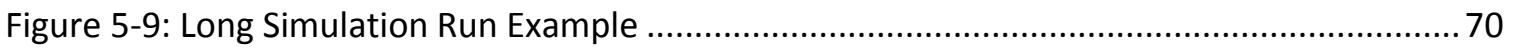

Figure 6-1: Silent Power System at the Energy Innovations Center ............................................ 72

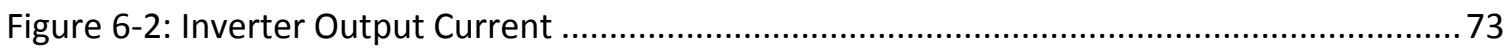

Figure 6-3: Harmonic Spectrum of the Inverter Current (Fundamental 0.28 kA) ........................ 74

Figure 6-4: Harmonic Spectrum of the Voltage (Fundamental $7.43 \mathrm{kV}$ ) ..................................... 74

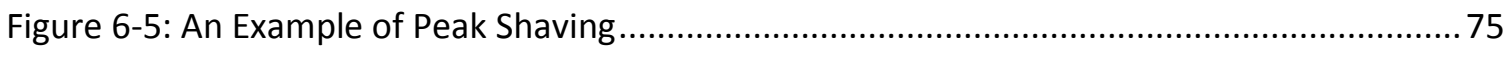

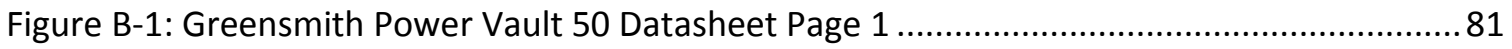

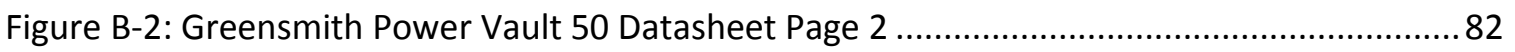

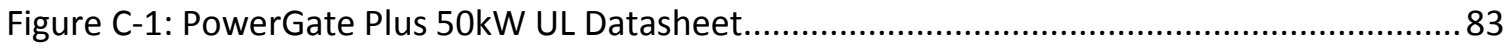

Figure D-1: International Battery IB-B-FHE-160 Datasheet Page 1............................................. 84

Figure D-2: International Battery IB-B-FHE-160 Datasheet Page 2 ............................................. 85 


\section{INTRODUCTION}

This study analyzes a Distributed Energy Storage System's (DESS) ability to supplement a PV system. More specifically, this study examines if DESS's can smooth out the effect of solar intermittency. Solar arrays are prone to intermittent periods of generation due to shading from passing clouds. A battery system can be used to help support the PV array during periods of lost PV power. PSCAD is used to model the DESS, solar system, and electrical load according to the specifications and data that were collected at a real world system.

\subsection{Market Penetration}

Due to the growing demand for renewable energy sources, the manufacturing of solar cells and photovoltaic arrays has advanced considerably in recent years [1]. Starting from a small base, solar panel use has grown to a total global capacity of $40 \mathrm{GW}$ (40,000 MW) at the end of 2010. More than 100 countries use solar PV [2]. Solar photovoltaic installations take on a variety of forms including power stations, buildings, transportation applications, standalone devices, rural electrification, solar roadways, and satellites. One of the most popular forms of PV installations is on the rooftops of homes and buildings. One of the benefits of grid-connected solar electricity is that it can be used locally thus reducing transmission/distribution losses. In 1995 transmission losses in the US were approximately $7.2 \%$ [3]. Figure 1-1 shows the growth in grid-connected PV installations from 1999 to 2008 [4]. Some of the other benefits of solar generation are the environmental benefits and the purchase incentives for homeowners which are discussed next. 


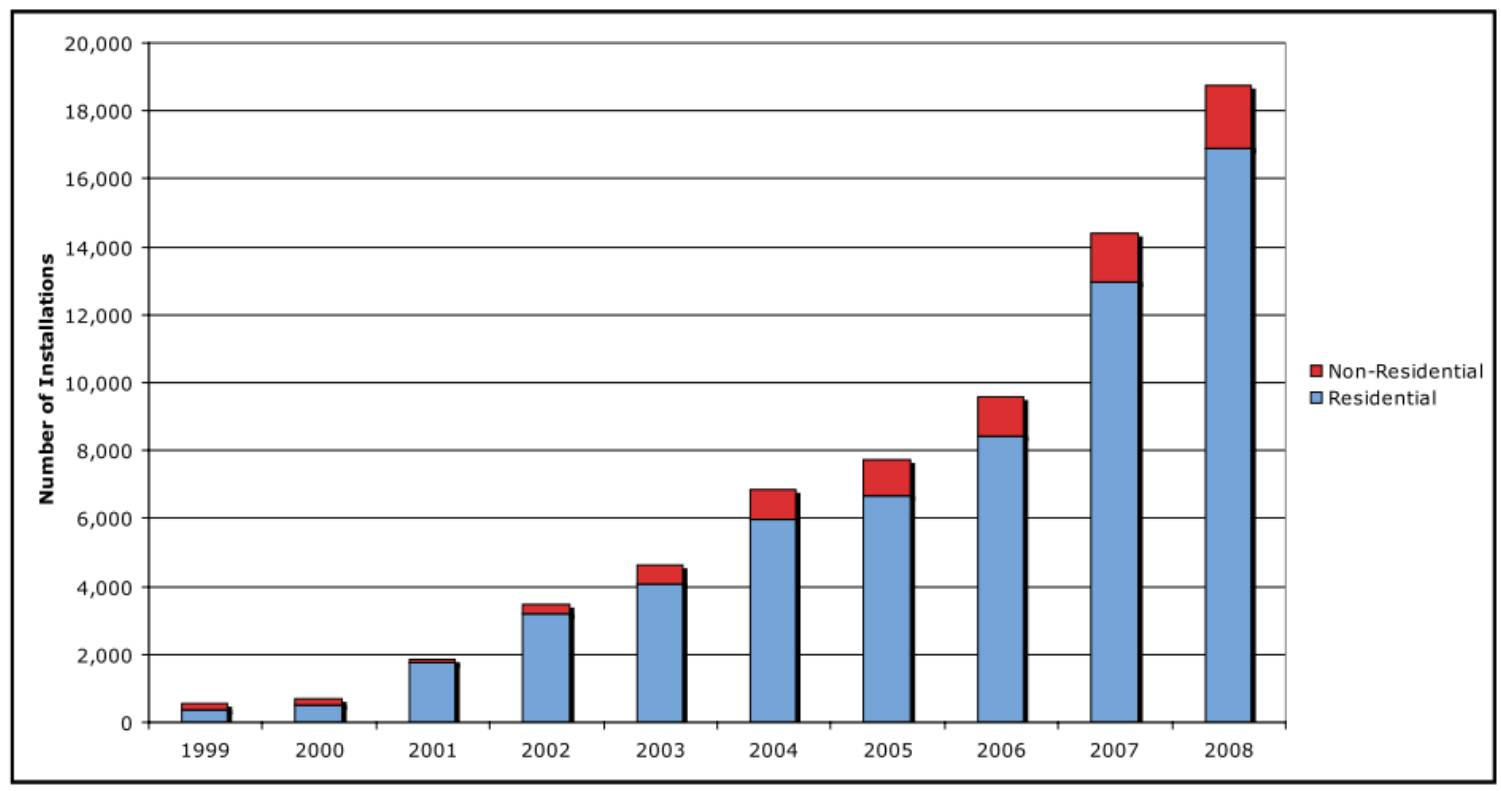

Figure 1-1: Number of Annual Grid-Connected PV Installations (1999-2008)

\subsection{Environmental Benefit}

Solar energy generation is one of the most sustainable ways available of generating energy and electricity today. Solar power systems do not generate air pollution or emissions of any kind during operation. Currently the majority of electricity generated today comes from burning coal. Recently there has been a lot of talk of "clean coal" which is a term used to describe any technology that may reduce the emission of greenhouse gases that develop as a byproduct of burning coal. However, clean coal currently only exists as a concept and, even so, coal is still not a renewable form of energy [5].

Other alternative energy technologies have serious environmental issues. Nuclear energy is controversial due to the fact that the reactors create dangerous nuclear waste. Nuclear waste is accumulating at power plants across the world due to the lack of a longterm storage solution [5]. With nuclear energy there is also the risk of a nuclear reactor meltdown which would have devastating consequences on the people and the 
environment surrounding the facility. The most famous examples of nuclear reactor meltdowns are the Chernobyl disaster of 1986 and more recently with the Fukushima nuclear power plants following the 2011 earthquake in Japan. Generating energy from hydroelectric dams is another example of an alternative energy technology that doesn't result in greenhouse gas emissions, but has a detrimental effect on the ecosystem around the river it interrupts [5].

Solar power generation is a proven technology that is ready for use now. As the solar industry grows, PV systems are becoming increasingly more efficient and affordable. Solar power does not create emissions or any other serious environmental issues. Not only does residential solar generation have benefits for the environment, but it also benefits the home owner.

\subsection{Purchase Incentives}

Under the California Solar Initiative (CSI) California home and business owners can receive cash back for installing solar on their homes or businesses. These cash back incentives combined with the reduction in the utility bill give property owners good reason to install solar panels on their buildings. As a result, California leads the nation in solar energy production. As of January $5^{\text {th }}, 2012$ there are currently 105,467 solar projects in the state of California which combine to generate 1070 megawatts [6]. The cost of installing solar photovoltaic systems is also becoming less expensive. Figure 1-2 shows the trend of average installed system costs over the life of the California Solar Initiative [7]. It can be seen from the graph that the average cost to install a system is steadily declining and is therefore becoming more affordable for homeowners. 


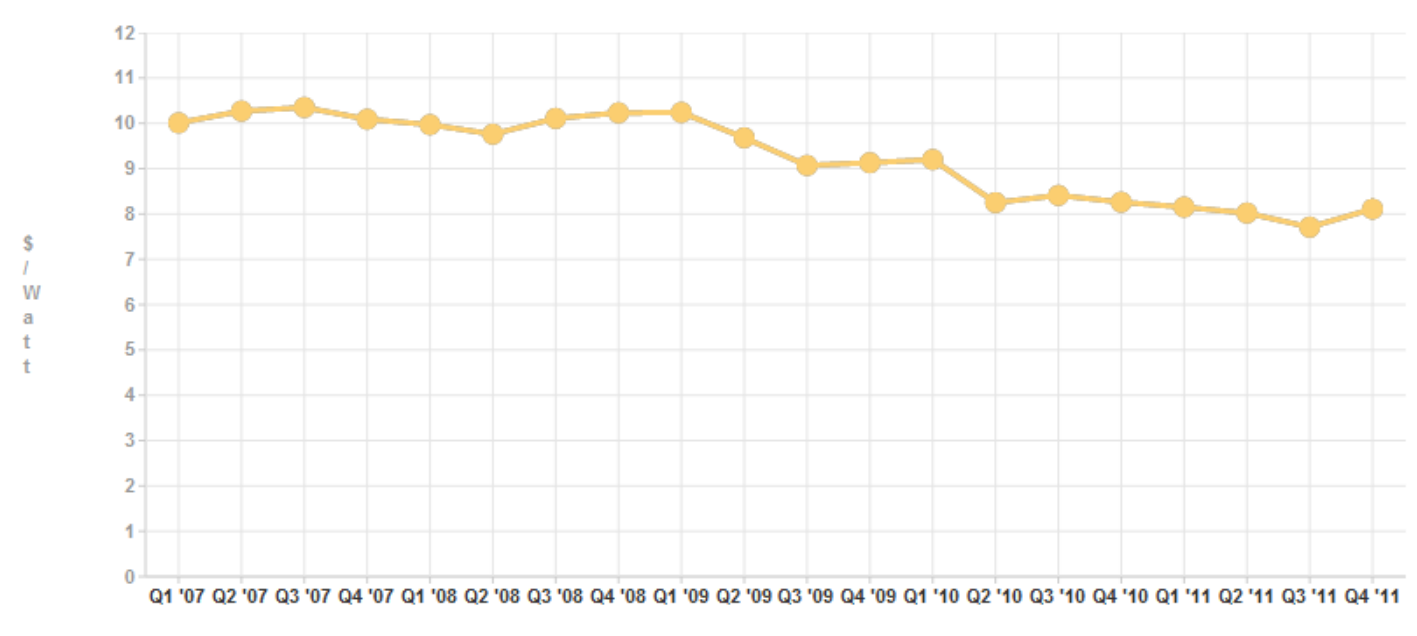

Figure 1-2: Average Installed System Cost vs. Time

\subsection{Capacity}

All of these different factors have contributed to the recent proliferation of solar installations and will certainly result in a greater number of PV installations in the future. Data have shown that the capacity of solar power generation has steadily increased over the past 10 years [4]. Figure 1-3 shows the growth in capacity of annual U.S. photovoltaic installations from 1999 to 2008 in megawatts [4]. Figure 1-4 shows the annual installed grid-connected PV capacity from 1999 to 2008 broken down by sectors [4]. Finally, Figure 1-5 shows the increase in non-residential grid-connected PV installations broken down by capacities of greater or less than 500kW [4]. 


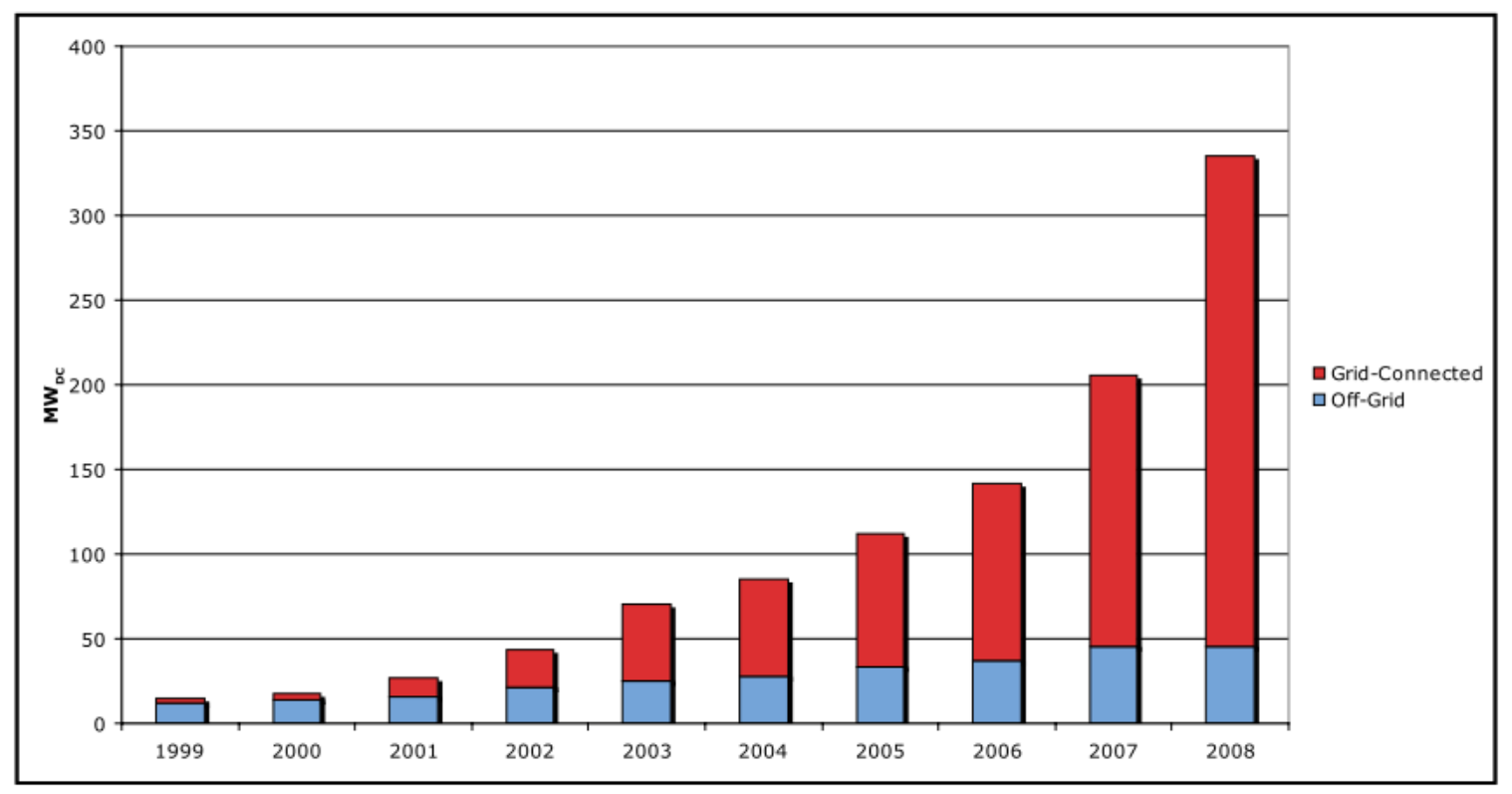

Figure 1-3: Capacity of Annual U.S. Photovoltaic Installations (1999-2008)

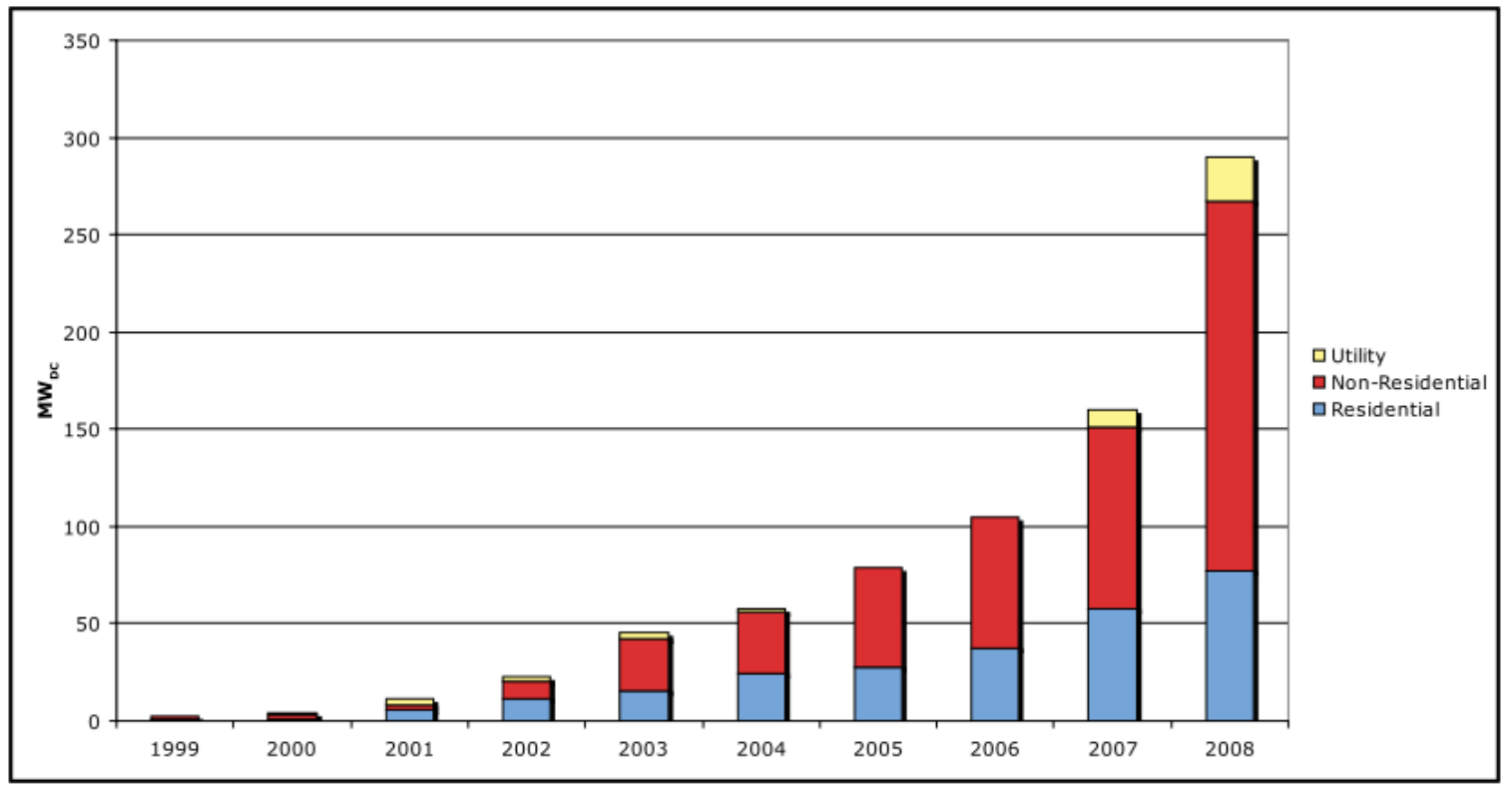

Figure 1-4: Annual Installed Grid Connected PV Capacity by Sector (1999-2008) 


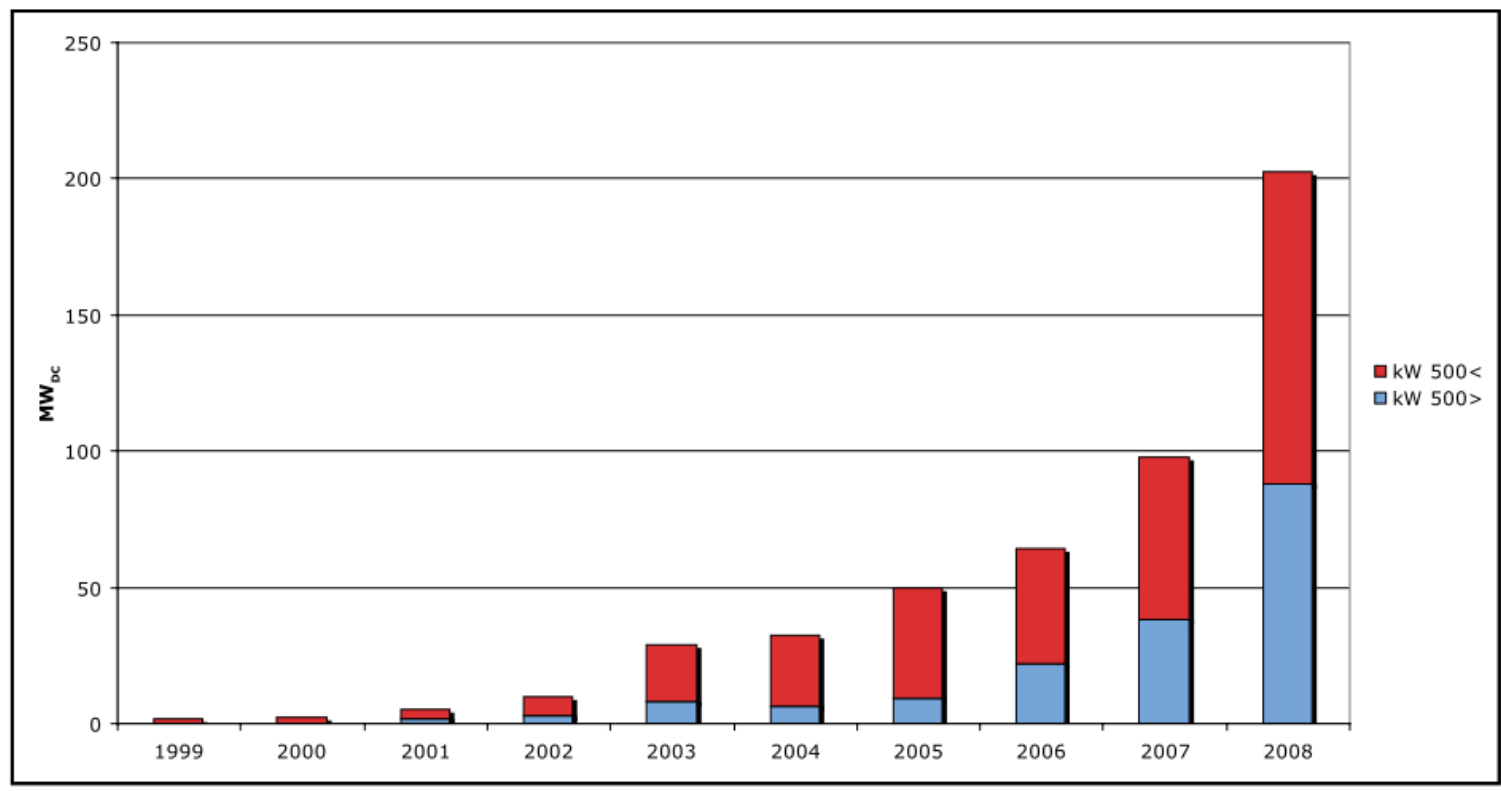

Figure 1-5: Non-Residential Grid-Connected PV Installations by Capacity (1999-2008)

Figure 1-6 shows the average capacity of grid-connected residential PV installations from 1999 to 2008 while Figure 1-7 shows the average size of gridconnected non-residential PV installations from 1999 to 2008 [4]. Both graphs show an increase in PV installations' average capacity.

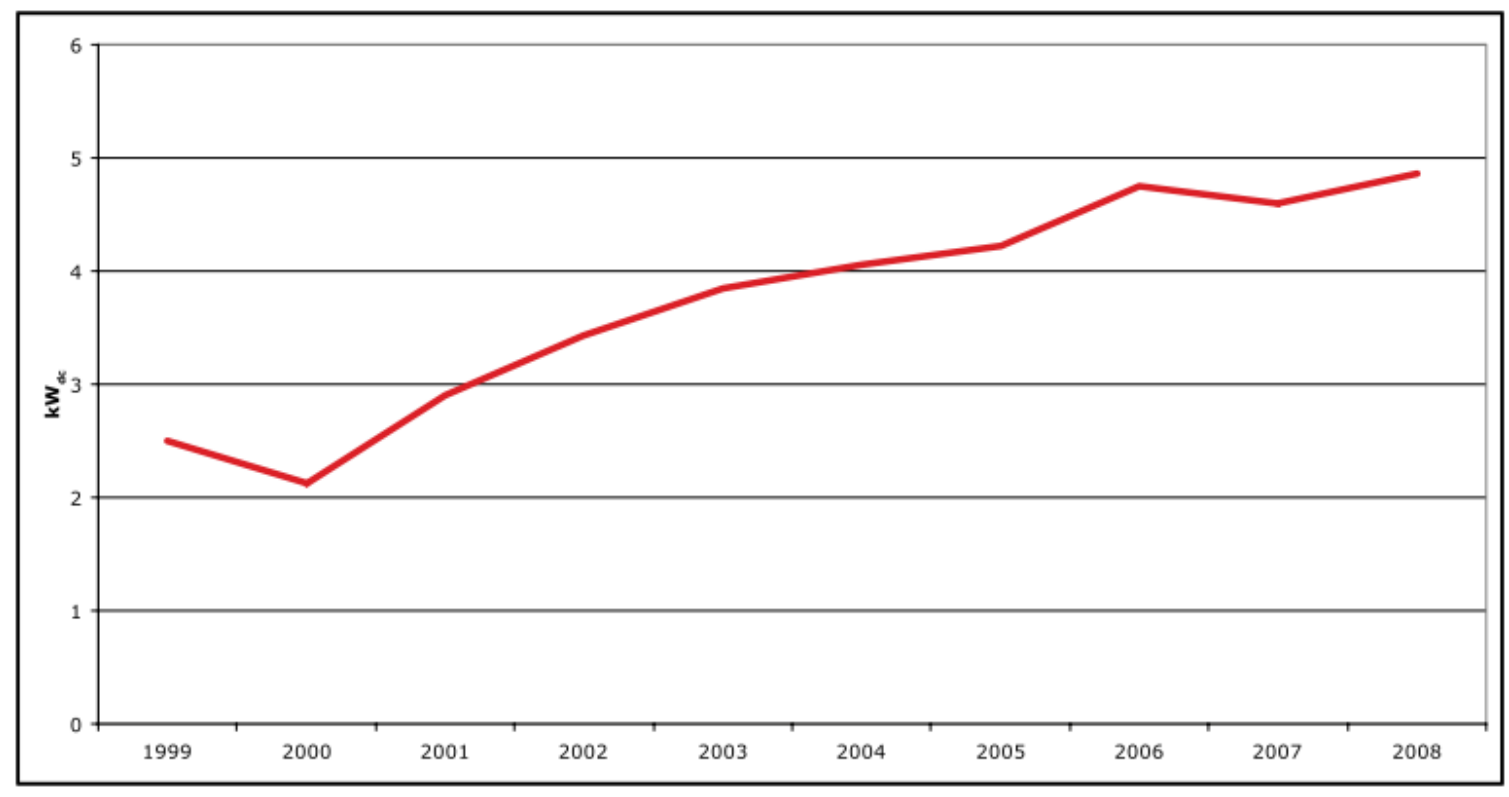

Figure 1-6: Average Capacity of Grid-Connected Residential PV Installations (1999-2008) 


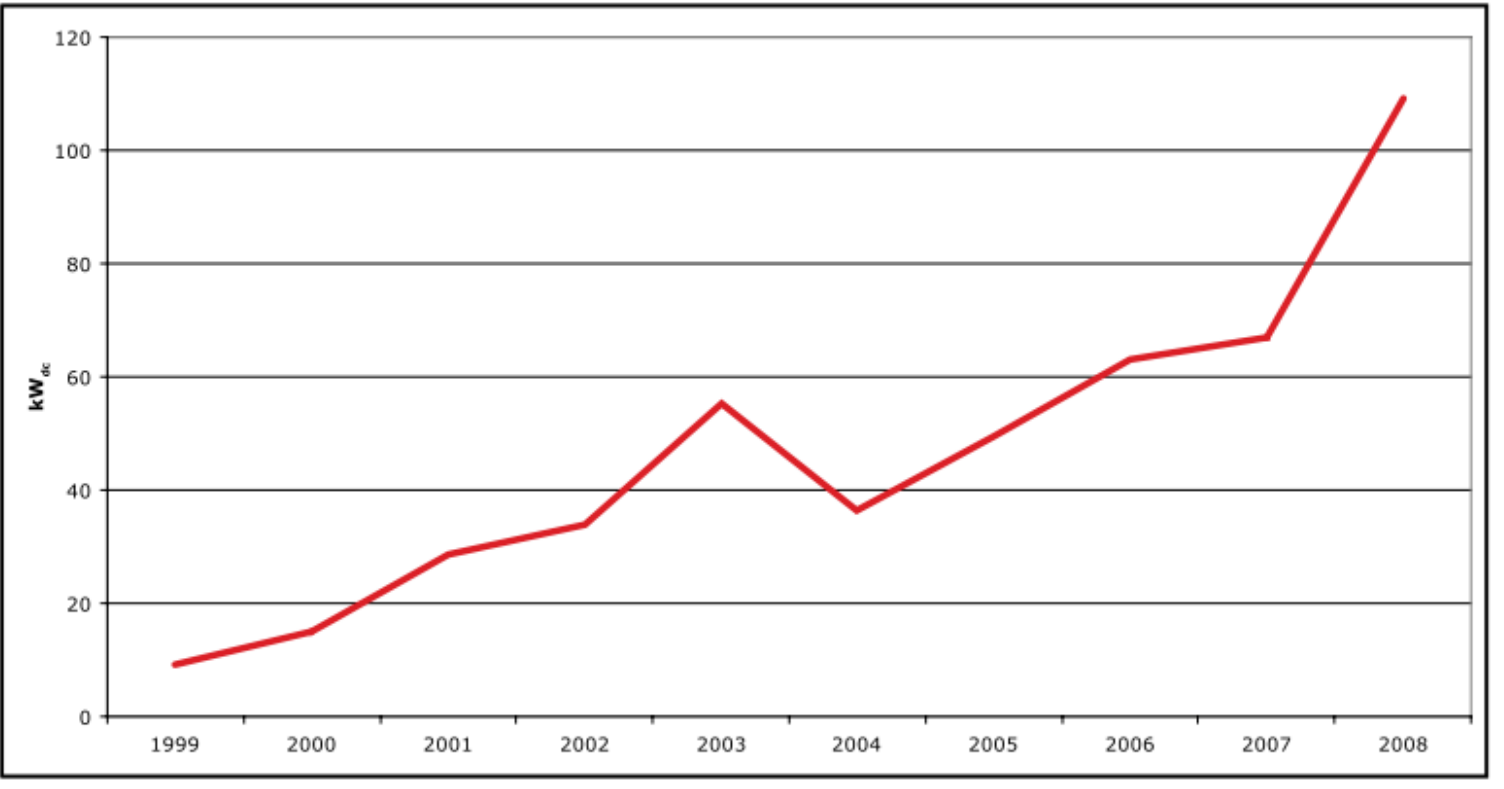

Figure 1-7: Average Size of Grid-Connected Non-Residential PV Installations (1999-2008)

Within the U.S., the state of California is a leader in the solar power movement.

Table 1-1 ranks the U.S. states by their 2008 solar capacity [4]. California is far and away the leader of solar capacity within the U.S. with $62 \%$ of the market share in 2008 . California's 178.7 MW of solar generation in 2008 was much more than second place New Jersey’s 22.5 MW. Also, California had one of the largest increases in capacity from 91.8 MW to 178.7 MW (95\% increase) from 2007 to 2008. Table 1-2 shows that $67 \%$ of all PV capacity installed in 2008 were in California [4]. Finally, Table 1-3 shows that California is also the leader in per capita solar capacity [4]. The complete table of Grid-Connected PV Installations by State is in Appendix A. California has always been one of the most progressive states in the U.S. and that shows with its strong adoption of solar energy. The solar capacity in California is projected to continue increasing with new PV installations in the future. On April 12 $2^{\text {th }}, 2011$ Governor Jerry Brown signed California's Renewable Portfolio Standard (RPS) into law. The legislation will require all of California's utilities to source 33 percent of their overall electrical generation from 
renewable sources by the year 2020 [8]. In order to reach this goal, utilities will have to invest in various renewables including solar.

Table 1-1: Top Ten States by 2008 Capacity

\begin{tabular}{|l|r|r|r|r|r|}
$\begin{array}{r}\text { 2008 Rank by } \\
\text { State }\end{array}$ & $\begin{array}{r}\mathbf{2 0 0 8} \\
(\mathbf{M W})\end{array}$ & $\begin{array}{r}\mathbf{2 0 0 7} \\
(\mathbf{M W})\end{array}$ & $\begin{array}{r}\mathbf{0 7 - 0 8} \\
\text { \% change }\end{array}$ & $\begin{array}{r}\mathbf{2 0 0 8} \\
\text { Market } \\
\text { Share }\end{array}$ & $\begin{array}{r}\mathbf{2 0 0 7} \\
\text { Rank }\end{array}$ \\
\hline 1. California & 178.7 & 91.8 & $95 \%$ & $62 \%$ & 1 \\
\hline 2. New Jersey & 22.5 & 20.4 & $10 \%$ & $8 \%$ & 2 \\
\hline 3. Colorado & 21.7 & 11.5 & $88 \%$ & $7 \%$ & 4 \\
\hline 4. Nevada & 14.9 & 15.9 & $-6 \%$ & $5 \%$ & 3 \\
\hline 5. Hawaii & 8.6 & 2.9 & $200 \%$ & $3 \%$ & 6 \\
\hline 6. New York & 7.0 & 3.8 & $85 \%$ & $2 \%$ & 5 \\
\hline 7. Arizona & 6.4 & 2.8 & $129 \%$ & $2 \%$ & 7 \\
\hline 8. Connecticut & 5.3 & 2.5 & $109 \%$ & $2 \%$ & 8 \\
\hline 9. Oregon & 4.8 & 1.1 & $330 \%$ & $2 \%$ & 11 \\
\hline 10. North Carolina & 4.0 & 0.4 & $899 \%$ & $1 \%$ & 16 \\
\hline All Other States & 15.9 & 7.2 & $122 \%$ & $5 \%$ & \\
\hline Total & 289.8 & 160.3 & $81 \%$ & & \\
\hline
\end{tabular}

Table 1-2: Top Ten States by Cumulative Capacity

\begin{tabular}{|l|r|r|} 
& MW $_{\text {DC }}$ & $\begin{array}{r}\text { Market } \\
\text { Share }\end{array}$ \\
\hline 1. California & 528 & $67 \%$ \\
\hline 2. New Jersey & 70 & $9 \%$ \\
\hline 3. Colorado & 36 & $5 \%$ \\
\hline 4. Nevada & 34 & $4 \%$ \\
\hline 5. Arizona & 25 & $3 \%$ \\
\hline 6. New York & 22 & $3 \%$ \\
\hline 7. Hawaii & 14 & $2 \%$ \\
\hline 8. Connecticut & 9 & $1 \%$ \\
\hline 9. Oregon & 8 & $1 \%$ \\
\hline 10. Massachusetts & 8 & $1 \%$ \\
\hline All Other States & 39 & $5 \%$ \\
\hline Total & 792 & \\
\hline
\end{tabular}

Table 1-3: Top Ten States by Per Capita Capacity

\begin{tabular}{|l|c|c} 
& $\begin{array}{c}\text { Cumulative } \\
\text { through 2008 } \\
\left(\mathbf{W}_{\mathrm{DC}} / \mathbf{p e r s o n}\right)\end{array}$ & $\begin{array}{c}\mathbf{2 0 0 8} \\
\text { Installations } \\
\left(\mathbf{W}_{\mathrm{DC}} \text { person }\right)\end{array}$ \\
\hline 1. California & 14.6 & 4.9 \\
\hline 2. Nevada & 14.2 & 6.7 \\
\hline 3. Hawaii & 10.6 & 6.2 \\
\hline 4. New Jersey & 8.1 & 2.6 \\
\hline 5. Colorado & 7.7 & 4.6 \\
\hline 6. Arizona & 4.3 & 1.1 \\
\hline 7. Connecticut & 2.5 & 1.5 \\
\hline 8. Delaware & 2.2 & 0.7 \\
\hline 9. Oregon & 2.1 & 1.3 \\
\hline 10. Vermont & 1.8 & 0.6 \\
\hline National Average & 2.7 & 1.0 \\
\hline
\end{tabular}




\section{THE CHALLENGE}

Solar arrays are a fairly simple source of direct energy generation. A basic residential solar set up has the arrays mounted on the roof of the house. The power is then regulated using a DC-DC converter and then converted to AC power using an inverter. However, there are some unique challenges that exist with the use of solar energy. As solar installations continue to increase, these challenges have the potential for widespread impact.

\section{$2.1 \quad$ Weather Effect}

The effects of Mother Nature play a part in the performance of PV systems. Insolation and temperature are two of the main factors that determine solar generation. Throughout a year, every city experiences a change in seasons which corresponds to changes in average temperature and insolation. Figure 2-1 shows the change in temperature and the amount of daylight that is available throughout a year in San Diego, CA [9]. Temperature peaks in the summer time and is the lowest in the winter time. The maximum amount of daylight that is available is around June or July while the lowest amount of daylight available during the year is around November or December. These differences in temperature and daylight affect the solar cell's power output and that can present a challenge. 


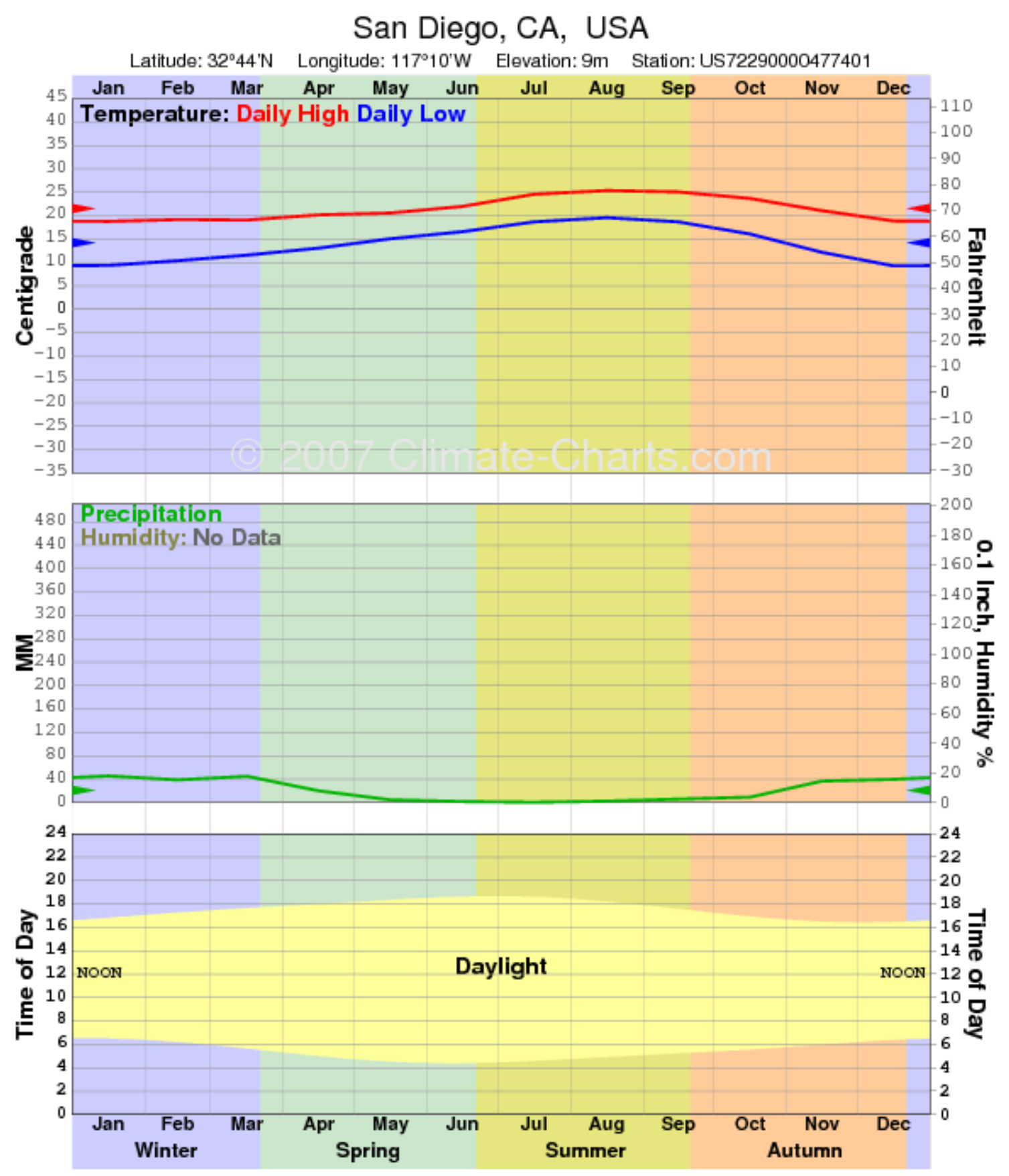

Figure 2-1: Average Temperature and Daylight in San Diego, CA

\subsection{Solar Intermittency}

One of the biggest issues associated with solar panels is their high variability in generation throughout the course of a day. If a PV array is subject to shading from 
clouds, buildings, or trees it will see a drop in power generation. Figure 2-1 shows the PV array power output of a 4.6 MW system in Springerville, Arizona for one day. This is one of the largest existing U.S. arrays [10].

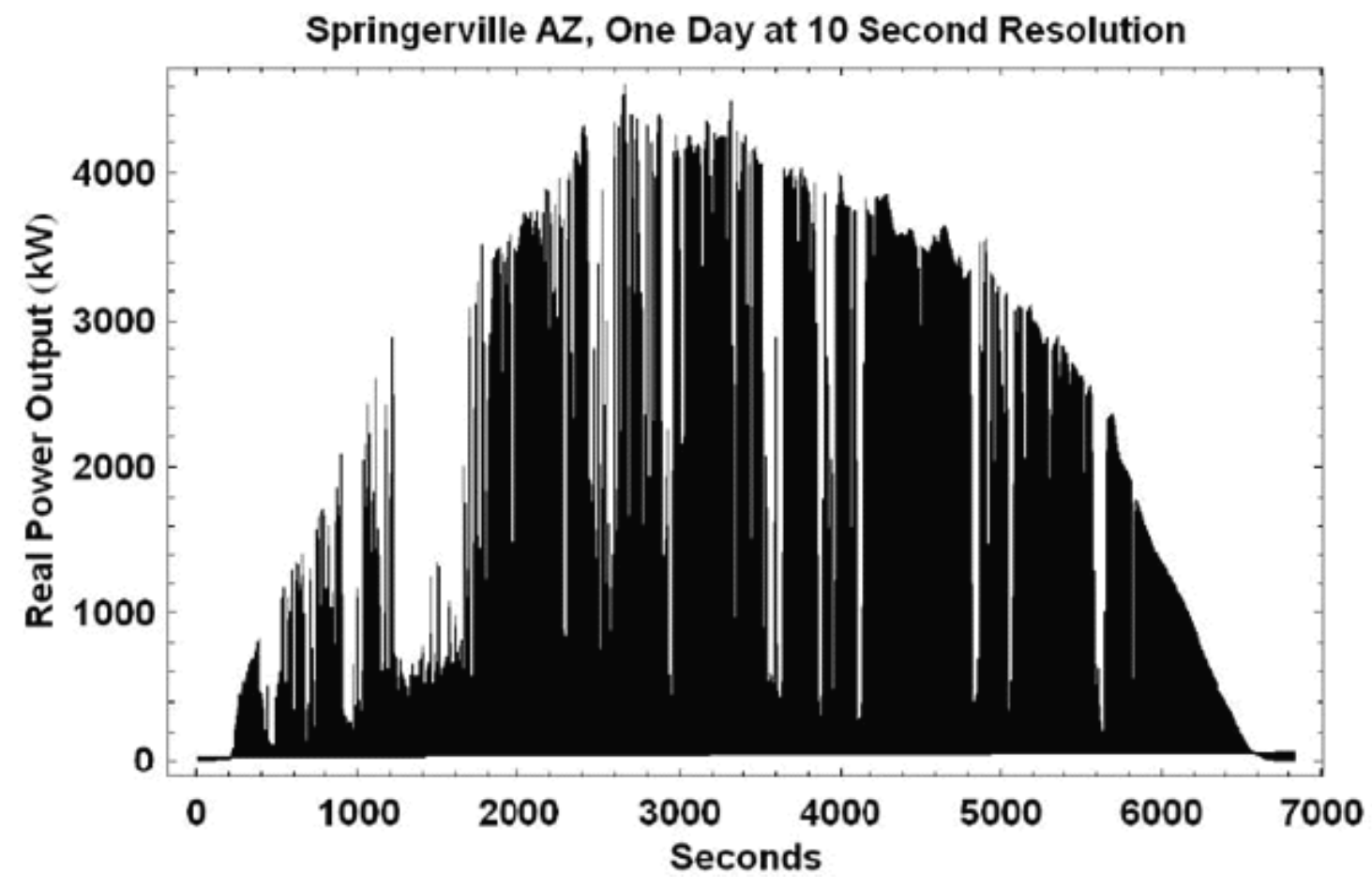

Figure 2-2: PV Output vs. Time of Day

It can be seen from the figure that the PV output experiences periods of intermittency throughout the day most likely due to shading. The challenge with intermittent renewables is that they have unpredictable outputs that can cause system instability and unreliability [10]. One of the ways to remedy this problem is to use a Distributed Energy Storage System (DESS) in tandem with a PV array.

\subsection{Maximizing PV Power}

There are a couple different methods used to boost the power output of a PV array over the course of a day. One method is to use a solar tracking system. A solar tracker is 
a system that orients the array panels towards the sun. As opposed to a fixed-mounted solar panel array, a solar tracker system has its solar panels mounted on a motorized system. The goal is to capture the most amount of direct beam from the sun and this is achieved by making the sun as visible to the panel for as long as possible. Figure 2-3 is a chart of the average daily insolation availability each month in San Diego, CA [11]. It can be seen from the graph that the 1-Axis North South Tracking Array always has more average daily insolation than its Fixed Array counterpart regardless of time of year or latitude tilt. An even greater improvement is Two Axis Tracking which allows for WestEast tracking in addition to North-South tracking. The last row of Figure 2-3 shows that Two Axis Tracking produces even more average daily insolation than the 1-Axis North South Tracking Array [11].

\section{SAN DIEGO, CALFORNIA
AVERAGE DAILY INSOLATION AVAILABILITY $\left(\mathrm{KWH} / \mathrm{M}^{2}\right)$}

LOCATION: $32^{\circ} 44^{\prime} \mathrm{N}, 117^{\circ} 10^{\prime} \mathrm{W}, 9$ Meters

\begin{tabular}{|c|c|c|c|c|c|c|c|c|c|c|c|c|c|}
\hline & JAN & FEB & MAR & APR & MAY & JUN & JUL & $A \cup G$ & SEP & OCT & NOV & DEC & YR \\
\hline \multicolumn{14}{|l|}{ LATITUDE TILT -15( $\left(^{\circ}\right)$} \\
\hline Fixed Array & 4.06 & 5.07 & 5.87 & 6.45 & 6.33 & 6.18 & 6.85 & 6.94 & 5.93 & 5.33 & 4.41 & 3.85 & 5.61 \\
\hline $\begin{array}{l}\text { 1-Axis North South } \\
\text { Tracking Array }\end{array}$ & 5.28 & 6.58 & 7.93 & 8.57 & 8.10 & 7.77 & 8.83 & 8.91 & 7.46 & 6.80 & 5.60 & 4.90 & 7.23 \\
\hline \multicolumn{14}{|l|}{ LATITUDE TILT $\left({ }^{\circ}\right)$} \\
\hline Fixed Array & 4.73 & 5.66 & 6.21 & 6.42 & 6.02 & 5.76 & 6.43 & 6.80 & 6.10 & 5.84 & 5.06 & 4.54 & 5.80 \\
\hline $\begin{array}{l}\text { 1-Axis North South } \\
\text { Tracking Array }\end{array}$ & 5.79 & 7.03 & 8.18 & 8.55 & 7.89 & 7.48 & 8.54 & 8.81 & 7.59 & 7.20 & 6.11 & 5.45 & 7.39 \\
\hline \multicolumn{14}{|l|}{ LATITUDE TILT + $15\left({ }^{\circ}\right)$} \\
\hline Fixed Array & 5.12 & 5.93 & 6.21 & 6.06 & 5.42 & 5.07 & 5.70 & 6.29 & 5.94 & 6.03 & 5.43 & 4.98 & 5.68 \\
\hline $\begin{array}{l}\text { 1-Axis North South } \\
\text { Tracking Array }\end{array}$ & 6.09 & 7.23 & 8.16 & 8.28 & 7.47 & 6.99 & 8.02 & 8.44 & 7.46 & 7.33 & 6.39 & 5.79 & 7.31 \\
\hline TWO AXIS TRACKING & 6.16 & 7.22 & 8.20 & 8.61 & 8.16 & 7.92 & 8.94 & 8.94 & 7.59 & 7.32 & 6.43 & 5.90 & 7.62 \\
\hline
\end{tabular}

Figure 2-3: San Diego, CA Average Daily Insolation Availability 
Another way of maximizing PV power is to make use of Maximum Power Point Tracking (MPPT). A MPPT is a control system that increases PV power by operating solar cells at the knee of their I-V curves. The knee point is where the current and voltage of the solar cell are both at their max. Increasing either current or voltage increase power through electrical power's $\mathrm{P}=\mathrm{IV}$ characteristic. The MPPT is usually integrated into the DC-DC converter's control system. MPPT's are discussed further in section 4.3. 


\subsection{The Complete System}

Installed at the SDG\&E Skills Training Center is one of the first advanced energy storage systems in California. The system is owned by the Electric Power Research Institute (EPRI) and is on loan to SDG\&E for testing. The system integrator is Greensmith Energy Management who is also the manufacturers of the Greensmith Distributed Energy Storage Unit. Since this is one of the first systems of its kind to be installed, every step of the process is being documented for posterity. Documentation includes any lessons learned during the shipping, receiving, or installation process as well as system operating experience including event programming and equipment monitoring.

The system is currently on an 18 month testing program where all its various modes of operation will be exercised. Some of its operation modes include constant power charge/discharge, peak shaving, and PV smoothing/load following. During this period the engineers will also perform tests to make sure that the system complies with IEEE 1547 standards. The datasheet of a Greensmith Power Vault 50 is in Appendix B. Figure 3-1 shows the one-line diagram of the DESS. 


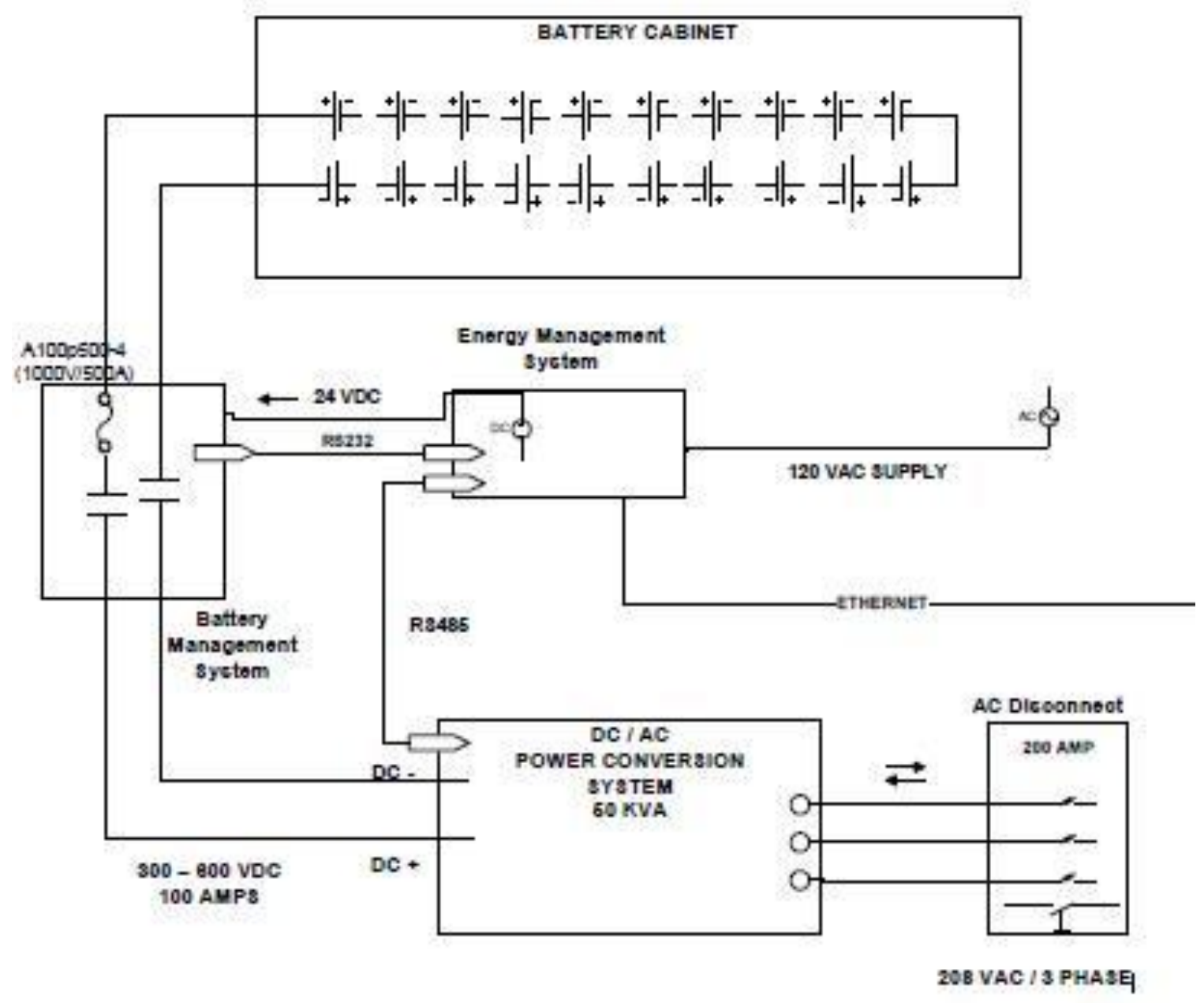

Figure 3-1: DESS One-Line Diagram

\subsection{The Inverter}

The inverter in this system is based on a Satcon PowerGate Plus 50kW UL (PVS50-UL). It is a three-phase inverter rated at 50kW and 120/208 VAC. The system makes use of a Maximum Power Point Tracking (MPPT) system to boost the PV's yield. It has been modified by Satcon to offer full four quadrant power capability which allows it to deliver both real and reactive power. This feature is not available in any off-the-shelf Satcon inverters. The datasheet of the similarly sized Satcon PowerGate Plus 50kW UL 
(PVS-50-UL) inverter is in Appendix C. The cabinet on the left in Figure 3-2 is the actual Satcon inverter of this system.

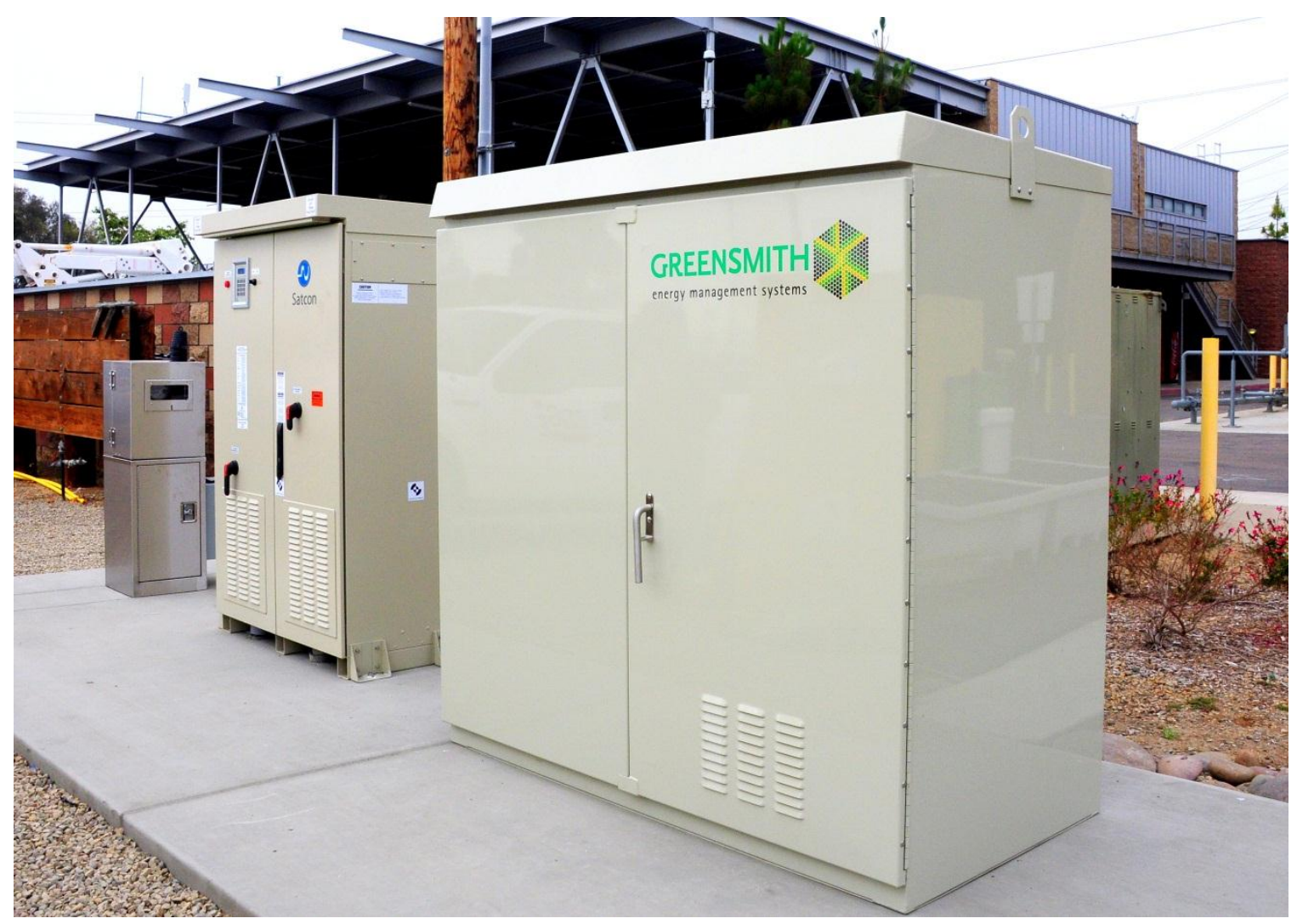

Figure 3-2: Satcon Inverter (left) and Greensmith Energy Management System (Right)

\subsection{The Battery Management System}

On the right in Figure 3-2 is the cabinet of the Greensmith energy management system. The cabinet houses the batteries as well as the batteries' management system. The Greensmith system allows for real-time battery module measurements of voltage, current, temperature, cell capacity, State of Charge (SOC), efficiency, and State of Health $(\mathrm{SOH})$. It also has a system that will keep the cells balanced and it will protect the batteries from under/over-voltage, temperature, and over current. The system also allows 
the user to have control over the batteries operation including dynamic, real-time power control.

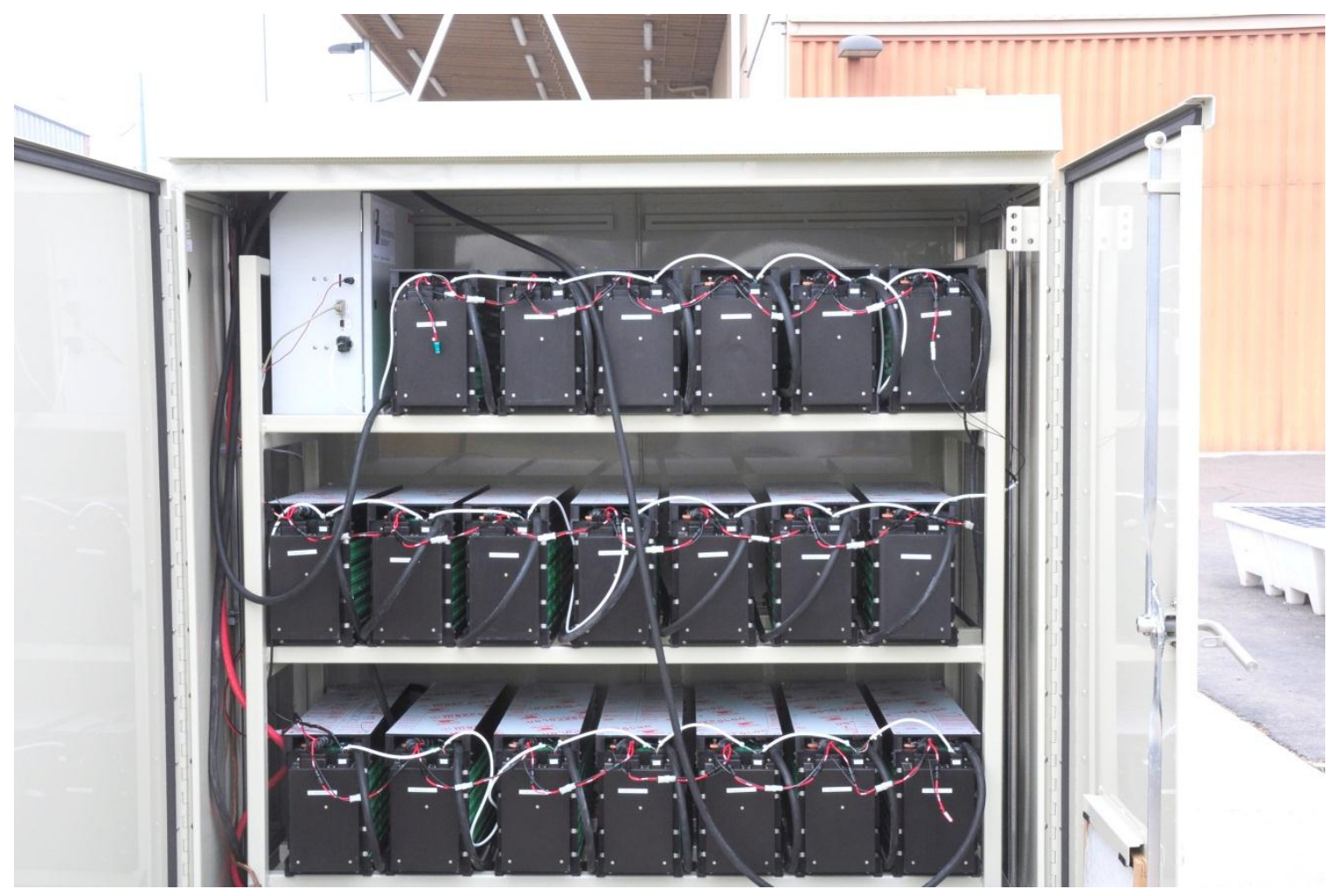

Figure 3-3: Li Ion Battery Cell Modules

\subsection{The Batteries}

Figure 3-3 is a picture of the inside of the Greensmith cabinet. The complete battery module consists of 20 battery packs in series. The batteries being used are Lithium Iron Phosphate (Li-Ion) and are manufactured by International Battery. Each of the 20 battery packs is made up of eight IB-B-FHE-160 packaged cells. In total there are 160 rechargeable battery cells in series. Each of the IB-B-FHE-160 packaged cells has a nominal voltage of $3.2 \mathrm{~V}$ and capacity of $160 \mathrm{Ah}$. The datasheet of the International Battery IB-B-FHE-160 packaged cell is in Appendix D. When put in series, these cells 
combine for a total battery system voltage of $512 \mathrm{~V}$ and capacity of $82 \mathrm{kWh}$. The complete overall battery ratings are $50 \mathrm{~kW}, 82 \mathrm{kWh}$, and $512 \mathrm{VDC}$.

\subsection{Test Data}

Since installation, SDG\&E has collected data on the performance of the DESS under various test cases. One of the modes of operation tested was the DESS's ability to smooth intermittent PV generation. The SDG\&E Skills Training Center has a small solar setup of approximately $12 \mathrm{kVA}$, but it is not directly tied to the battery and is instead coupled at the secondary of the transformer. Because it is a research setup, the availability of the solar array is very intermittent and it is often not functioning or turned off. Instead of using data from the PV array, simulated PV data was entered into the battery controller for testing purposes. The test took place on August, $24^{\text {th }}, 2011$ from the hours of 10:00 A.M. to 3:00 P.M. Since the Skills Training Center is a commercial business building, this time period is when the building is most active during the day. It is also the time when the sun is the closest to the Earth and is therefore the time when the most PV generation is occurring. Data is collected at every minute during that time frame for the battery's SOC, voltage, temperature, instantaneous power, DC current, etc. Some of the results of the test can be seen in Figure 3-4 below. 


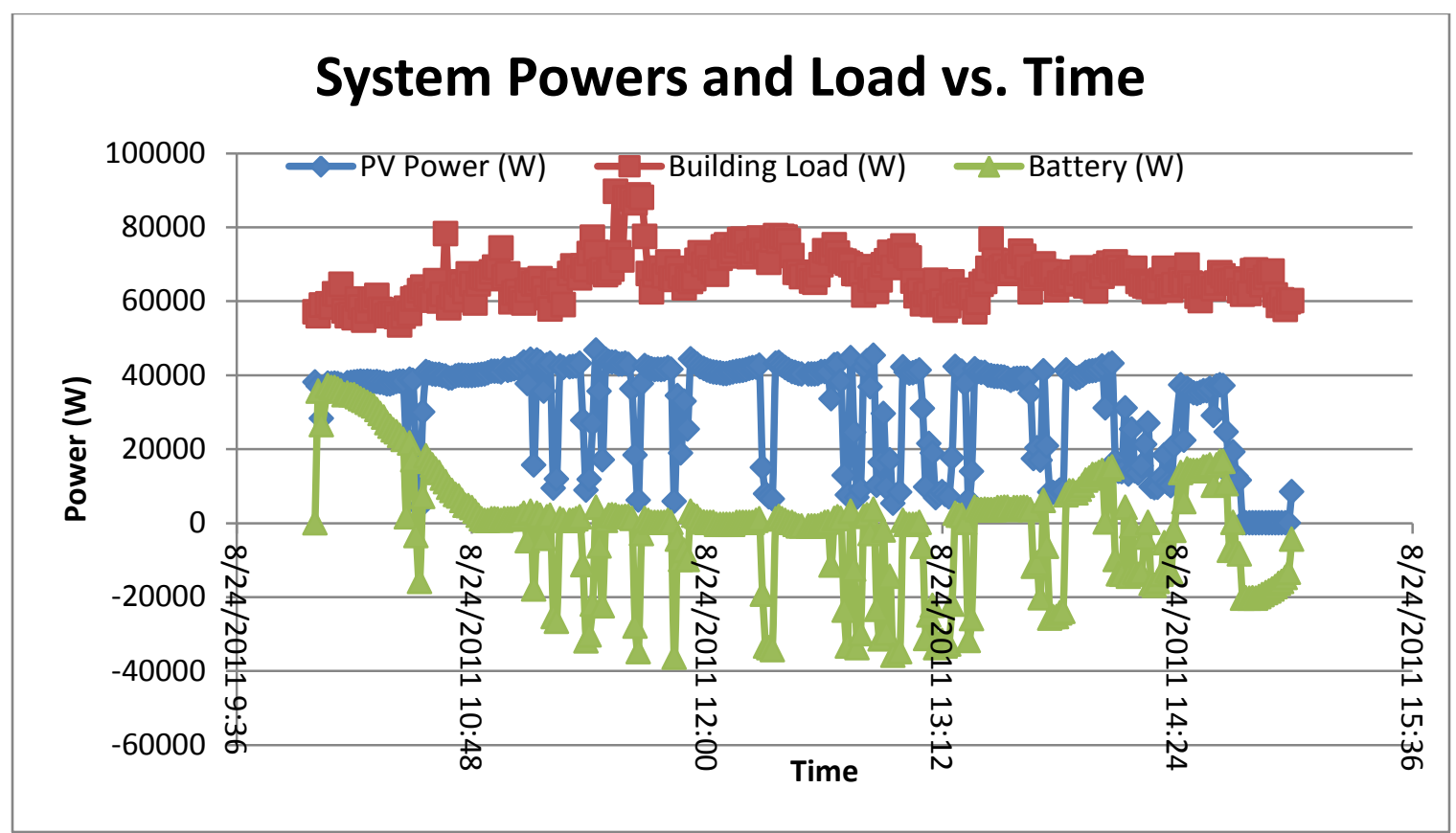

Figure 3-4: System Powers and Load vs. TIme

In Figure 3-4 it can be seen that the building load does not fluctuate much over time. The building has an average load of about $66479 \mathrm{~W}$ during this time frame. The PV output power on the other hand fluctuates greatly at certain points. The simulated PV power data is based on a $50 \mathrm{~kW}$ array. The periods of power drop are most likely due to shading from passing clouds. Otherwise the PV array produces an instantaneous power of about $40 \mathrm{~kW}$ during this period. The last plot on Figure 3-4 is of the battery's power. Positive values correspond to the battery charging and negative values correspond to the battery discharging. When compared with the PV's power, it can be seen that the battery closely follows the power output of the PV. More specifically, when the PV experiences periods of intermittency, the battery discharges power to make up for the momentary loss of PV power. If the PV is providing uninhibited power, the battery charges in order to be ready for new periods of intermittency. Figure 3-5 below is a plot of the combined PV and battery power over time. 


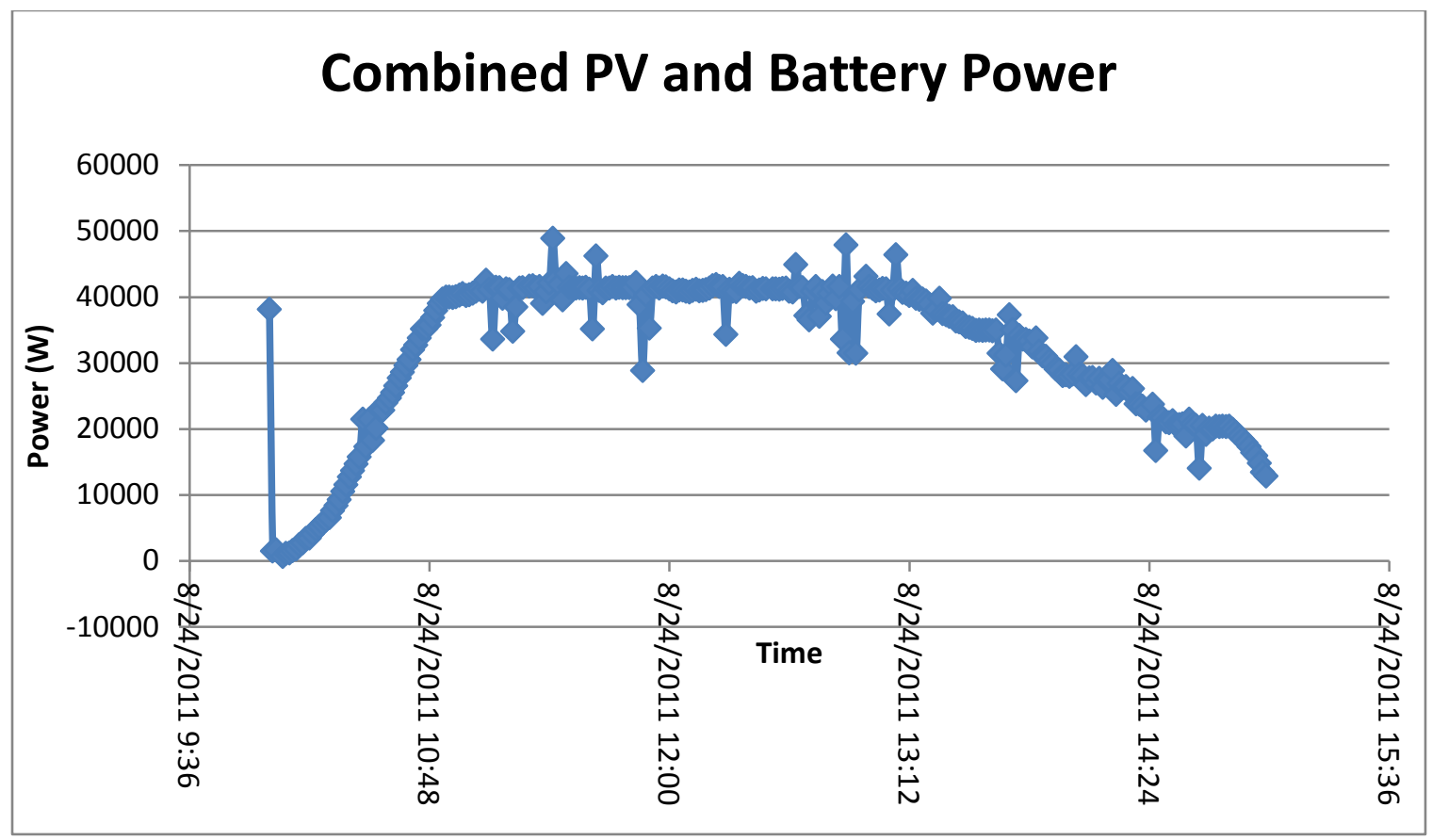

Figure 3-5: Combined PV and Battery Power

Figure 3-5 shows how the battery is able to smooth out the variability in the solar generation at every point. This result is also shown in Figure 3-5 below.

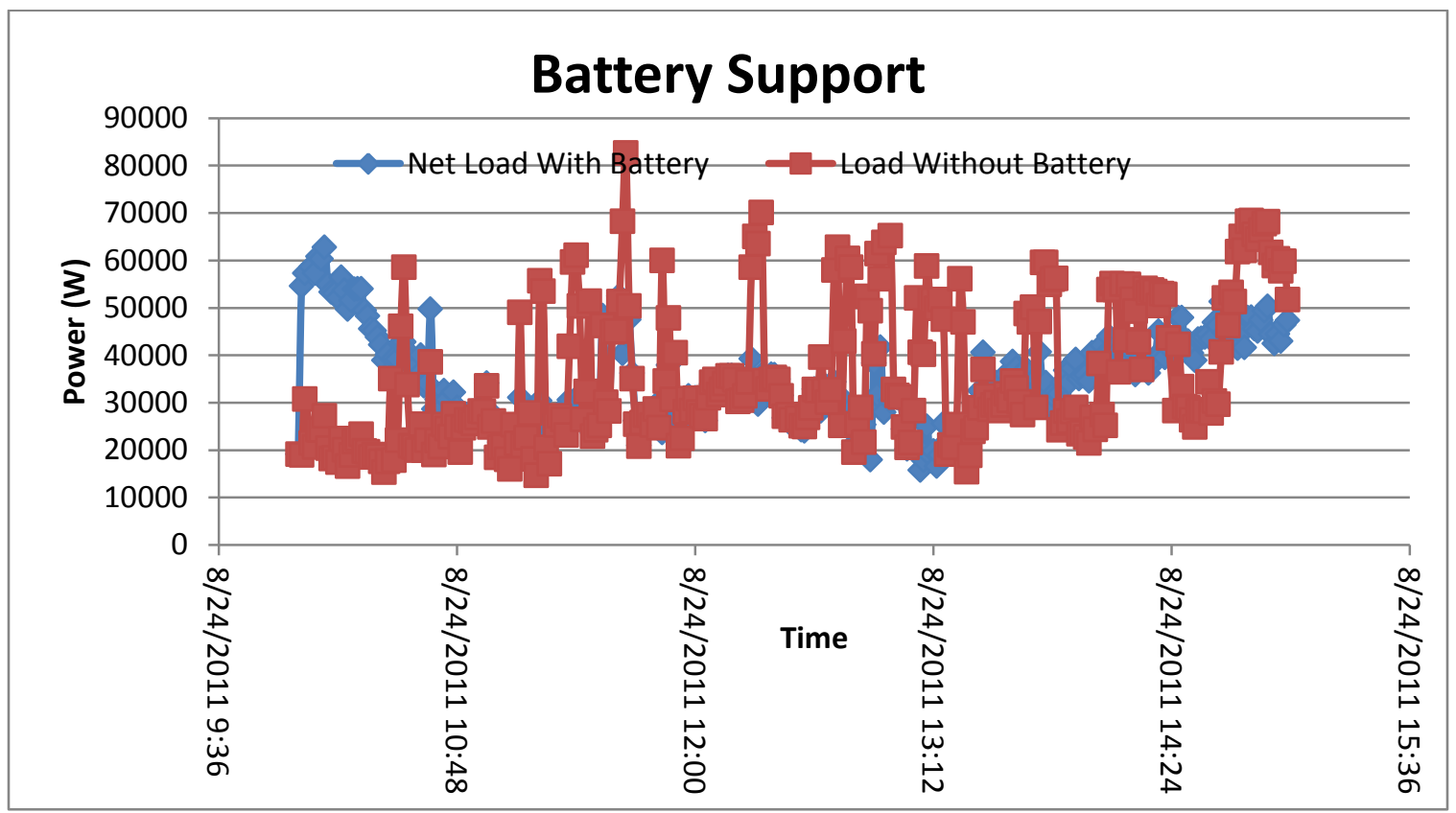

Figure 3-6: Load Profile after Battery Support 
In Figure 3-5 the plot of 'Load without Battery' is a plot of the building load after PV power has been subtracted. 'Net Load with Battery' is a plot of the building load after the PV power has been subtracted and the battery power has been added. The 'Net Load with Battery' plot has a smoother profile than that of the 'Load without Battery' plot. The addition of the battery helps to smooth out the load profile. 


\section{PSCAD MODELING}

\subsection{PSCAD Software}

The Greensmith DESS system parameters and test data from section three are used to recreate the system using Power Systems Computer Aided Design (PSCAD 4.4.1.0). PSCAD is a power systems simulator that allows for the design and verification of all types of power systems and power electronic controls. The PSCAD simulation used for this report makes use of two previously created models.

\subsection{PV Model}

The PV model used in this report was developed by Dr. Athula Rajapakse of the University of Manitoba, Winnipeg, MD, Canada and was provided by the PSCAD technical support team. This model makes use of two custom library components. The two custom components are the PV array and the Maximum Power Point Tracker (MPPT). Figure 4-1 shows the PSCAD model of the two custom library components [12]. The third component on the right is a thermal model for calculating the PV temperature given solar radiation, wind velocity, ambient temperature, tilt angle of array, surface emissivity, etc. Since the thermal time constants are much larger than electrical time constants, in most EMT (Electromagnetic Transient) simulations use of constant cell temperature should be sufficient [12]. Therefore, the thermal model is not used in this report. 

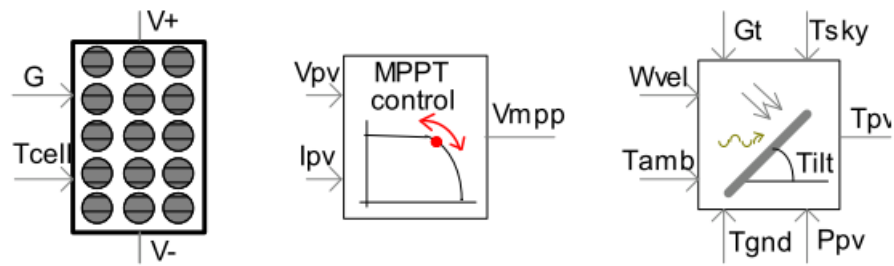

Figure 4-1: PV Array (left), MPPT Controller (middle), Thermal Model (right)

A solar cell can be modeled using an electrical equivalent circuit that contains a current source anti-parallel with a diode, a shunt resistance, and a series resistance [13]. An example of solar cell's electrical equivalent circuit model is shown in figure 4-2 [13].

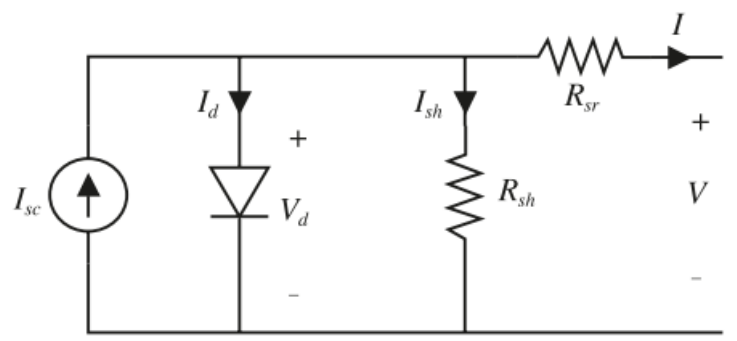

Figure 4-2: PV Cell Equivalent Circuit

The DC current that is generated when the cell is exposed to light varies linearly with solar irradiance. Solar cells are characterized by their nonlinear I-V curve. Figure 4-3 shows a typical PV cell's I-V characteristic [12].

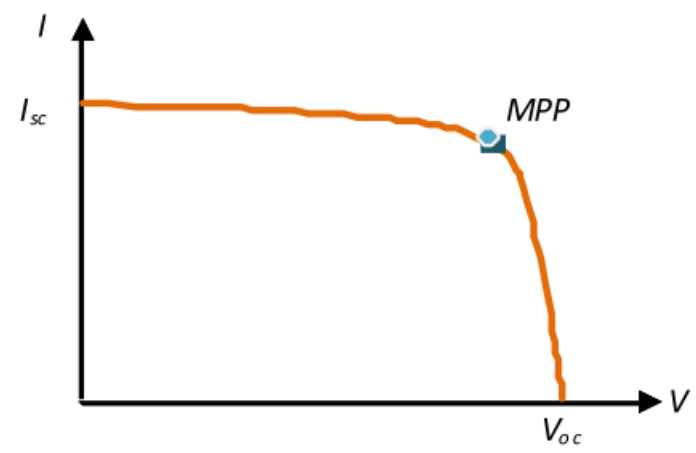

Figure 4-3: Typical I-V Characteristics of a PV Cell 
The basic equation that characterizes the solar cell I-V relationship can be derived considering the equivalent circuit shown in Figure 4-2. Kirchoff's current law of the circuit provides the following equation [12]:

$$
I=I_{s c}-I_{d}-I_{s h}
$$

After substitution of the equivalent diode current expression for $I_{d}$ and the shunt branch current $I_{\mathrm{sh}}$, equation (4-1) becomes the following equation [12]:

$$
I=I_{s c}-I_{o}\left[\exp \left(\frac{V+I R s r}{n k T_{c} / q}\right)-1\right]-\left(\frac{V+I R_{s r}}{R_{s h}}\right) .
$$

$I_{s c}$ is the photo current and it is a function of the solar radiation on the plane of the solar cell $\mathrm{G}$ and the cell temperature $\mathrm{T}_{\mathrm{c}}$. The photo current equation is as follows [12]:

$$
I_{s c}=I_{s c R} \frac{G}{G_{R}}\left[1+\alpha_{T}\left(T_{c}-T_{c R}\right)\right]
$$

$I_{s c R}$ is the short circuit current at the reference solar radiation $G_{R}$ and the reference cell temperature $T_{c R}$. The parameter $\alpha_{T}$ is the temperature coefficient of photo current. The current $I_{0}$ in equation (4-2) is called the dark current. It is a function of cell temperature only, and is given by [12]:

$$
I_{o}=I_{o R}\left(\frac{T_{c}^{3}}{T_{c R}^{3}}\right) \exp \left[\left(\frac{1}{T_{c R}}-\frac{1}{T_{c}}\right) \frac{q e_{g}}{n k}\right]
$$

$\mathrm{I}_{\mathrm{OR}}$ is the dark current at the reference temperature. The other parameters appearing in (4-2), (4-3), and (4-4) are the electron charge q, the Boltzmann constant k, the band-gap energy of the solar cell material $e_{g}$, and the diode ideality factor $n$. The constants of the equations above can be determined by examining the manufacturer's specifications of the PV modules and its corresponding I-V curves. A PV array is 
composed of series and parallel connected modules and the single cell circuit can be scaled up to represent any series/parallel combination [12]. Figure 4-4 shows the default PV cell parameters that were used in this simulation.

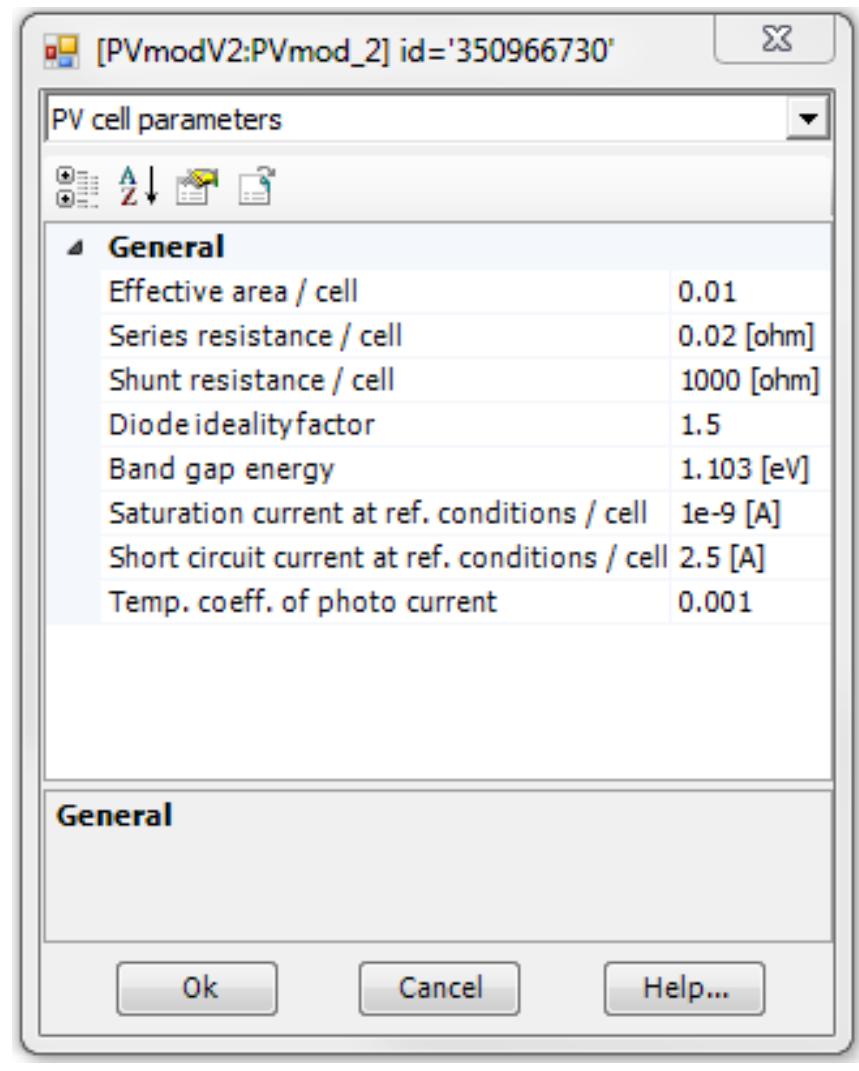

Figure 4-4: PV Cell Parameters

The Greensmith model uses simulated solar data based on a $50 \mathrm{~kW}$ array model. Therefore, the PSCAD PV array parameters are set up to emulate a $50 \mathrm{~kW}$ model. Figure 4-5 shows the PV array parameters used to model a $50 \mathrm{~kW}$ array. 


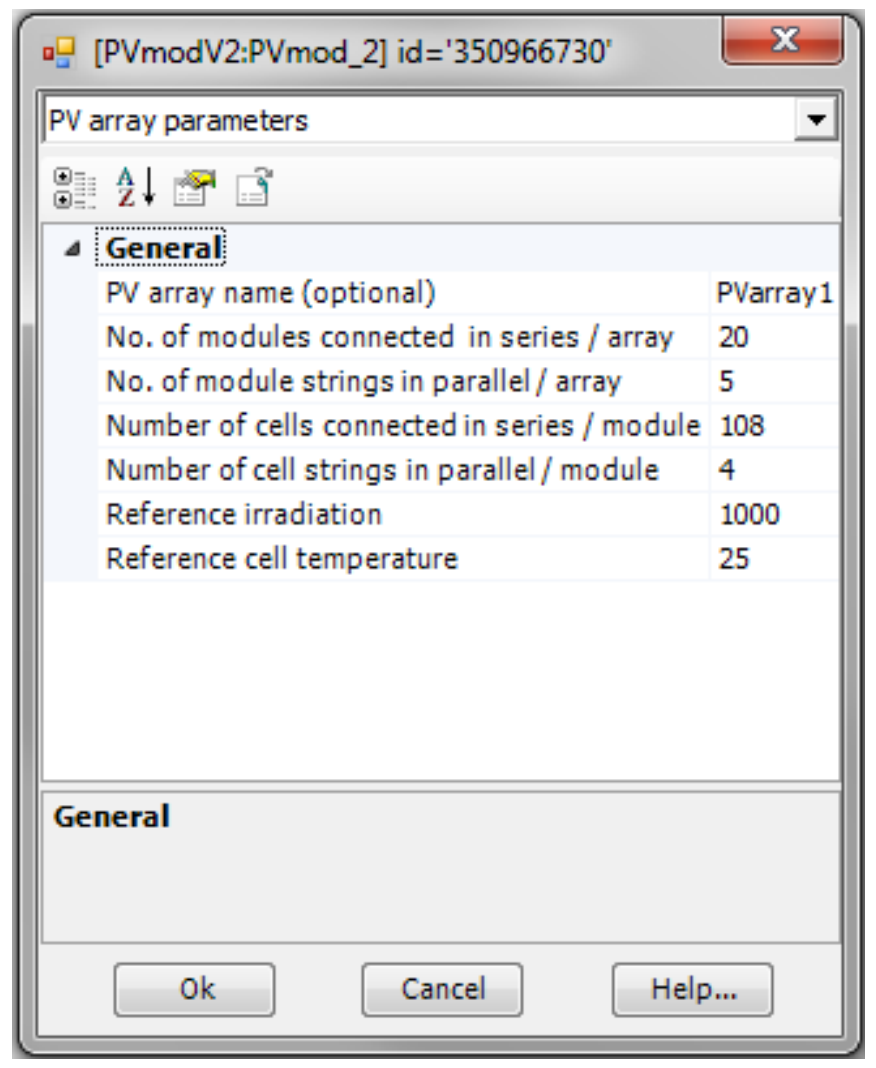

Figure 4-5: 50 kW PV Array Parameters

\subsection{The MPPT Model}

Figure 4-3 shows that the optimum operating point of solar cells occurs at the knee of the I-V curve. In order to extract the maximum amount of power from a PV array, it is desirable to operate at the optimum operating point at all times. A Maximum Power Point Tracker (MPPT) is a DC-DC converter that is placed between a PV array and its load to ensure that the PV array operates at its optimum point despite varying temperature, insolation, and load. The DC-DC converter is also necessary to regulate and step-down the high voltage of the PV array. Figure 4-1 shows the MPPT custom library component that was developed in PSCAD. There are a number of different MPPT algorithms. A popular implementation is the Perturb and Observe (P \& O) algorithm, but it has limitations. The algorithm used in this model is based on the Incremental 
Conductance (INC) method. The advantage that this algorithm has over the $\mathrm{P} \& \mathrm{O}$ method is that it can stop and determine when the maximum power point is reached without having to oscillate around this value. It can also perform MPPT under rapidly varying irradiation conditions with higher accuracy than the P \& O method [14]. However, a disadvantage of the INC method is that it can produce oscillations and can perform erratically under rapidly changing atmospheric conditions. Also, the computation time is longer than that of the $\mathrm{P} \& \mathrm{O}$ method due to the slowing down of the sampling frequency resulting from the higher complexity of the algorithm [15]. The Incremental Conductance algorithm is shown in Figure 4-6 and it was implemented in PSCAD [12].

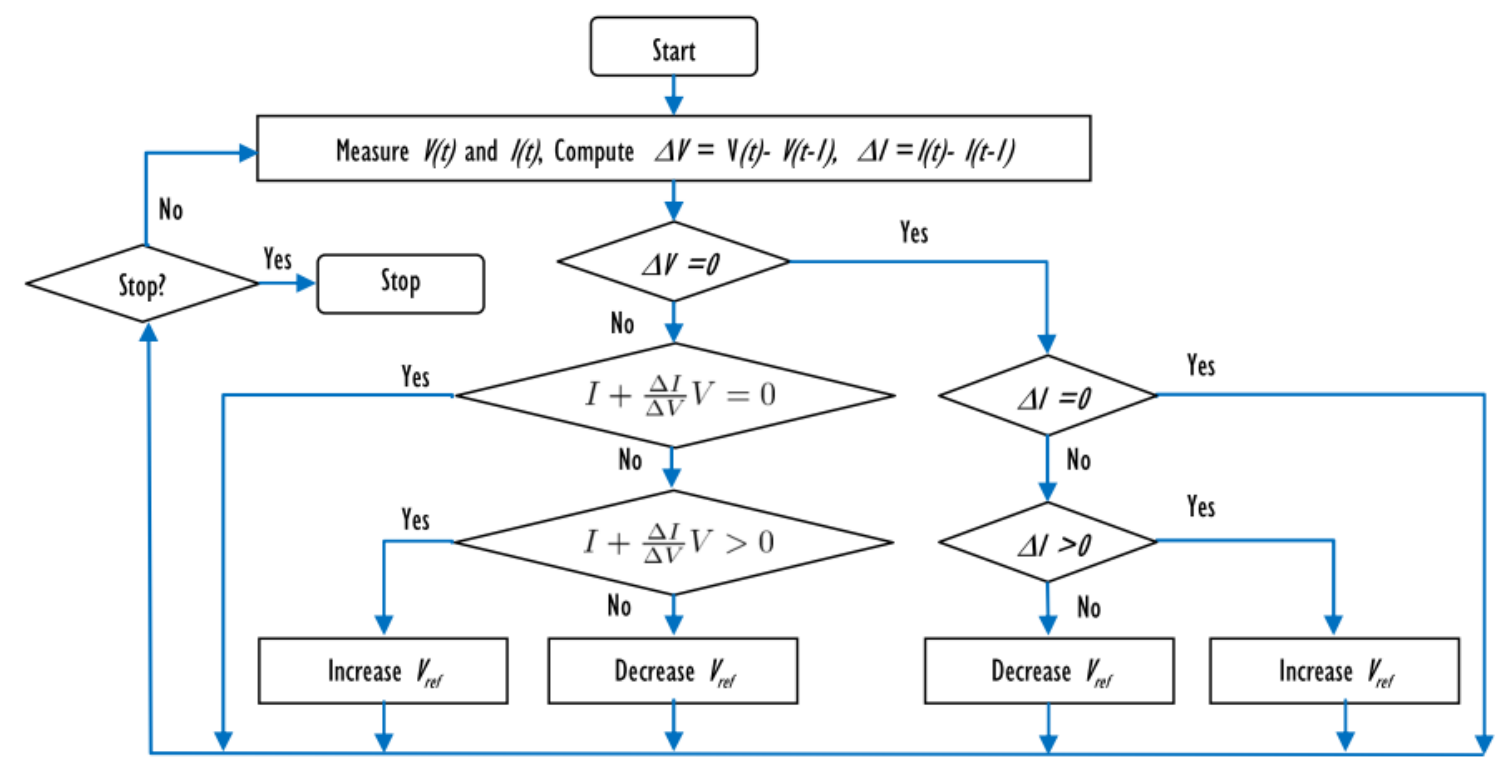

Figure 4-6: Incremental Conductance Based MPPT Algorithm

The controller used for the maximum power point tracking DC-DC converter is shown in Figure 4-7 [12]. 


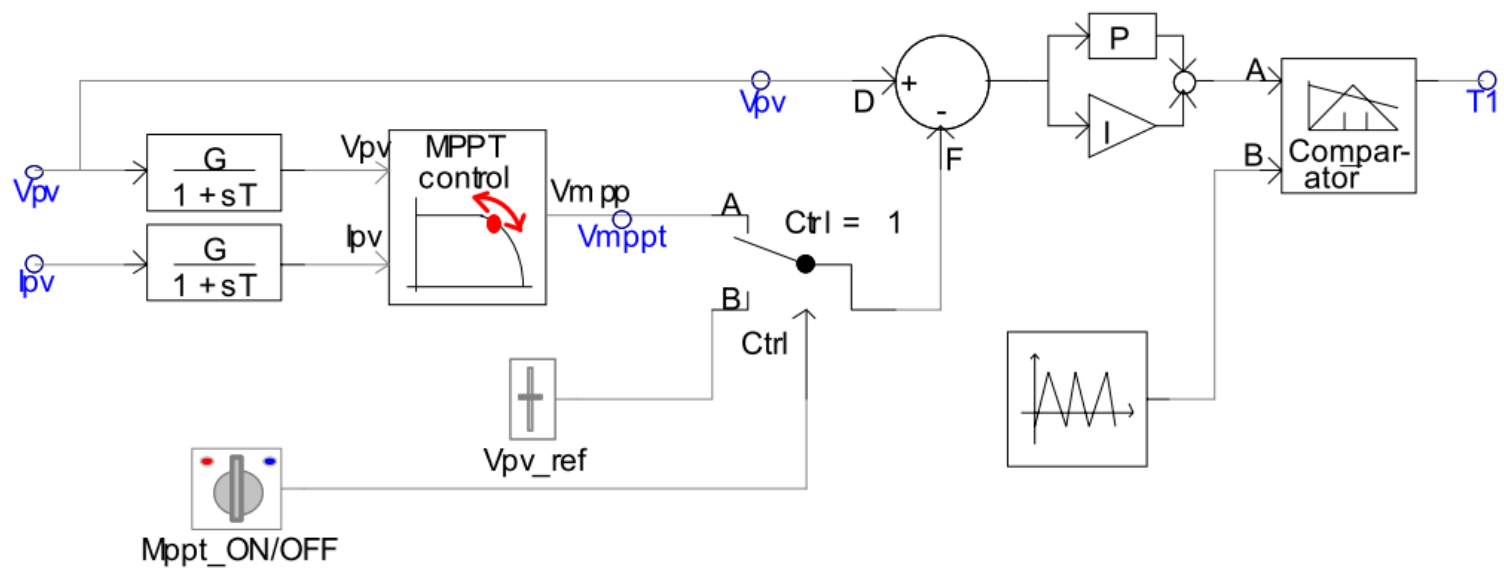

Figure 4-7: DC-DC Converter Controller with MPPT

Figure 4-8 shows the MPPT's parameters. The parameters are the PV array's $\mathrm{I}_{\mathrm{SC}}$, $\mathrm{V}_{\mathrm{OC}}$, sampling interval, and the initial value of the $\mathrm{V}_{\mathrm{mpp}}$.

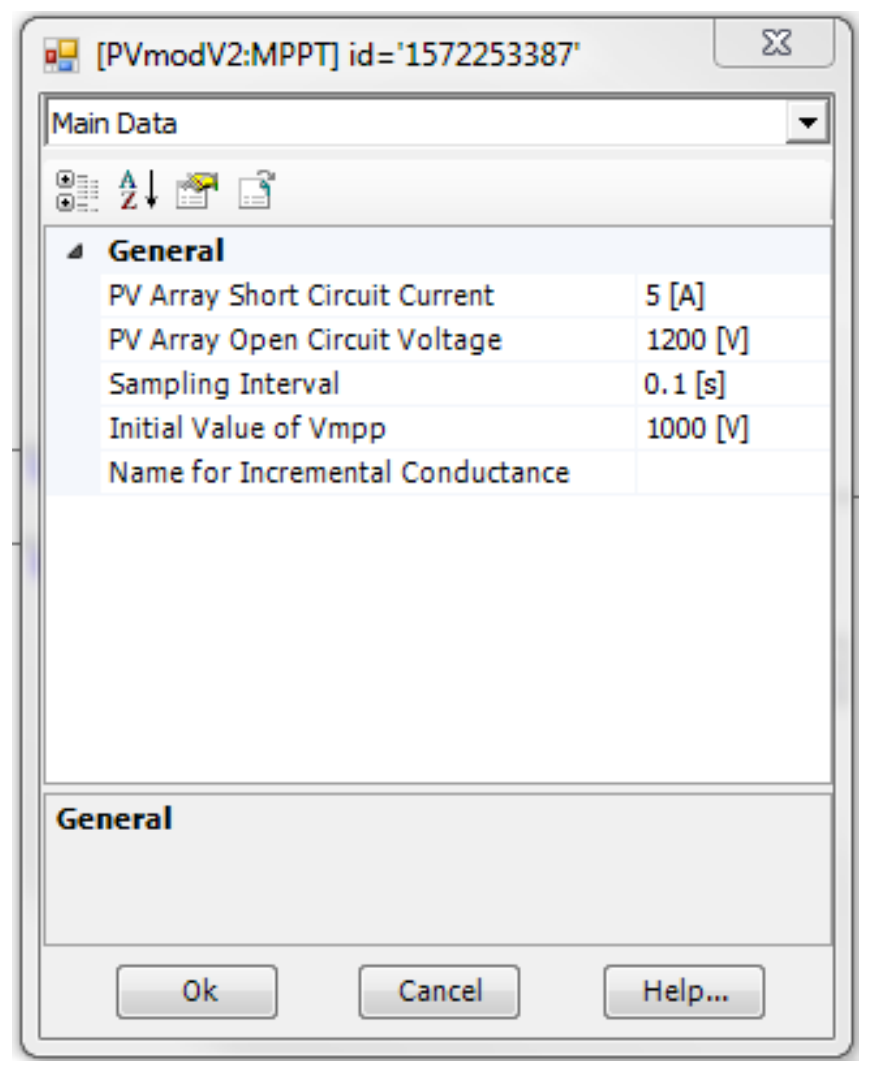

Figure 4-8: MPPT Parameters 
Figure 4-9 shows how the MPPT controller is able to track the optimum operating point for varying solar radiation and temperature conditions [12]. The thick green line indicates the variation of the PV array operating point during the variations of the solar radiation and cell temperature. The MPPT controller accurately tracks the knee point $[12]$.

- I- V curve

- Operating Point

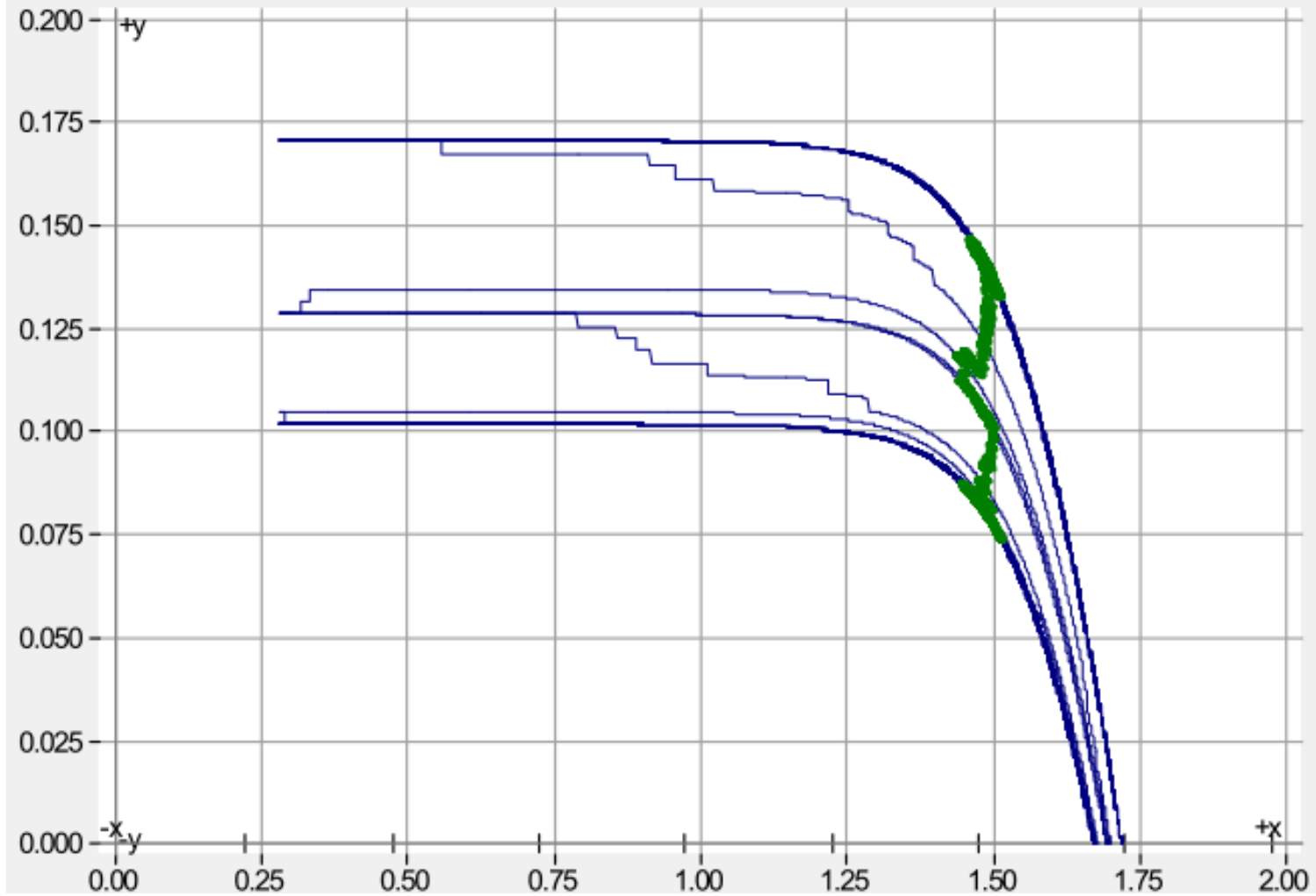

Figure 4-9: MPP Tracking Under Variable Solar Radiation and Temperature Conditions

\subsection{Grid Connected PV System}

The grid connected PV system is shown in Figure 4-10 [12]. The PV array is connected to the input of a DC-DC converter. The DC-DC converter is a buck converter that is controlled using the MPPT system. The output of the converter is the input to the three-phase inverter. The three-phase inverter is controlled using a simple $\mathrm{P}$ and $\mathrm{Q}$ 
controller that is discussed further in section 5.2. Figures 4-11 and 4-12 show the inverter's $\mathrm{P}$ and $\mathrm{Q}$ regulation controller and firing pulse generator respectively.

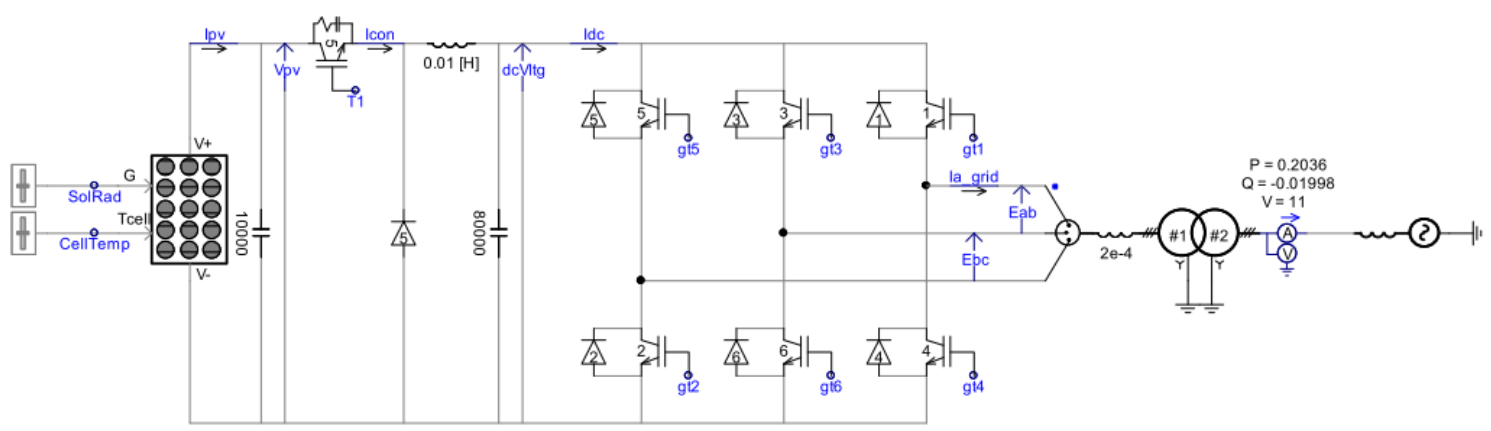

Figure 4-10: Grid Connected PV System
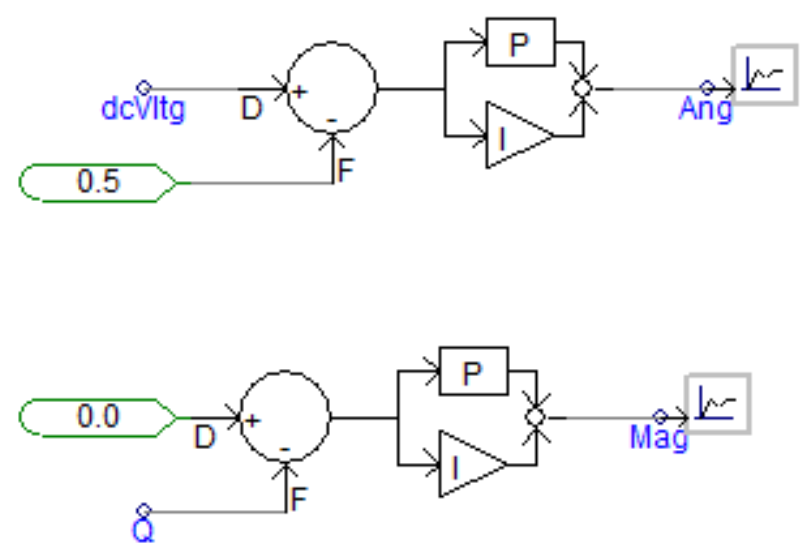

Figure 4-11: Simple P and Q Regulation Inverter Controller 


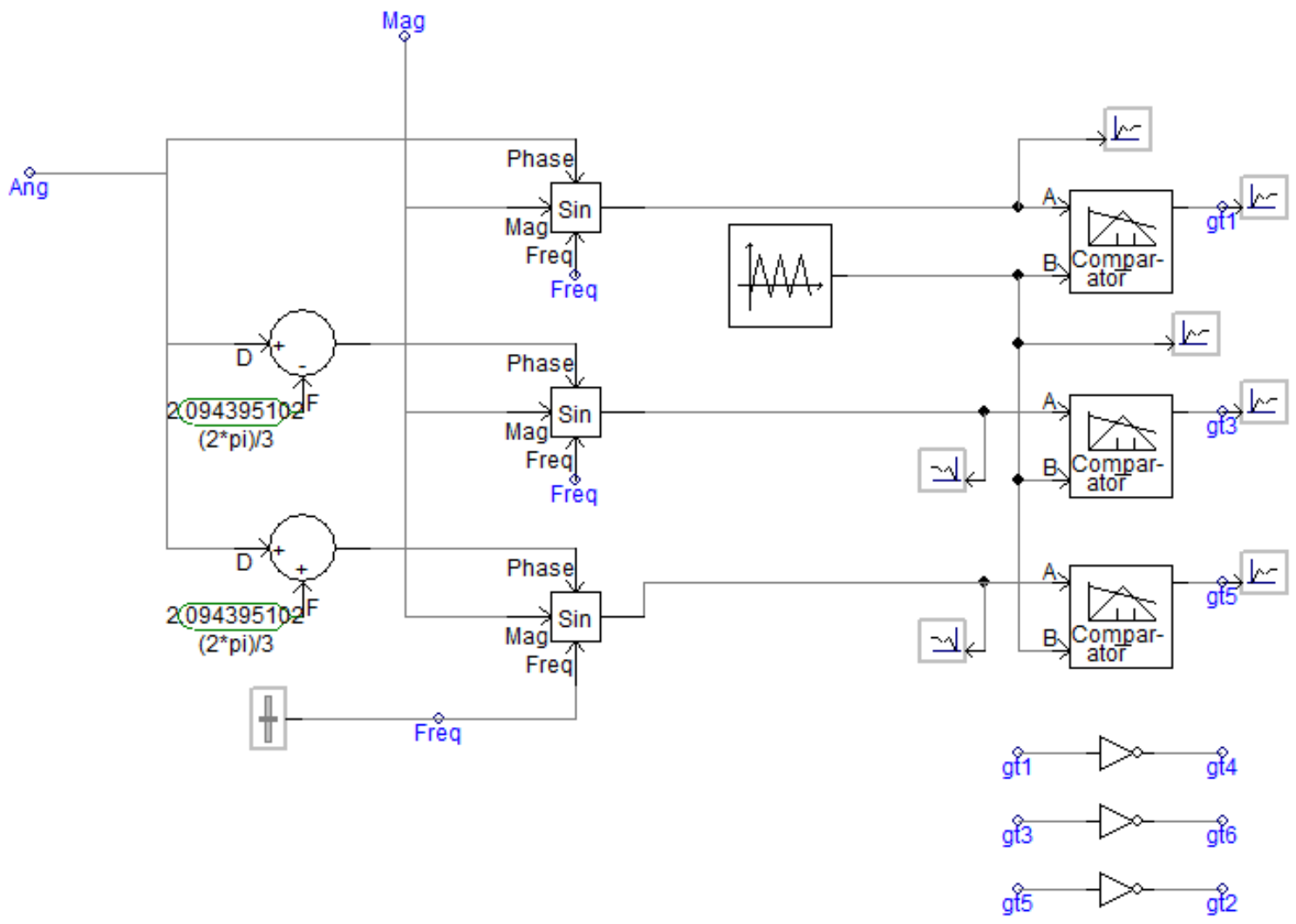

Figure 4-12: Firing Pulse Generation for Inverter

The grid system is represented as an equivalent source behind the system impedance [12]. The inverter is connected to the $11 \mathrm{kV}$ source through a step-up transformer [12]. Except for the transformer winding inductance and the smoothing inductor, no additional harmonic filter is provided [12]. Modifications were made to the system shown in Figure 4-10 in order to emulate the Greensmith system. The final system is discussed in section 4.7 .

\subsection{Battery Model}

An electrochemical battery model was used to model the Greensmith Distributed Energy Storage System in PSCAD. The battery model was provided by PSCAD's Technical Support Team and will be incorporated into PSCAD's Master Library in the future. There are many different types of batteries as well as many different factors that 
affect their performance. There are four main cell chemistries in use for rechargeable batteries: lead-acid, nickel-cadmium (Ni-Cd), nickel metal hydride (Ni-MH), and lithiumion (Li-ion). The discharge characteristic of common rechargeable batteries is shown below in Figure 4-13 [16].

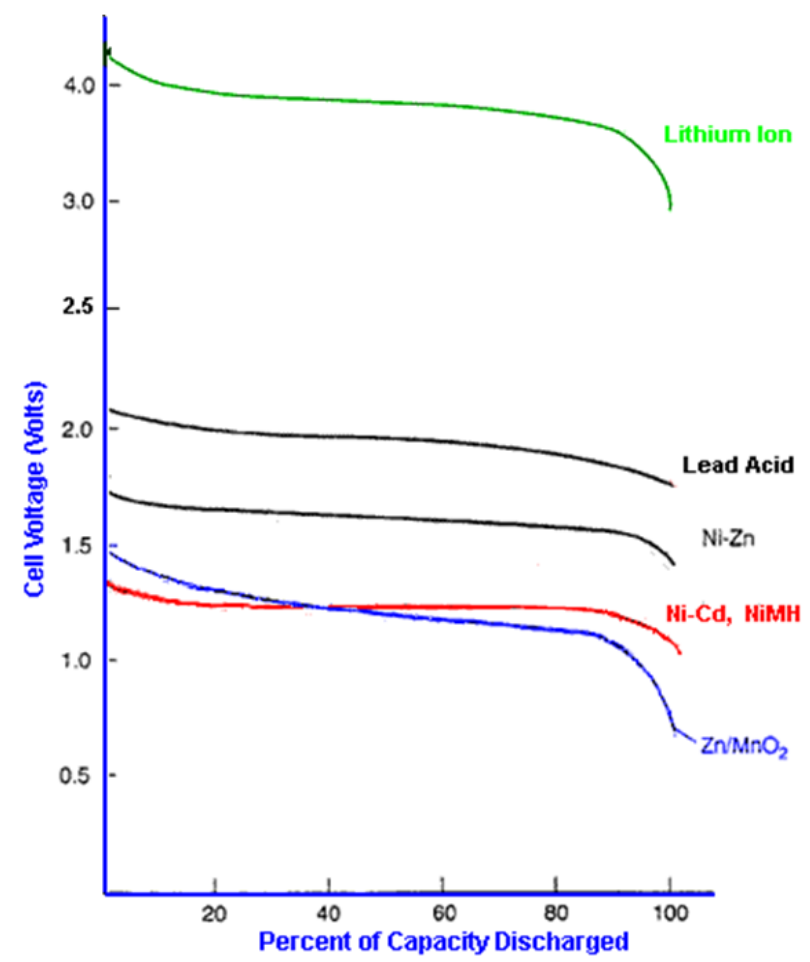

Figure 4-13: Discharge Profiles of Various Cell Chemistries

The charge characteristic has a similar profile to that of the discharge characteristic. Hence for this system model, the charge and discharge characteristic can be described by the same equation if the battery hysteresis effect is neglected. Figure 414 shows the charge and discharge characteristic of a typical battery cell [16]. 


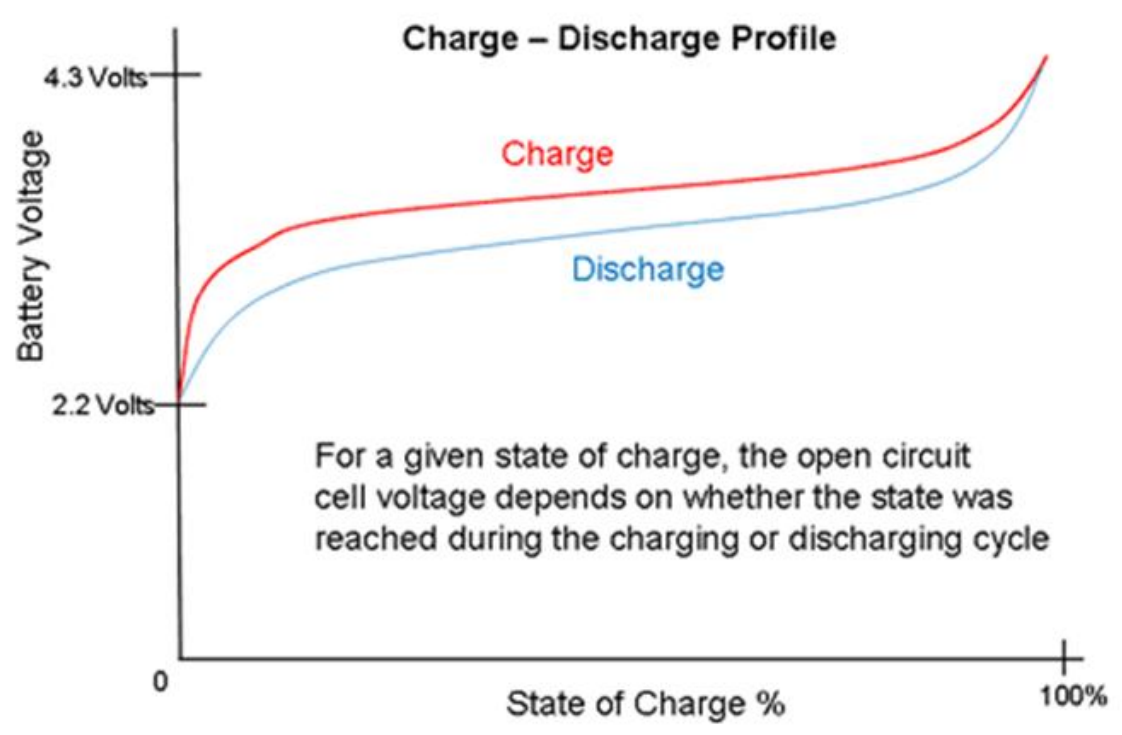

Figure 4-14: Charge - Discharge Profile

Some important terminologies of batteries include [16]:

1. Rated capacity: The ampere-hours a fully charged battery can deliver at a specified rate $(\mathrm{C} / 2$ or $\mathrm{C} / 20$ rates are typically used here $)$

2. Nominal voltage: The voltage of the battery under normal operating conditions

3. State of charge (SOC): An expression of the present battery capacity as a percentage of maximum capacity

4. Charging rate ( $\mathrm{C}$ rate): The amount of current that a battery can deliver for 1 hour from fully charged to the end of life. For a 100 Ah battery, 1C means the discharging current is $100 \mathrm{~A}, 0.2 \mathrm{C}$ means $20 \mathrm{~A}, 5 \mathrm{C}$ means $500 \mathrm{~A}$

5. Internal resistance: The Thevenin resistance within the battery

PSCAD based their battery model off a model described in [17]. The battery component that was developed for PSCAD is based on Shepherd's equation, which is used to represent a battery's electromechanical performance [16]. The battery is modeled 
by a controlled voltage source in series with a constant resistance, as shown in Figure 4$15[16]$.

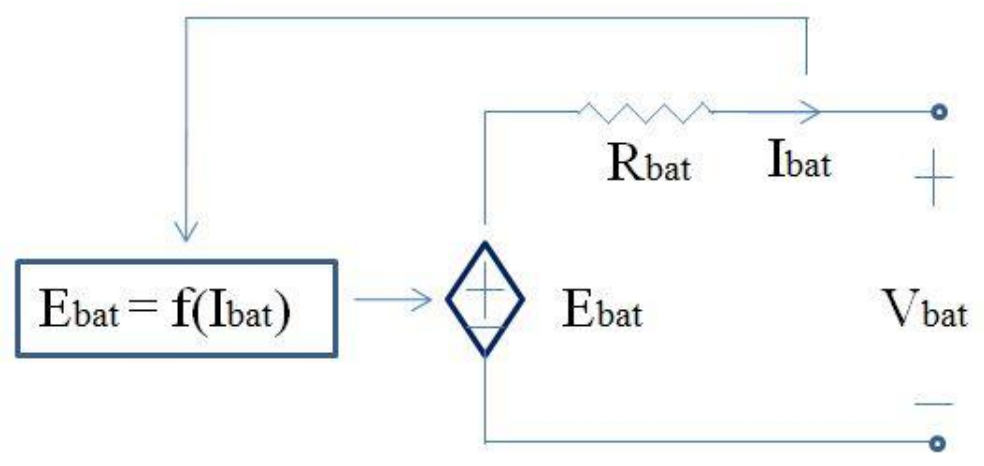

Figure 4-15: Equivalent Circuit of Battery

The equivalent circuit above is represented by the following equations which are based on Shepherd's equation [16]:

$$
\begin{gathered}
E b a t=E 0-K \cdot \frac{1-S O C}{S O C} \cdot Q+A \cdot e^{-B \cdot(1-S O C) \cdot Q} \\
\text { Vbat }=E_{b a t}-R_{b a t} \cdot I_{b a t}
\end{gathered}
$$

Where:

$$
\begin{aligned}
& \mathrm{E}_{\text {bat }}: \text { internal voltage }(\mathrm{V}) \\
& \mathrm{E}_{\mathrm{o}}: \text { battery voltage constant }(\mathrm{V})
\end{aligned}
$$

SOC: state of charge $(\%)$

Q: battery capacity (Ah)

A: exponential zone amplitude (V)

B: exponential zone time constant inverse (1/Ah)

$\mathrm{V}_{\text {bat }}$ : terminal voltage $(\mathrm{V})$

$\mathrm{I}_{\text {bat }}$ : battery current $(\mathrm{A})$ 
$\mathrm{R}_{\text {bat }}$ internal resistance $(\Omega)$

$\mathrm{K}$ : polarization constant (V/Ah) or polarization resistance $(\Omega)[18]$

The model is based on a few simplifying assumptions [17]:

1. The internal resistance is assumed constant during the charge and discharge cycles and doesn't vary with the amplitude of the current

2. The model's parameters are deduced from the discharge characteristics and assumed to be the same for charging

3. The capacity of the battery doesn't change with the amplitude of the current (i.e. no Peukert Effect).

4. The temperature doesn't affect the model's behavior

5. The self-discharge of the battery is not represented

6. The battery has no memory effect

7. Charging and discharging history does not affect battery characteristics (i.e. no hysteresis)

The main feature of this battery model is that the parameters can be easily determined from a manufacturer's discharge curve. Figure 4-16 shows the typical discharge characteristic of a 1.2 V 6.5 Ah nickel-hydride (Ni-MH) cell [17]. It is used here as an example of how to set up the parameters of the battery model. 


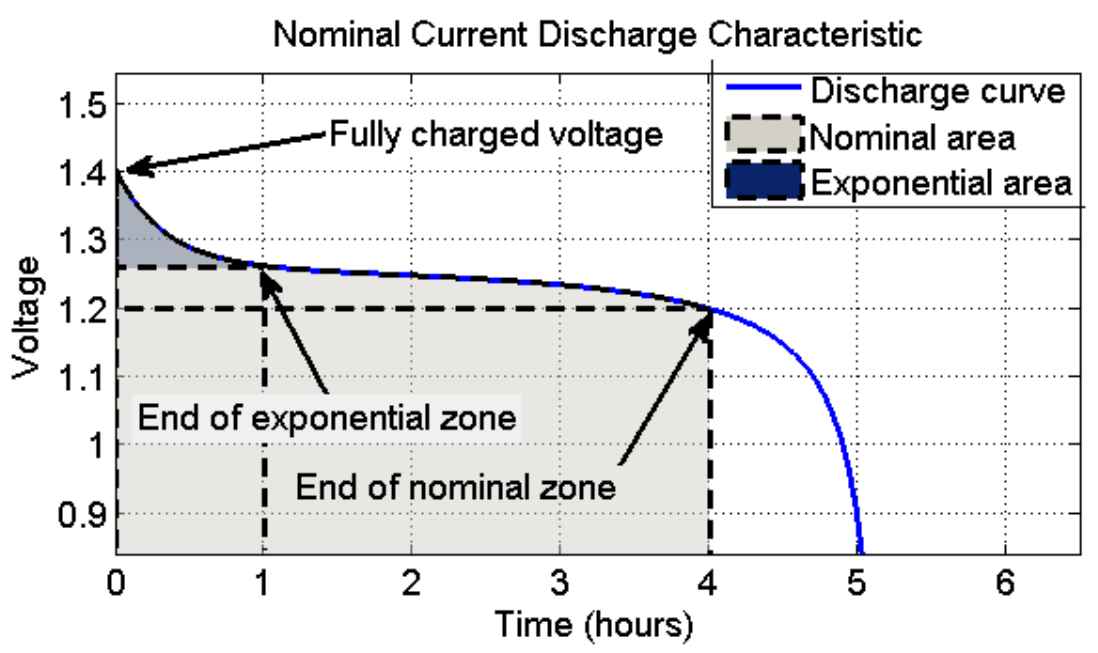

Figure 4-16: Typical Discharge Curve

The three points that define the shape of the curve are the fully charged voltage, end of exponential zone voltage, and the end of the nominal zone voltage [17]. The zone occurring after the nominal zone is not generally useful and is therefore not covered here. The internal voltage characteristic equation (4-5) is described by the sum of three mathematical functions [16]:

1. The exponential curve $A \cdot e^{-B \cdot(1-S O C) \cdot Q}$ represents the section from fully charged to the end of the exponential zone

2. The nominal zone line $-K \cdot \frac{1-S O C}{S O C} \cdot Q$ represents the middle section from the end of the exponential zone to the end of the nominal zone

3. The DC transition level of $\mathrm{E}_{0}$ is the value at the transition between the end of the exponential zone and the beginning of the fully charged zone.

The discharge curve of Figure 4-16 is applied to equation (4-5) to show how a discharge curve can be used to form an equation of the battery's internal voltage. The equations can be fit to the example data as follows [17]: 
A: Voltage drop during the exponential zone (V)

$$
A=E_{\text {full }}-E_{\text {exp }}=1.4-1.25=0.15(V)
$$

3/B: Charge at the end of exponential zone (Ah)

$$
B=\frac{3}{Q_{\exp }}=\frac{3}{1.3 A \cdot 1 h}=2.308(A h)^{-1}
$$

K: The polarization constant (V/Ah)

$$
\begin{gathered}
K=\frac{\left(E_{\text {full }}-E_{\text {nom }}+A \cdot\left(e^{-B \cdot Q_{\text {nom }}}-1\right)\right) \cdot\left(Q-Q_{\text {nom }}\right)}{Q_{\text {exp }}} \\
K=\frac{\left(1.4-1.2+0.15 \cdot\left(e^{-2.31 \cdot 5.2}-1\right)\right) \cdot(6.5-5.2)}{5.2}=0.0125(\mathrm{~V} / \mathrm{Ah})
\end{gathered}
$$

$\mathbf{E}_{\mathbf{0}}$ : Voltage constant (V)

For the fully charged voltage, the extracted charge is zero [18].

$$
\begin{gathered}
E_{0}=E_{\text {full }}+R_{\text {bat }} \cdot I_{\text {bat }}-A \\
E_{0}=1.4+0.0046 \cdot 1.3-0.15=1.256(V)
\end{gathered}
$$

After substitution of the $1.2 \mathrm{~V} 6.5 \mathrm{Ah} \mathrm{Ni}-\mathrm{MH}$ cell's mathematical constants, equation (4-5) becomes the following:

$$
\begin{gathered}
E_{\text {bat }}=E_{O}-K * \frac{1-S O C}{S O C} * Q+A e^{-B(1-S O C) Q} \\
E_{\text {bat }}=1.256-0.0125 * \frac{1-S O C}{S O C} * 6.5+0.15 e^{-2.308(1-S O C) 6.5}
\end{gathered}
$$


This is a general approach to obtaining the model parameters that can be applied to other battery types. The parameters of other common battery cells are presented in Table 4-1 [17].

Table 4-1: Battery Parameters

\begin{tabular}{||c||c|c|c|c||}
\hline \hline Type & $\begin{array}{c}\text { Lead- } \\
\text { Acid } \\
\text { Parameters }\end{array}$ & $\begin{array}{c}\text { Nickel- } \\
\text { Cadmium } \\
12 \mathrm{~V} \mathrm{1.2Ah}\end{array}$ & $\begin{array}{c}\text { Lithium- } \\
\text {-Ion } \\
\text {-I.2V 1.3Ah }\end{array}$ & $\begin{array}{c}\text { Nickel- } \\
\text { Metal-Hydrid } \\
1.2 \mathrm{~V} 1 \mathrm{Ah}\end{array}$ \\
\hline \hline$E_{0}(V)$ & 12.6463 & 1.2505 & 3.7348 & 1.2848 \\
\hline $\mathrm{R}(\Omega)$ & 0.25 & 0.023 & 0.09 & 0.0046 \\
\hline $\mathrm{K}(\mathrm{V})$ & 0.33 & 0.00852 & 0.00876 & 0.01875 \\
\hline $\mathrm{A}(\mathrm{V})$ & 0.66 & 0.144 & 0.468 & 0.144 \\
\hline $\mathrm{B}(A h)^{-1}$ & 2884.61 & 5.7692 & 3.5294 & 2.3077 \\
\hline \hline
\end{tabular}

Equation (4-5) is implemented in PSCAD's battery model. The battery component in PSCAD is shown below in Figure 4-17 [16].

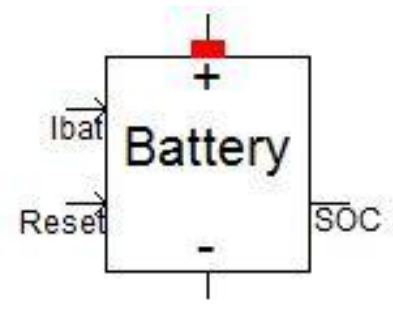

Figure 4-17: PSCAD Battery Custom Component

The input and output signals of the battery model are the following:

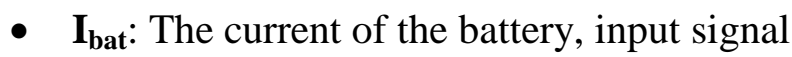

- Reset: The control signal used to control charge or discharge of the battery, input signal

- SOC: State of charge, output signal

The dialog box for the battery model is shown below in Figure 4-18 [16]. 


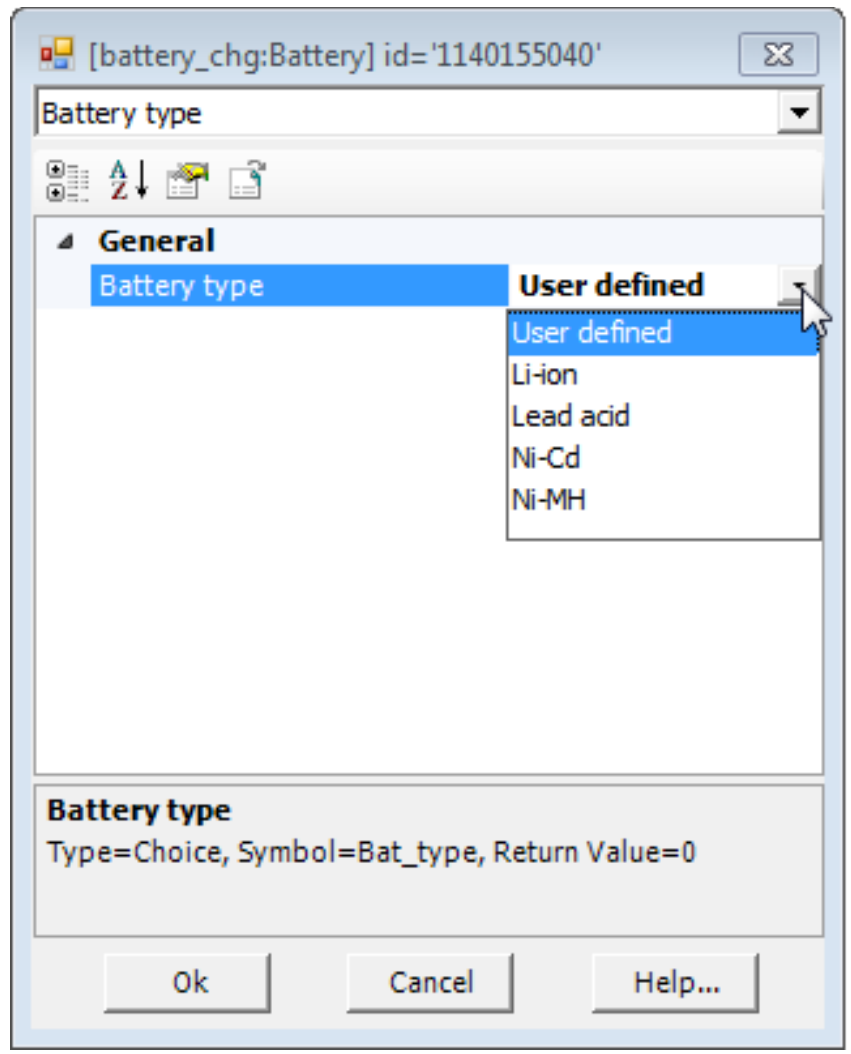

Figure 4-18: Battery Model's Available Configurations

There are five options for Battery Type. They are the following [16]:

- User defined model: the characteristics of voltage vs. SOC and the internal resistance vs. SOC are defined as the tabulated inputs directly. This allows for a variable internal resistance.

- The other four options are electrochemical models based on the modified Shepherd model. The internal resistances are constant.

- Lead Acid

○ Nickel-Cadmium (Ni-Cd)

- Nickel Metal Hydride (Ni-MH)

○ Lithium-Ion (Li-Ion).

The parameters of the four electromechanical models are [16]: 
- Nominal Voltage (V): The nominal voltage represents the end of the linear zone of the discharge characteristics

- Rated Capacity (Ah): The rated capacity is the rated capacity of the battery

- Initial Capacity (Ah): It is used as an initial condition for the simulation and does not affect the discharge curve

- Nominal capacity (Ah): It is extracted from the battery until the voltage drops under the nominal voltage

- Voltage at exponential point $(\mathrm{V})$ : The voltage corresponds to the end of the exponential zone

- Maximum Voltage (V): The fully charged voltage

- Internal Resistance $(\boldsymbol{\Omega})$ : It is the constant for all electromechanical models

Figure 4-19 shows the PSCAD parameters of a 3.6V 1 Ah Li-Ion battery [16].

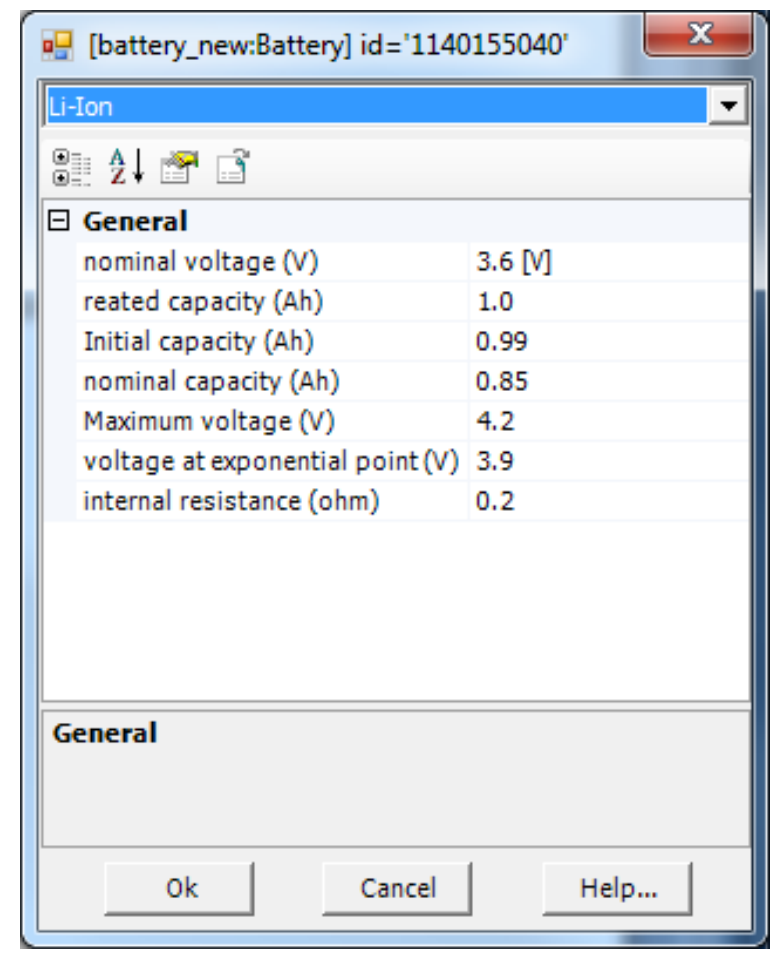

Figure 4-19: 3.6V 1Ah Li-Ion Battery Specifications 
In order to validate the battery model, a test case was developed in PSCAD. The following test case was implemented in [16] and is used to demonstrate the charge and discharge characteristics of the battery model. Figure 4-20 shows the circuit that was used to test the charging and discharging characteristics of the battery model [16]. A $4.2 \mathrm{~V}$ voltage source and a $3.6 \mathrm{~V}, 1 \mathrm{Ah}$ Li-Ion battery are connected in parallel with different loads $(1.8,3.6,7.2$, and $18 \Omega)$.

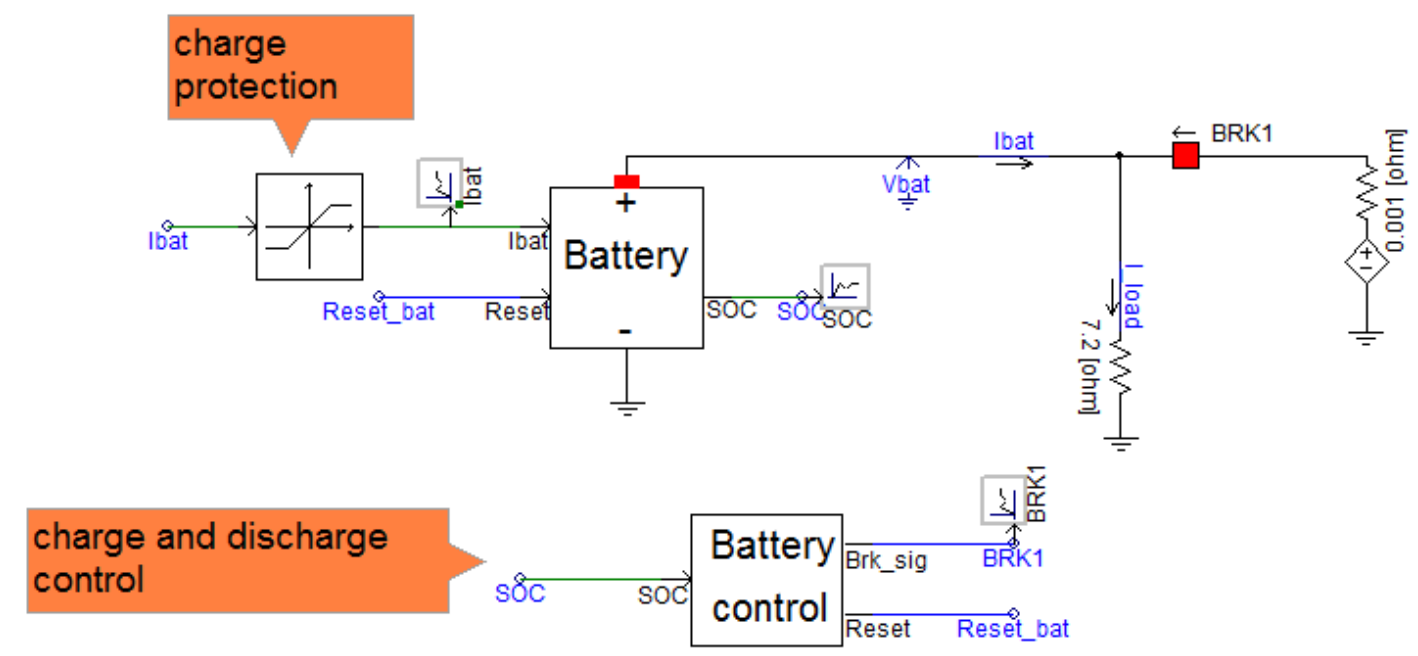

Figure 4-20: Charging and Discharging Circuit

Figure 4-21 shows the Li-Ion battery's discharge curves with different $\mathrm{C}$ rates [16]. 


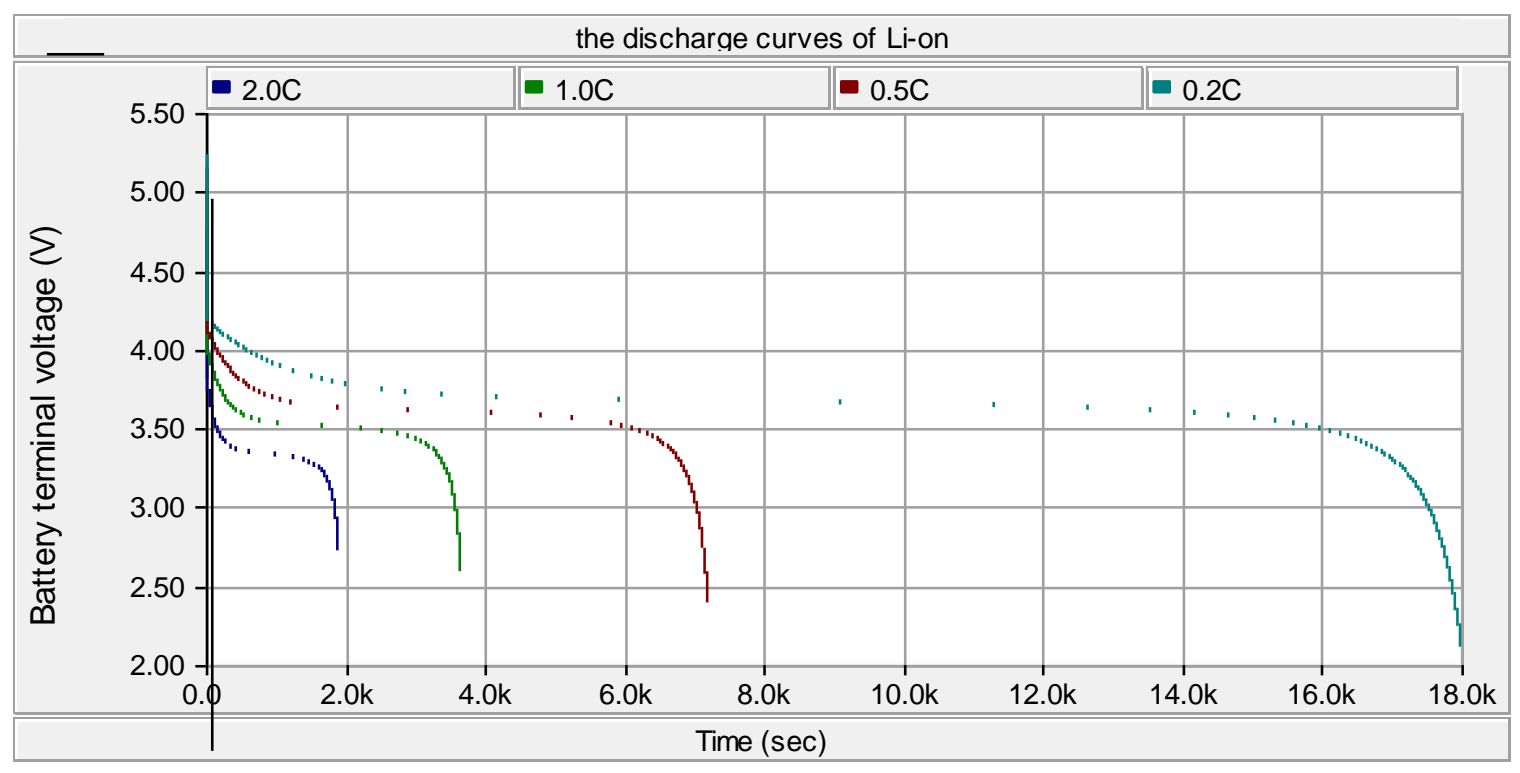

Figure 4-21: Battery Discharge Curves for Different C Rates

Another test was conducted on this case to monitor the battery terminal voltage, SOC, battery current, and load current through a charge and discharge cycle. The battery controller is set up so that when the battery capacity is lower than $30 \%(\mathrm{SOC}<0.3)$ of the rated capacity, the voltage source begins to charge the battery and supplies the load. The voltage source stops charging the battery after the capacity reaches $80 \%$ (SOC $=$ 0.8 ), and the battery takes over the load until its SOC $<0.3$. After that, the chargedischarge cycle repeats itself. The simulation results are shown below in Figure 4-22 [16]. 


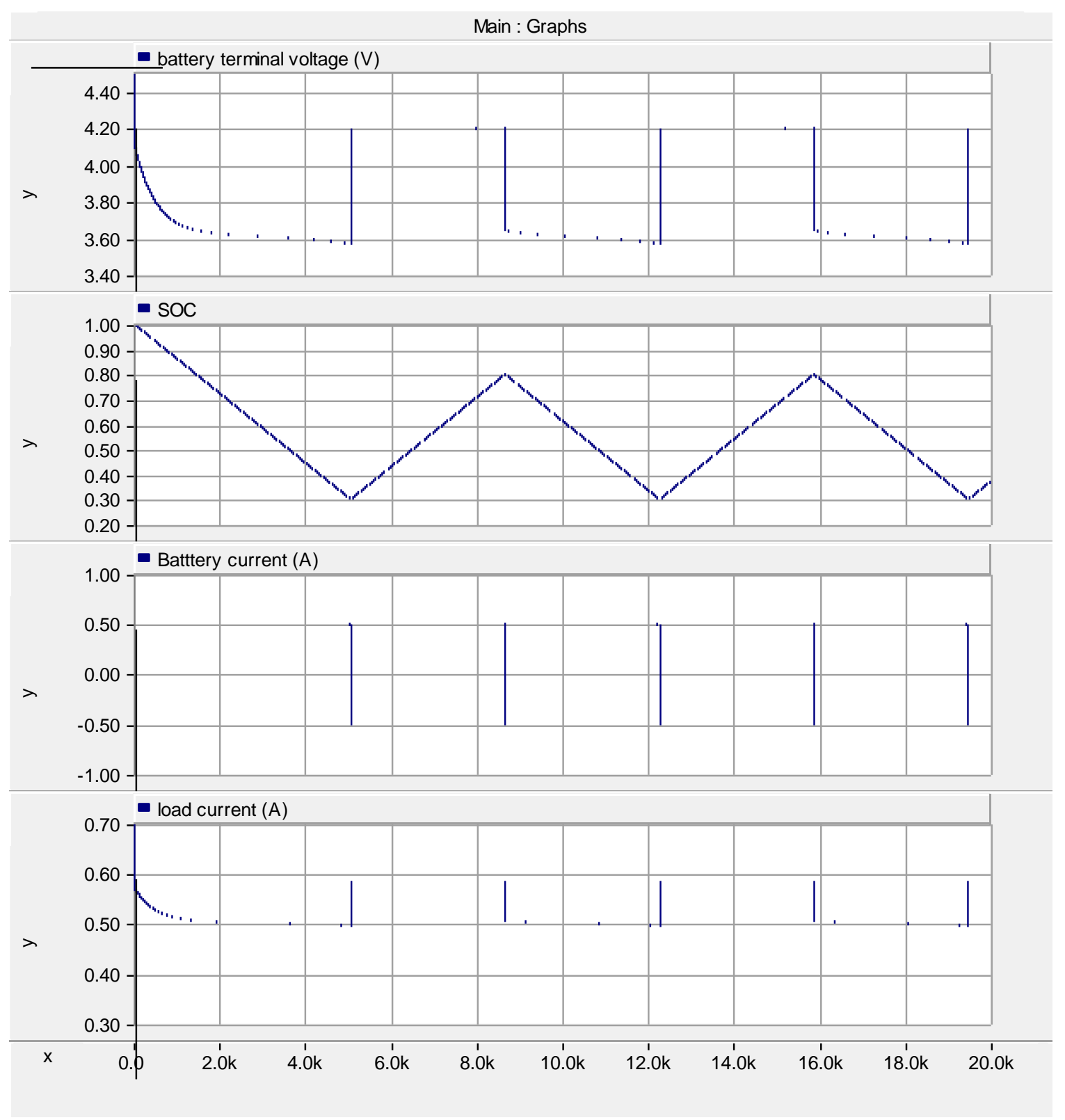

Figure 4-22: Charging and Discharging Simulation

The battery starts off by supplying the load with $0.5 \mathrm{C}(0.5 \mathrm{~A}$ when load resistance $=7.2 \Omega$ ). At $5000-8600 \mathrm{sec}$, it is charged with $0.5 \mathrm{C}$ by the voltage source, and then discharged at $8600-12200 \mathrm{sec}$ [16]. These two tests illustrate the charge and discharge characteristics of the battery model. 
The PSCAD battery model is used to model the Greensmith battery pack. In order to accurately model the Greensmith battery, the parameters of a single IB-B-FHE160 battery cell were scaled up in order to be equivalent to the Greensmith battery. The parameters were determined as follows:

- Nominal Voltage (V): $(3.2 \mathrm{~V})(160$ cells in series $)=512 \mathrm{~V}$

- Rated Capacity (Ah): 160Ah

- Initial Capacity (Ah): User-Defined: 0 - 160Ah

- Nominal capacity (Ah): 120Ah

- Voltage at exponential point $(\mathrm{V}):(3.3 \mathrm{~V})(160$ cells in series $)=528 \mathrm{~V}$

- Maximum Voltage (V): $(3.6 \mathrm{~V})(160$ cells in series $)=576 \mathrm{~V}$

- Internal Resistance $(\boldsymbol{\Omega}):(0.75 \mathrm{~m} \Omega)(160$ cells in series $)=0.12 \Omega$

These parameters are used to define the Greensmith battery. The internal capacity can be set as any value between 0 - 160Ah and represents the battery's SOC. Figure 4-23 shows these parameters entered into the PSCAD battery model specifications. These parameters were used to model the DESS in PSCAD. 


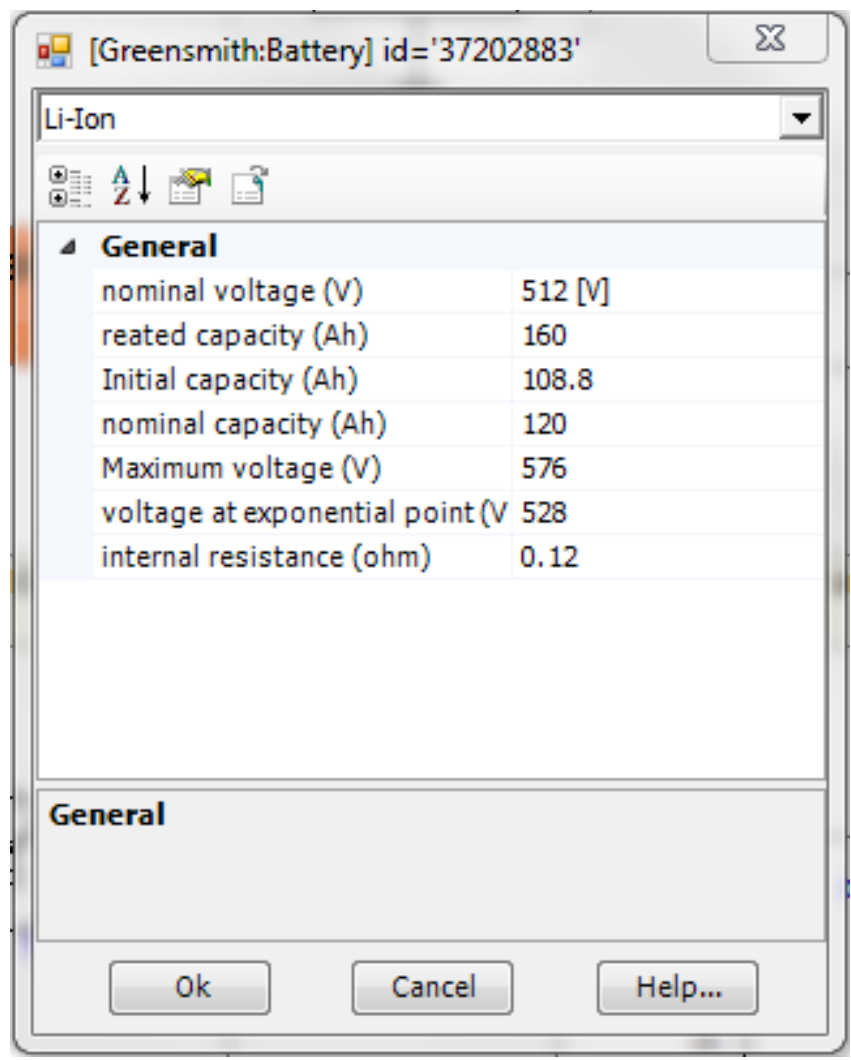

Figure 4-23: Greensmith Battery Parameters

\subsection{Fixed Load}

To model the load of the building, a three-phase fixed load was used. Figure 4-24 below is the PSCAD library component of the fixed load component.

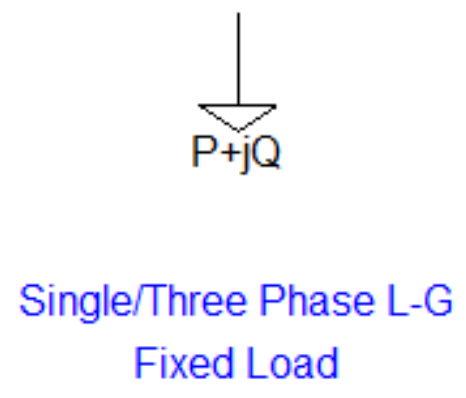

Figure 4-24: PSCAD Fixed Load Component

The fixed load component models the load characteristics as a function of voltage magnitude and frequency using the following characteristic equations: 


$$
\begin{aligned}
& P=P_{O} *\left(\frac{V}{V_{O}}\right)^{N P} *\left(1+K_{P F} * d F\right) \\
& Q=Q_{O} *\left(\frac{V}{V_{O}}\right)^{N Q} *\left(1+K_{Q F} * d F\right)
\end{aligned}
$$

Where:

- $\quad \mathrm{P}=$ Equivalent load real power

- $\mathrm{P}_{\mathrm{o}}=$ Rated real power per phase

- $\quad \mathrm{V}=$ Load voltage

- $\mathrm{V}_{\mathrm{o}}=$ Rated load voltage (RMS, L-G)

- $\quad \mathrm{NP}=\mathrm{dP} / \mathrm{dV}$ Voltage index for real power

- $\mathrm{K}_{\mathrm{PF}}=\mathrm{dP} / \mathrm{dF}$ Frequency index for real power

- $\mathrm{Q}=$ Equivalent load reactive power

- $\mathrm{Q}_{\mathrm{o}}=$ Rated reactive power (+inductive) per phase

- $\mathrm{NQ}=\mathrm{dQ} / \mathrm{dV}$ Voltage index for reactive power

- $\mathrm{K}_{\mathrm{QF}}=\mathrm{dQ} / \mathrm{dF}$ Frequency index for reactive power

NOTE: $d Q, d P, d V$, and $d F$ are all in per-unit quantities

In order to model a constant power load, set $\mathrm{NP}=\mathrm{NQ}=\mathrm{K}_{\mathrm{PF}}=\mathrm{K}_{\mathrm{QF}}=0$. This will simplify the original characteristic equations to:

$$
\begin{aligned}
& P=P_{O} \\
& Q=Q_{O}
\end{aligned}
$$

In order to model a constant impedance load, set $\mathrm{NP}=\mathrm{NQ}=2$ and $\mathrm{K}_{\mathrm{PF}}=\mathrm{K}_{\mathrm{QF}}=0$. This will simplify the original characteristic equations to: 


$$
\begin{aligned}
& P=P_{O} *\left(\frac{V}{V_{O}}\right)^{2} \\
& Q=Q_{O} *\left(\frac{V}{V_{O}}\right)^{2}
\end{aligned}
$$

For the purposes of this study, the loads were set up as constant power loads.

Figure 4-25 is an example of the fixed load parameters set up in PSCAD.

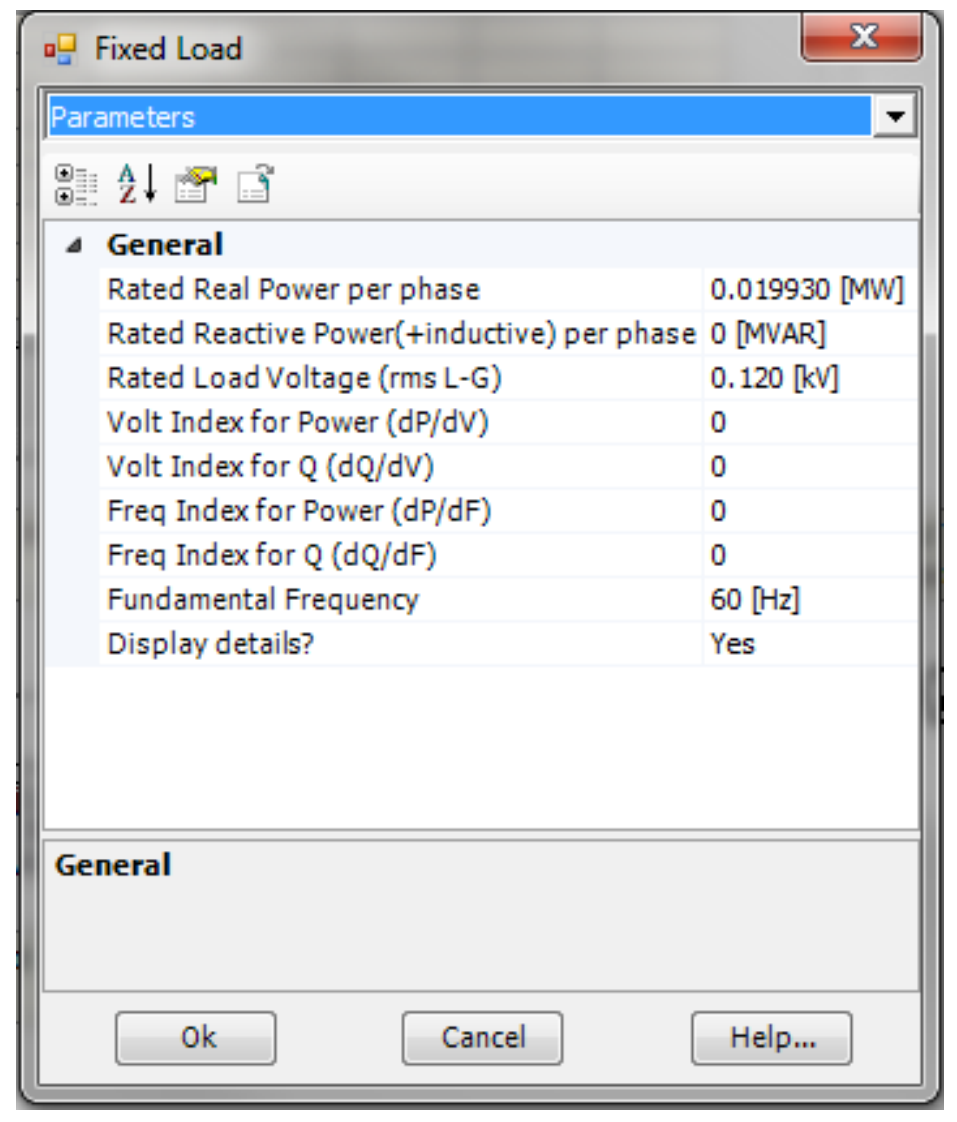

Figure 4-25: Fixed Load Parameters

\subsection{The Complete System}

All of the components previously described were combined to model the complete Greensmith DESS. The most common way of adding a battery to a PV system is to couple it on the DC side. Figure 4-26 shows a block diagram of a DC-coupled 
battery-backup grid-connected PV system [18]. The DC-coupled battery is attached between the charge controller and the inverter.

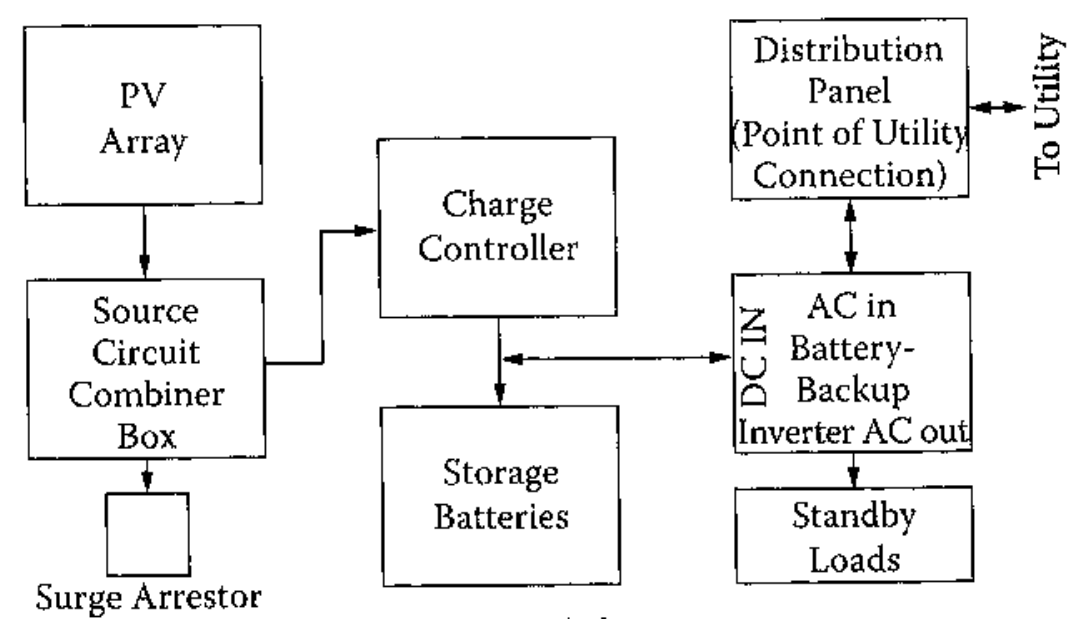

Figure 4-26: DC-Coupled Battery Backup System

A DC-coupled battery-backup system is the basis for the PSCAD Greensmith simulation circuit. Figure 4-27 shows the complete PSCAD model of the Greensmith system. The battery is DC-coupled between the DC-DC converter and the inverter. The output of the inverter is attached to the equivalent feeder circuit. The three-phase fixed load is attached at the output of the inverter which is on the secondary side of the stepdown transformer. 


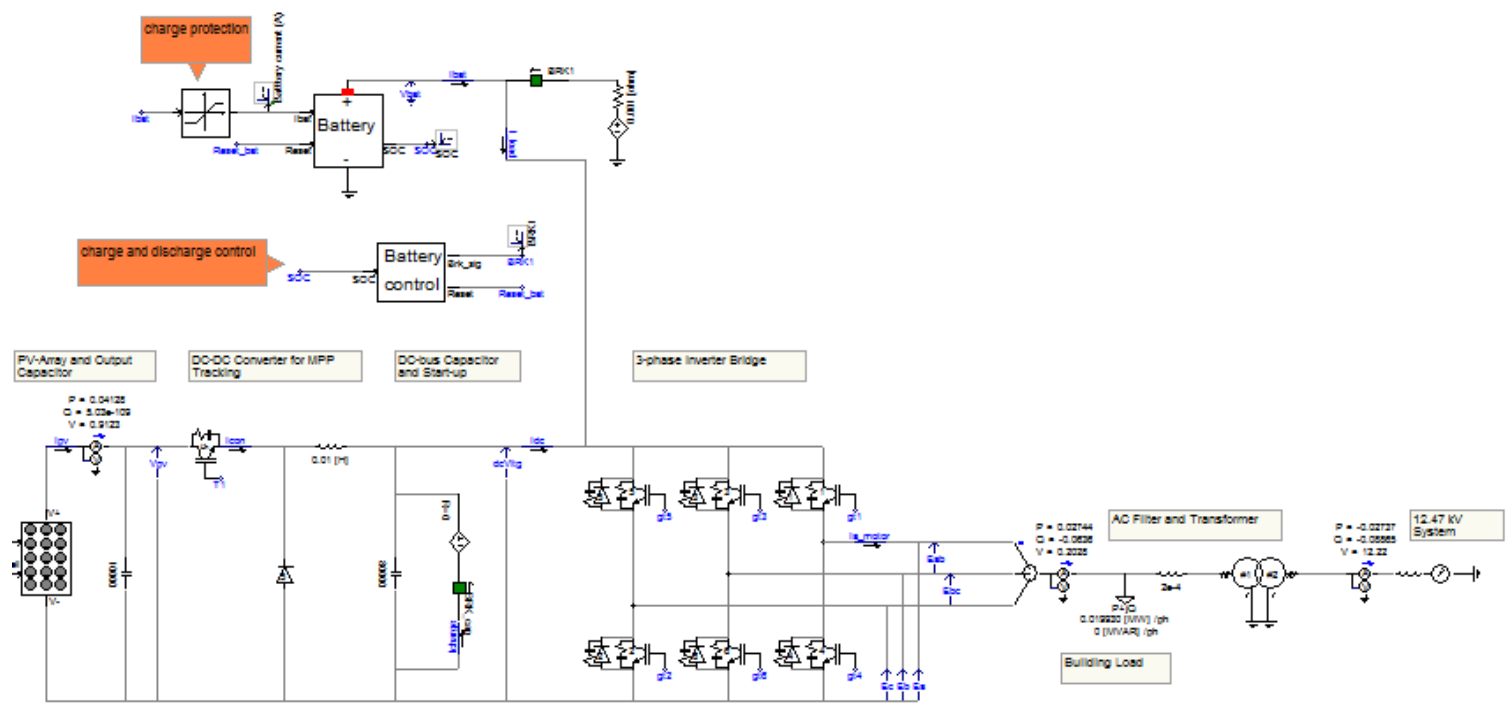

Figure 4-27: Complete Greensmith DESS PSCAD Model

The secondary side is attached to the primary through a three-phase two-winding Y-Y transformer. The secondary and primary line-line RMS voltages are $208 \mathrm{~V}$ and $12.47 \mathrm{kV}$, respectively. Figure 4-28 shows the transformer's winding voltages in its dialog box. 


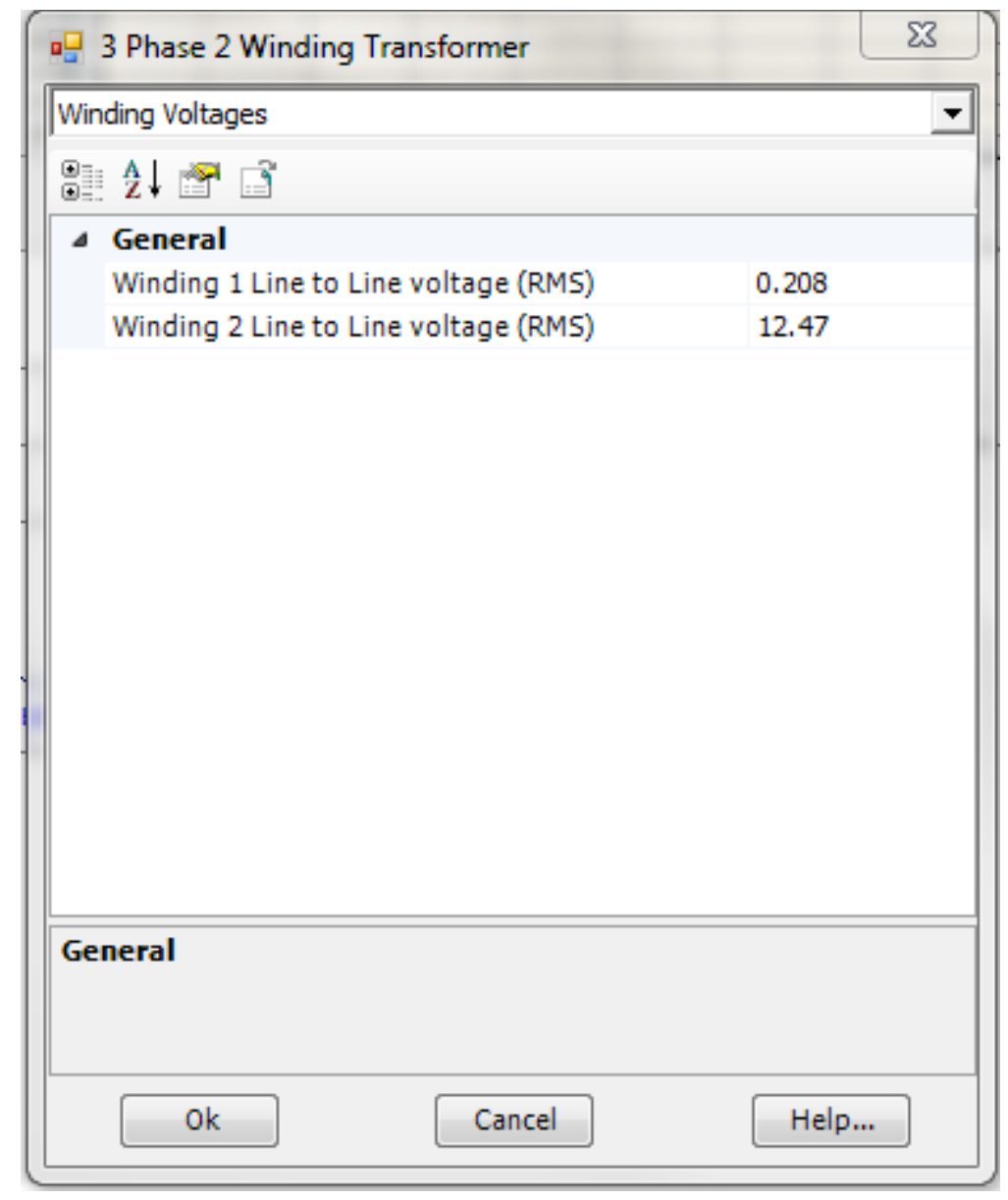

Figure 4-28: Transformer Winding Voltages

The primary side of the transformer is connected to the source of the system. The system's source is a three-phase, $60 \mathrm{~Hz}$, AC voltage source with a line-line RMS voltage of $12.47 \mathrm{kV}$. It has a behind-the-source inductive impedance of $0.1 \mathrm{H}$. Figure 4-29 displays the signal parameters of the voltage source. 


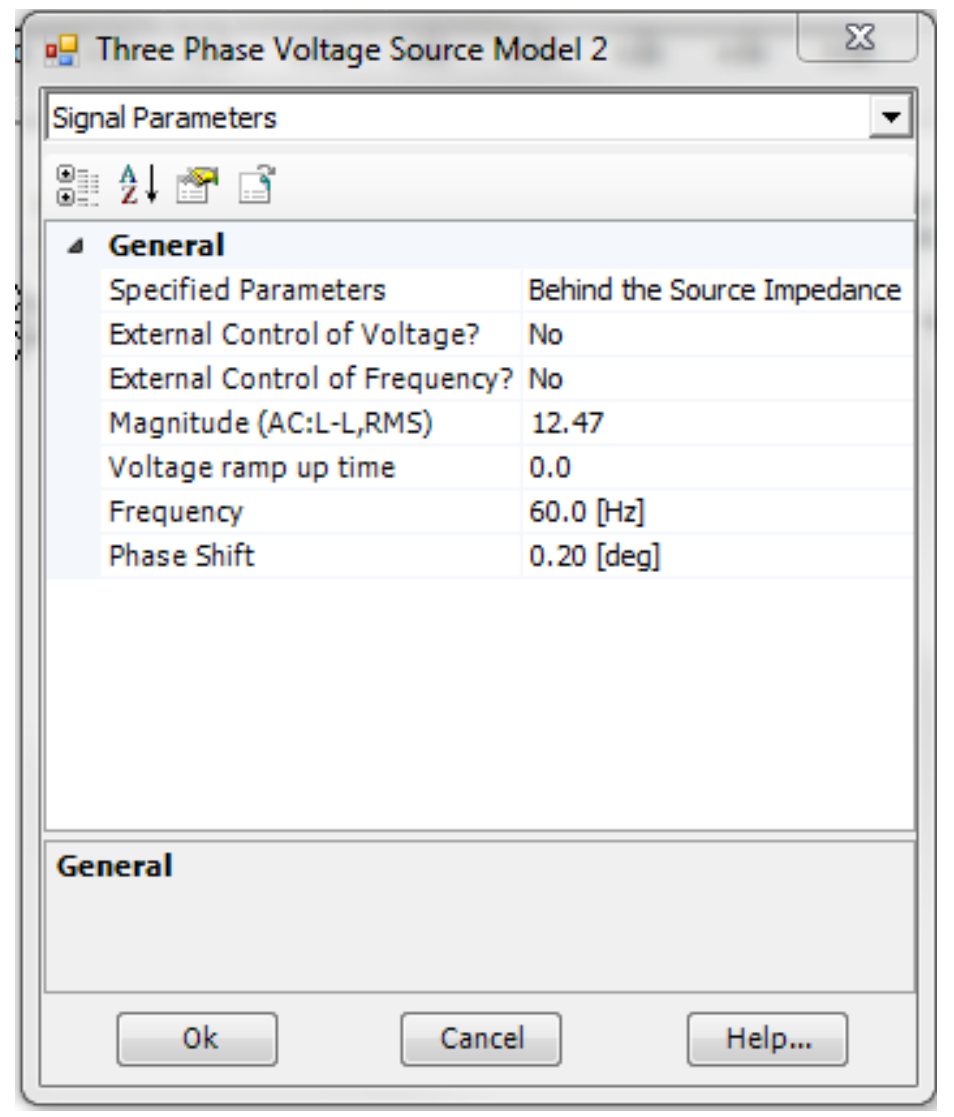

Figure 4-29: Three-Phase Voltage Source Signal Parameters

In the next chapter tests are conducted on the PSCAD system to see if it accurately models the real-world Greensmith system. 


\section{SYSTEM VALIDATION}

In order to validate the PSCAD model, tests were performed on the system to see if it could accurately represent the behavior of the Greensmith DESS. These tests include a validation of the MPPT's functionality as well as a full system test.

\subsection{MPPT Validation}

One way to boost power generation from a PV array is to use a Maximum Power Point Tracker (MPPT). In order for a MPPT to be useful it must be able to boost power generation for any input conditions. In this test the model from [12] is tested on its own without the battery or load attached. PVeducation.org has an applet that, based on the latitude of a location and the day of the year, calculates the daily solar irradiance. The latitude of San Diego, California is $32^{\circ} \mathrm{N}$ and date used was August $24^{\text {th }}$, corresponding to the date of when the SDG\&E data was collected. The generated daily solar irradiance in San Diego on August $24^{\text {th }}$ can be seen below in Figure 5-1 [19]. 


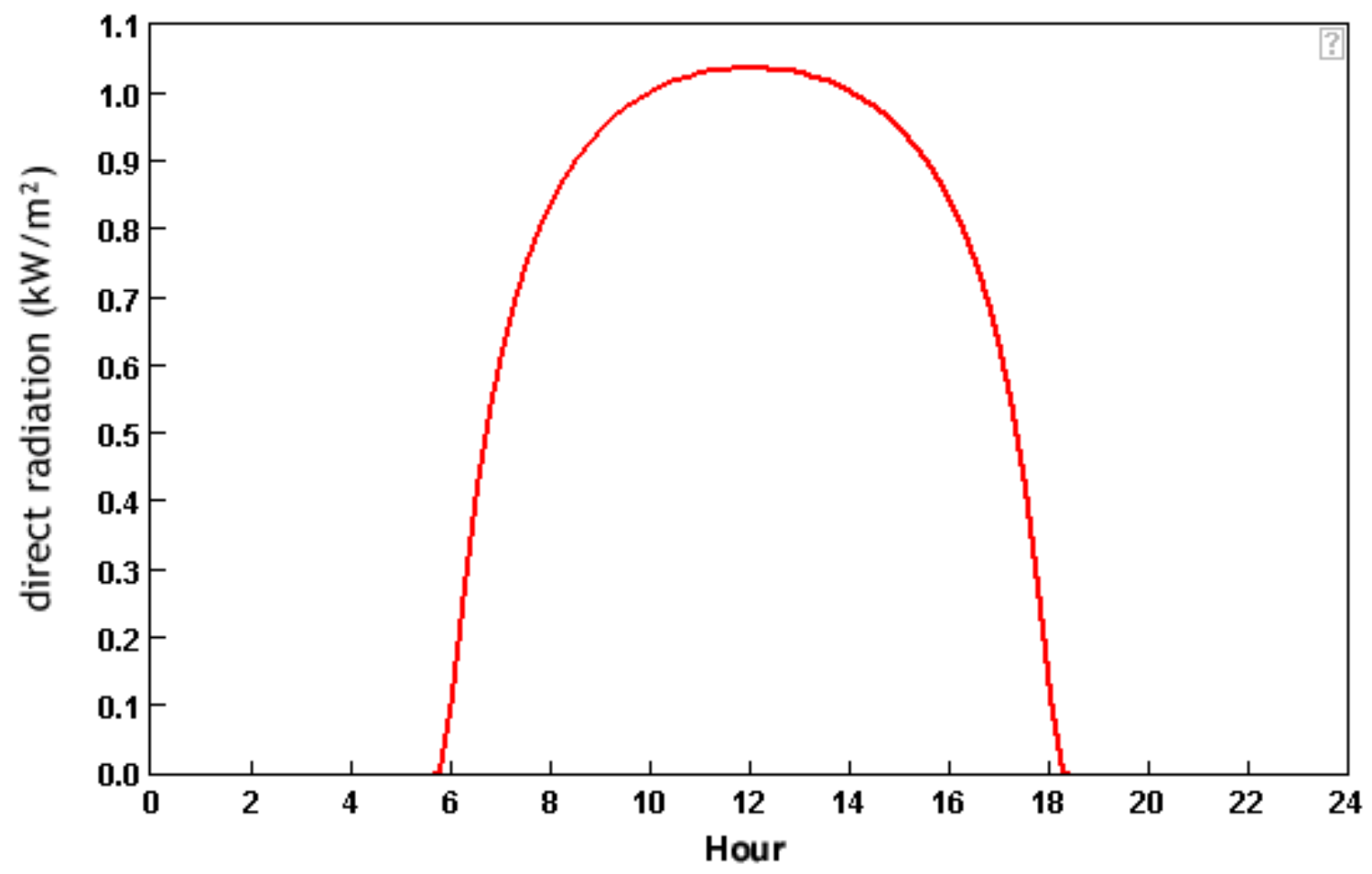

\section{Total Sunlight}

\begin{tabular}{|c|c|c|c|c|}
\hline Latitude & S & 32 deg north & N \\
\hline Date & Jan & Aug 24 & Dec \\
\hline
\end{tabular}

Figure 5-1: Daily Solar Irradiance in San Diego on August $24^{\text {th }}$

PVeducation.org allows the extraction of data points at every 15 minutes of the graph. The data collected from SDG\&E was only in the range of 10 A.M. to 3 P.M. Therefore, to correspond with the data from SDG\&E, the data points from Figure 5-1 in the range of 10 A.M. to 3 P.M. were tabulated below in the first two columns of Table 51. The insolation points in this range are plotted in the graph of Figure 5-2. 
Table 5-1: MPPT Test Data

\begin{tabular}{|c|c|c|c|}
\hline & & MPPT ON & MPPT OFF \\
\hline Time (Hour) & Insolation (W/m^2) & PV Power (W) & PV Power (W) \\
\hline 10 & 1005.739 & 40430 & 37740 \\
\hline 10.25 & 1014.809 & 40890 & 38010 \\
\hline 10.5 & 1022.372 & 41190 & 38300 \\
\hline 10.75 & 1028.566 & 41530 & 38550 \\
\hline 11 & 1033.5 & 41640 & 38740 \\
\hline 11.25 & 1037.257 & 41730 & 38930 \\
\hline 11.5 & 1039.899 & 41860 & 39000 \\
\hline 11.75 & 1041.467 & 41960 & 39060 \\
\hline 12 & 1041.987 & 41980 & 39080 \\
\hline 12.25 & 1041.467 & 41960 & 39060 \\
\hline 12.5 & 1039.899 & 41860 & 39000 \\
\hline 12.75 & 1037.257 & 41730 & 38930 \\
\hline 13 & 1033.5 & 41640 & 38740 \\
\hline 13.25 & 1028.566 & 41530 & 38550 \\
\hline 13.5 & 1022.372 & 41190 & 38300 \\
\hline 13.75 & 1014.809 & 40890 & 38010 \\
\hline 14 & 1005.739 & 40430 & 37740 \\
\hline 14.25 & 994.9896 & 40050 & 37290 \\
\hline 14.5 & 982.3408 & 39530 & 36820 \\
\hline 14.75 & 967.5186 & 39050 & 36290 \\
\hline 15 & 950.1771 & 38280 & 35640 \\
\hline
\end{tabular}




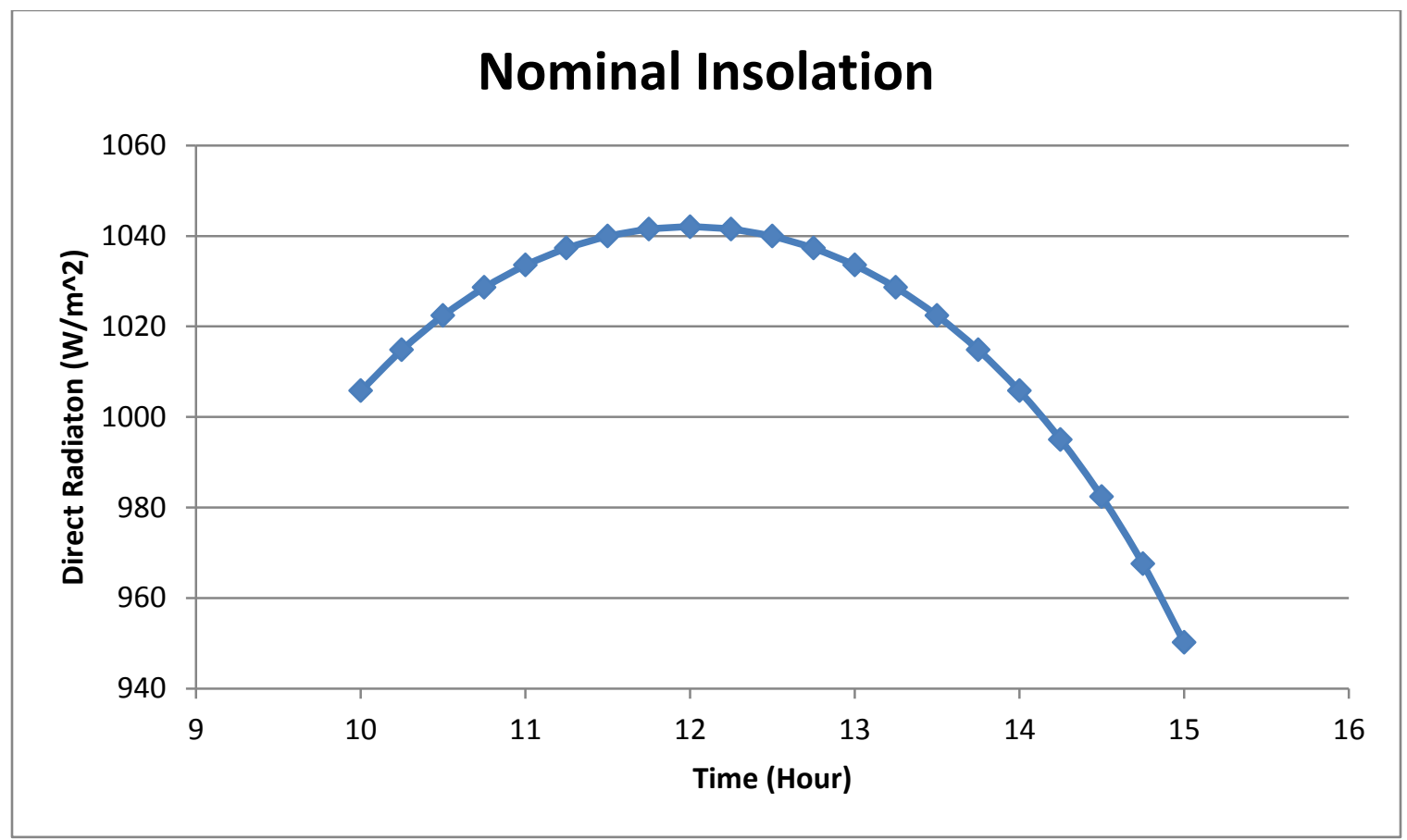

Figure 5-2: Nominal San Diego, CA Insolation on Aug. $24^{\text {th }}$ from 10 A.M. -3 P.M.

For every 15 minute point in the range, the corresponding insolation value was entered into the control panel for the PV array. For this test the temperature is held constant at $30^{\circ} \mathrm{C} / 86^{\circ} \mathrm{F}$. The $\mathrm{PV}$ array is set up as a $50 \mathrm{~kW}$ array. A multimeter is used to measure the instantaneous power from the PV array. The instantaneous power is measured with both the MPPT on and the MPPT off at every step. The tabulated MPPT on and off powers are shown in Table 5-1. The plots of these two powers are shown in Figure 5-3. 


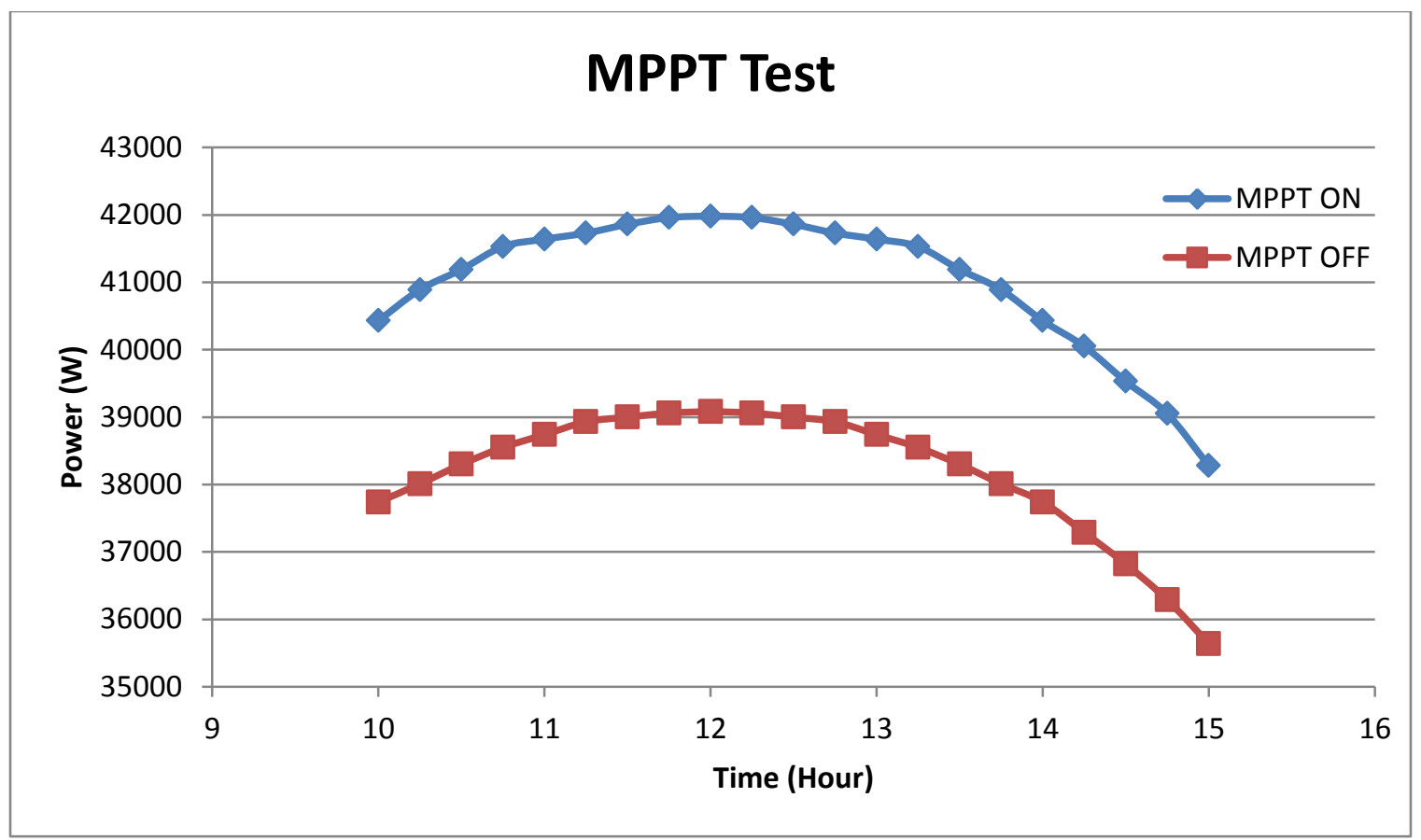

Figure 5-3: MPPT Validation Simulation

It can be seen in Figure 5-3 that at every time step the power generated with the MPPT on is greater than the power generated with the MPPT off. This test validates that the MPPT is able to boost the power output of the solar array.

\subsection{System Validation}

In order to test the full system, the entire spectrums of data from SDG\&E are considered. In the 10 A.M. to 3 P.M. time frame, experimental data were collected at every minute. For this simulation, the data at every 15 minute interval in that time frame are considered. Table 5-2 shows some of the data that were collected from the Greensmith system at every 15 minute interval. The data include the battery's SOC, cell temperature, and power. It also has the building's load as well as the amount of PV generated power. The last two columns are called the 'Load without Battery' and 'Net Load with Battery' and are formed from combinations of the other column values. 'Load 
without Battery' is the building load minus the PV power. 'Net Load with Battery' is the 'Load without Battery' value added to the battery power.

Table 5-2: SDG\&E Greensmith Data

\begin{tabular}{|c|c|c|c|c|c|c|c|}
\hline $\begin{array}{l}\text { Recorded } \\
\text { Time }\end{array}$ & $\begin{array}{c}\text { State of } \\
\text { Charge }\end{array}$ & $\begin{array}{l}\text { Cell } \\
\text { Temp. }\end{array}$ & $\begin{array}{c}\text { Battery } \\
\text { Power(W) }\end{array}$ & $\begin{array}{l}\text { Building } \\
\text { Load(W) }\end{array}$ & $\begin{array}{l}\text { PV Power } \\
\text { Output(W) }\end{array}$ & $\begin{array}{c}\text { Load Without } \\
\text { Battery (W) }\end{array}$ & $\begin{array}{c}\text { Net Load With } \\
\text { Battery (W) }\end{array}$ \\
\hline $\begin{array}{c}8 / 24 / 2011 \\
10: 01\end{array}$ & 49 & 27.2125 & 35600 & 55970 & 37055 & 18915 & 54515 \\
\hline $\begin{array}{c}8 / 24 / 2011 \\
10: 15\end{array}$ & 58 & 28.80625 & 33100 & 54770 & 38225 & 16545 & 49645 \\
\hline $\begin{array}{c}8 / 24 / 2011 \\
10: 30 \\
\end{array}$ & 65 & 29.69375 & 17100 & 60580 & 38552 & 22028 & 39128 \\
\hline $\begin{array}{c}8 / 24 / 2011 \\
10: 45\end{array}$ & 68 & 30.075 & 6100 & 64370 & 39887 & 24483 & 30583 \\
\hline $\begin{array}{c}8 / 24 / 2011 \\
11: 00 \\
\end{array}$ & 68 & 30.425 & 1100 & 59790 & 41401 & 18389 & 19489 \\
\hline $\begin{array}{c}8 / 24 / 2011 \\
11: 15\end{array}$ & 67 & 30.7625 & 1100 & 62930 & 42396 & 20534 & 21634 \\
\hline $\begin{array}{c}8 / 24 / 2011 \\
11: 30 \\
\end{array}$ & 64 & 30.99375 & 2100 & 67810 & 43556 & 24254 & 26354 \\
\hline $\begin{array}{c}8 / 24 / 2011 \\
11: 45\end{array}$ & 63 & 31.1875 & 100 & 68850 & 41531 & 27319 & 27419 \\
\hline $\begin{array}{c}8 / 24 / 2011 \\
12: 00\end{array}$ & 61 & 31.35 & 100 & 72180 & 41290 & 30890 & 30990 \\
\hline $\begin{array}{c}8 / 24 / 2011 \\
12: 15\end{array}$ & 61 & 31.46875 & 600 & 73480 & 42130 & 31350 & 31950 \\
\hline $\begin{array}{c}8 / 24 / 2011 \\
12: 31 \\
\end{array}$ & 59 & 31.66875 & -900 & 66910 & 40270 & 26640 & 25740 \\
\hline $\begin{array}{c}8 / 24 / 2011 \\
12: 45 \\
\end{array}$ & 57 & 31.81875 & -12500 & 67480 & 24537 & 42943 & 30443 \\
\hline $\begin{array}{c}8 / 24 / 2011 \\
13: 00\end{array}$ & 51 & 32.19375 & 600 & 74860 & 42149 & 32711 & 33311 \\
\hline $\begin{array}{c}8 / 24 / 2011 \\
13: 15 \\
\end{array}$ & 46 & 32.49375 & -22000 & 65170 & 17594 & 47576 & 25576 \\
\hline $\begin{array}{c}8 / 24 / 2011 \\
13: 30\end{array}$ & 45 & 32.425 & 4100 & 68940 & 39488 & 29452 & 33552 \\
\hline $\begin{array}{c}8 / 24 / 2011 \\
13: 45\end{array}$ & 44 & 32.575 & -25800 & 67870 & 8318 & 59552 & 33752 \\
\hline $\begin{array}{c}8 / 24 / 2011 \\
14: 00\end{array}$ & 44 & 32.825 & 13600 & 68370 & 41510 & 26860 & 40460 \\
\hline $\begin{array}{c}8 / 24 / 2011 \\
14: 15\end{array}$ & 43 & 32.9875 & 100 & 63910 & 26974 & 36936 & 37036 \\
\hline $\begin{array}{c}8 / 24 / 2011 \\
14: 30\end{array}$ & 42 & 33.175 & 14100 & 61310 & 34991 & 26319 & 40419 \\
\hline $\begin{array}{c}8 / 24 / 2011 \\
14: 45\end{array}$ & 44 & 33.56875 & -20300 & 64970 & 0 & 64970 & 44670 \\
\hline $\begin{array}{c}8 / 24 / 2011 \\
14: 59\end{array}$ & 38 & 33.825 & -4400 & 60100 & 8408 & 51692 & 47292 \\
\hline
\end{tabular}

The SDG\&E data are used to define the specifications of the simulation model for each data point. First, it is desirable to recreate the PV power as closely as possible. To do this, the temperature of the $50 \mathrm{~kW} \mathrm{PV}$ array model is set to the same temperature as 
the Cell Temperature in Table 5-2. Next, the radiation level is adjusted until the array produces a power output that is as close to the experimental value as possible. The MPPT in the simulation is used at all times in order to replicate the actual model. Table 5-3 shows the input array temperature and solar radiation. The last two columns are the simulation's PV power output measured with a multimeter and the experimental PV power output.

Table 5-3: Solar Power Data

\begin{tabular}{|c|c|c|c|c|}
\hline $\begin{array}{l}\text { Recorded } \\
\text { Time }\end{array}$ & $\begin{array}{c}\text { PV Array } \\
\text { Temperature }\end{array}$ & $\begin{array}{c}\text { Solar } \\
\text { Radiation } \\
\left(\mathrm{W} / \mathrm{m}^{\wedge} 2\right)\end{array}$ & $\begin{array}{c}\text { Simulation PV } \\
\text { Power Output } \\
\text { (W) }\end{array}$ & $\begin{array}{c}\text { Experimental } \\
\text { PV Power } \\
\text { Output (W) }\end{array}$ \\
\hline $8 / 24 / 2011$ & & & & \\
\hline $10: 01$ & 27.2125 & 712 & 37050 & 37055 \\
\hline $8 / 24 / 2011$ & & & & \\
\hline $10: 15$ & 28.80625 & 748 & 38040 & 38225 \\
\hline $8 / 24 / 2011$ & & & & \\
\hline $10: 30$ & 29.69375 & 796 & 38500 & 38552 \\
\hline $8 / 24 / 2011$ & & & & \\
\hline $10: 45$ & 30.075 & 868 & 39860 & 39887 \\
\hline $8 / 24 / 2011$ & & & & \\
\hline $11: 00$ & 30.425 & 904 & 41280 & 41401 \\
\hline $8 / 24 / 2011$ & & & & \\
\hline $11: 15$ & 30.7625 & 904 & 42300 & 42396 \\
\hline $8 / 24 / 2011$ & & & & \\
\hline $11: 30$ & 30.99375 & 892 & 43480 & 43556 \\
\hline $8 / 24 / 2011$ & & & & \\
\hline $11: 45$ & 31.1875 & 844 & 41530 & 41531 \\
\hline $8 / 24 / 2011$ & & & & \\
\hline $12: 00$ & 31.35 & 832 & 41580 & 41290 \\
\hline $8 / 24 / 2011$ & 31.46875 & 844 & 42170 & 42130 \\
\hline
\end{tabular}




\begin{tabular}{|c|c|c|c|c|}
\hline $12: 15$ & & & & \\
\hline $8 / 24 / 2011$ & & & & \\
\hline $12: 31$ & 31.66875 & 796 & 40290 & 40270 \\
\hline $8 / 24 / 2011$ & & & & \\
\hline $12: 45$ & 31.81875 & 472 & 24400 & 24537 \\
\hline $8 / 24 / 2011$ & & & & \\
\hline $13: 00$ & 32.19375 & 808 & 41970 & 42149 \\
\hline $8 / 24 / 2011$ & & & & \\
\hline $13: 15$ & 32.49375 & 340 & 17810 & 17594 \\
\hline $8 / 24 / 2011$ & & & & \\
\hline $13: 30$ & 32.425 & 760 & 39680 & 39488 \\
\hline $8 / 24 / 2011$ & & & & \\
\hline $13: 45$ & 32.575 & 160 & 8366 & 8318 \\
\hline $8 / 24 / 2011$ & & & & \\
\hline $14: 00$ & 32.825 & 796 & 41550 & 41510 \\
\hline $8 / 24 / 2011$ & & & & \\
\hline $14: 15$ & 32.9875 & 520 & 27180 & 26974 \\
\hline $8 / 24 / 2011$ & & & & \\
\hline $14: 30$ & 33.175 & 676 & 35290 & 34991 \\
\hline $8 / 24 / 2011$ & & & & \\
\hline $14: 45$ & 33.56875 & 0 & 0 & 0 \\
\hline $8 / 24 / 2011$ & & & & \\
\hline $14: 59$ & 33.825 & 160 & 8344 & 8408 \\
\hline
\end{tabular}

Figure 5-4 is a graph of the experimental and simulation PV powers. The two PV powers are nearly identical at each point. 


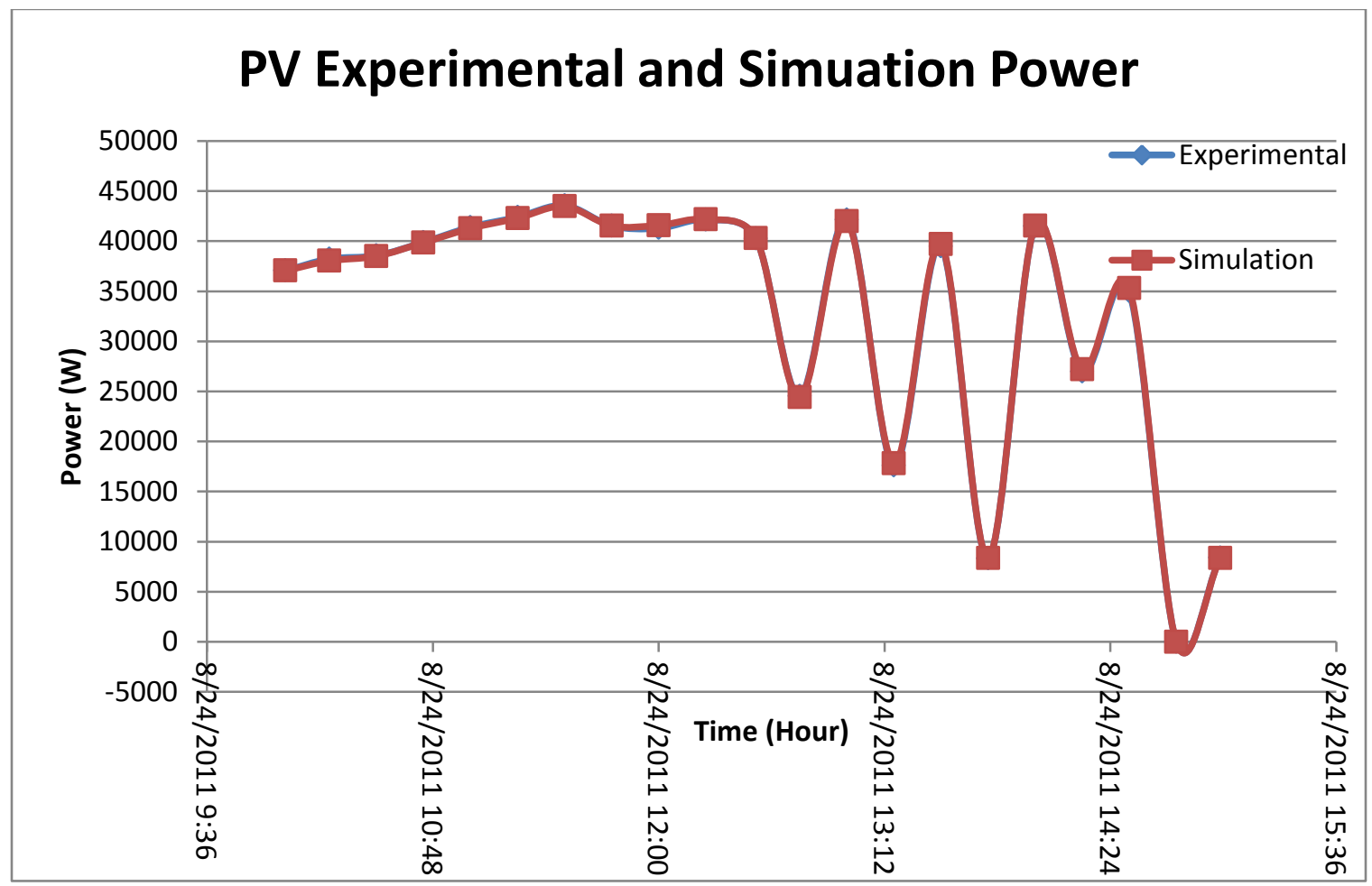

Figure 5-4: PV Experimental and Simulation Power

After the proper simulation PV power is achieved, the building load is the next to be set up. The building load is modeled as a three-phase fixed load on the secondary of the transformer. The fixed load is modeled as a constant power load. Since the threephase fixed load parameters are defined as the rated real power per phase, the experimental building load is divided by three for this parameter. This is necessary to represent the per-phase load. When all three phases of the load are combined they represent the complete building load. Table 5-4 shows the complete building load and its per-phase value used in the three-phase fixed load parameters. 
Table 5-4: Building Load Data

\begin{tabular}{|c|c|c|}
\hline Recorded Time & Building Load(W) & Building Load/ph (W) \\
\hline $8 / 24 / 201110: 01$ & 55970 & 18656.66667 \\
\hline $8 / 24 / 201110: 15$ & 54770 & 18256.66667 \\
\hline $8 / 24 / 201110: 30$ & 60580 & 20193.33333 \\
\hline $8 / 24 / 201110: 45$ & 64370 & 21456.66667 \\
\hline $8 / 24 / 201111: 00$ & 59790 & 19930 \\
\hline $8 / 24 / 201111: 15$ & 62930 & 20976.66667 \\
\hline $8 / 24 / 201111: 30$ & 67810 & 22603.33333 \\
\hline $8 / 24 / 201111: 45$ & 68850 & 22950 \\
\hline $8 / 24 / 201112: 00$ & 72180 & 24060 \\
\hline $8 / 24 / 201112: 15$ & 73480 & 24493.33333 \\
\hline $8 / 24 / 201112: 31$ & 66910 & 22303.33333 \\
\hline $8 / 24 / 201112: 45$ & 67480 & 22493.33333 \\
\hline $8 / 24 / 201113: 00$ & 74860 & 24953.33333 \\
\hline $8 / 24 / 201113: 15$ & 65170 & 21723.33333 \\
\hline $8 / 24 / 201113: 30$ & 68940 & 22980 \\
\hline $8 / 24 / 201113: 45$ & 67870 & 22623.33333 \\
\hline $8 / 24 / 201114: 00$ & 68370 & 22790 \\
\hline $8 / 24 / 201114: 15$ & 63910 & 21303.33333 \\
\hline $8 / 24 / 201114: 30$ & 61310 & 20436.66667 \\
\hline $8 / 24 / 201114: 45$ & 64970 & 21656.66667 \\
\hline $8 / 24 / 201114: 59$ & 60100 & 20033.33333 \\
\hline
\end{tabular}

The final parameter that is varied for the simulation is the battery's state of charge. In the PSCAD battery's parameters the state of charge is represented as the initial capacity (Ah). Since the rated capacity of the battery is $160 \mathrm{Ah}$, the initial capacity of the battery is the percentage SOC of the rated capacity. Table 5-5 shows the battery's SOC and its corresponding initial capacity. 
Table 5-5: Battery's Initial Capacity

\begin{tabular}{|c|c|c|}
\hline Recorded Time & State of Charge (\%) & Initial Capacity (Ah) \\
\hline $8 / 24 / 2011$ 10:01 & 49 & 78.4 \\
\hline $8 / 24 / 201110: 15$ & 58 & 92.8 \\
\hline $8 / 24 / 201110: 30$ & 65 & 104 \\
\hline $8 / 24 / 201110: 45$ & 68 & 108.8 \\
\hline $8 / 24 / 201111: 00$ & 68 & 108.8 \\
\hline $8 / 24 / 201111: 15$ & 67 & 107.2 \\
\hline $8 / 24 / 201111: 30$ & 64 & 102.4 \\
\hline $8 / 24 / 201111: 45$ & 63 & 100.8 \\
\hline $8 / 24 / 201112: 00$ & 61 & 97.6 \\
\hline $8 / 24 / 201112: 15$ & 61 & 97.6 \\
\hline $8 / 24 / 201112: 31$ & 59 & 94.4 \\
\hline $8 / 24 / 201112: 45$ & 57 & 91.2 \\
\hline $8 / 24 / 201113: 00$ & 51 & 81.6 \\
\hline $8 / 24 / 201113: 15$ & 46 & 73.6 \\
\hline $8 / 24 / 201113: 30$ & 45 & 72 \\
\hline $8 / 24 / 201113: 45$ & 44 & 70.4 \\
\hline $8 / 24 / 201114: 00$ & 44 & 70.4 \\
\hline $8 / 24 / 201114: 15$ & 43 & 68.8 \\
\hline $8 / 24 / 201114: 30$ & 42 & 67.2 \\
\hline $8 / 24 / 201114: 45$ & 44 & 70.4 \\
\hline $8 / 24 / 201114: 59$ & 38 & 60.8 \\
\hline
\end{tabular}

Table 5-6 is a summary of all the input conditions used for the test simulation of the Greensmith system. 
Table 5-6: Summary of Simulation Inputs

\begin{tabular}{|c|c|c|c|c|}
\hline $\begin{array}{l}\text { Recorded } \\
\text { Time }\end{array}$ & $\begin{array}{l}\text { Building Load/ph } \\
\text { (W) }\end{array}$ & $\begin{array}{c}\text { PV Array } \\
\text { Temperature }\end{array}$ & $\begin{array}{l}\text { Initial Capacity } \\
\text { (Ah) }\end{array}$ & $\begin{array}{c}\text { Solar Radiation } \\
\left(W / m^{\wedge} 2\right)\end{array}$ \\
\hline $\begin{array}{c}8 / 24 / 2011 \\
10: 01\end{array}$ & 18656.66667 & 27.2125 & 78.4 & 712 \\
\hline $\begin{array}{c}8 / 24 / 2011 \\
10: 15\end{array}$ & 18256.66667 & 28.80625 & 92.8 & 748 \\
\hline $\begin{array}{c}8 / 24 / 2011 \\
10: 30\end{array}$ & 20193.33333 & 29.69375 & 104 & 796 \\
\hline $\begin{array}{c}8 / 24 / 2011 \\
10: 45\end{array}$ & 21456.66667 & 30.075 & 108.8 & 868 \\
\hline $\begin{array}{c}8 / 24 / 2011 \\
11: 00 \\
\end{array}$ & 19930 & 30.425 & 108.8 & 904 \\
\hline $\begin{array}{c}8 / 24 / 2011 \\
11: 15\end{array}$ & 20976.66667 & 30.7625 & 107.2 & 904 \\
\hline $\begin{array}{c}8 / 24 / 2011 \\
11: 30\end{array}$ & 22603.33333 & 30.99375 & 102.4 & 892 \\
\hline $\begin{array}{c}8 / 24 / 2011 \\
11: 45\end{array}$ & 22950 & 31.1875 & 100.8 & 844 \\
\hline $\begin{array}{c}8 / 24 / 2011 \\
12: 00\end{array}$ & 24060 & 31.35 & 97.6 & 832 \\
\hline $\begin{array}{c}8 / 24 / 2011 \\
12: 15\end{array}$ & 24493.33333 & 31.46875 & 97.6 & 844 \\
\hline $\begin{array}{c}8 / 24 / 2011 \\
12: 31\end{array}$ & 22303.33333 & 31.66875 & 94.4 & 796 \\
\hline $\begin{array}{c}8 / 24 / 2011 \\
12: 45\end{array}$ & 22493.33333 & 31.81875 & 91.2 & 472 \\
\hline $\begin{array}{c}8 / 24 / 2011 \\
13: 00\end{array}$ & 24953.33333 & 32.19375 & 81.6 & 808 \\
\hline $\begin{array}{c}8 / 24 / 2011 \\
13: 15\end{array}$ & 21723.33333 & 32.49375 & 73.6 & 340 \\
\hline $\begin{array}{c}8 / 24 / 2011 \\
13: 30\end{array}$ & 22980 & 32.425 & 72 & 760 \\
\hline $\begin{array}{c}8 / 24 / 2011 \\
13: 45\end{array}$ & 22623.33333 & 32.575 & 70.4 & 160 \\
\hline $\begin{array}{c}8 / 24 / 2011 \\
14: 00\end{array}$ & 22790 & 32.825 & 70.4 & 796 \\
\hline $\begin{array}{c}8 / 24 / 2011 \\
14: 15\end{array}$ & 21303.33333 & 32.9875 & 68.8 & 520 \\
\hline $\begin{array}{c}8 / 24 / 2011 \\
14: 30\end{array}$ & 20436.66667 & 33.175 & 67.2 & 676 \\
\hline $\begin{array}{c}8 / 24 / 2011 \\
14: 45 \\
\end{array}$ & 21656.66667 & 33.56875 & 70.4 & 0 \\
\hline $\begin{array}{c}8 / 24 / 2011 \\
14: 59\end{array}$ & 20033.33333 & 33.825 & 60.8 & 160 \\
\hline
\end{tabular}


The instantaneous power flow is measured at the source of the equivalent system using a multimeter. The power delivered from the source represents the loading of the entire Greensmith system on the feeder's circuit including the AC filter and transformer. Figure 5-5 is an example of a multimeter measurement at the system equivalent.

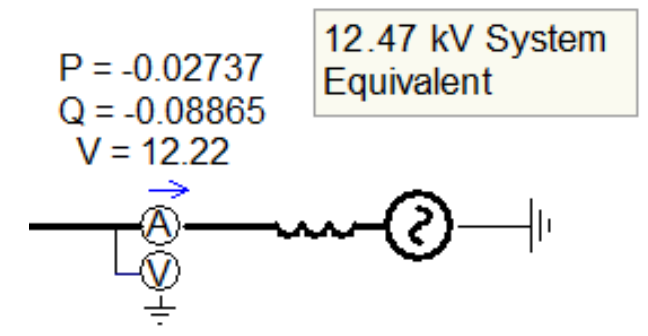

Figure 5-5: Power Measurement at System Equivalent

The real power and line-line RMS voltage of the multimeter were collected at each point. The power measured is equivalent to the net load with the battery attached. The power values are considered as the power delivered to the load side. The results are shown in Table 5-7. 
Table 5-7: Simulation Results

\begin{tabular}{|c|c|c|}
\hline Recorded Time & Net Load with Battery $\mathbf{( W )}$ & Line-Line $\mathbf{V}_{\text {RMS }} \mathbf{( k V )}$ \\
\hline $8 / 24 / 2011$ 10:01 & 20420 & 11.51 \\
\hline $8 / 24 / 201110: 15$ & 22030 & 11.67 \\
\hline $8 / 24 / 201110: 30$ & 24750 & 11.94 \\
\hline $8 / 24 / 201110: 45$ & 27170 & 12.19 \\
\hline $8 / 24 / 201111: 00$ & 27370 & 12.22 \\
\hline $8 / 24 / 201111: 15$ & 26320 & 12.1 \\
\hline $8 / 24 / 201111: 30$ & 24380 & 11.9 \\
\hline $8 / 24 / 201111: 45$ & 23890 & 11.85 \\
\hline $8 / 24 / 201112: 00$ & 23040 & 11.76 \\
\hline $8 / 24 / 201112: 15$ & 23050 & 11.77 \\
\hline $8 / 24 / 201112: 31$ & 22350 & 11.7 \\
\hline $8 / 24 / 201112: 45$ & 21200 & 11.58 \\
\hline $8 / 24 / 201113: 00$ & 20690 & 11.54 \\
\hline $8 / 24 / 201113: 15$ & 18370 & 11.48 \\
\hline $8 / 24 / 201113: 30$ & 20030 & 11.49 \\
\hline $8 / 24 / 201113: 45$ & 16980 & 11.47 \\
\hline $8 / 24 / 201114: 00$ & 19680 & 11.49 \\
\hline $8 / 24 / 201114: 15$ & 17960 & 11.48 \\
\hline $8 / 24 / 201114: 30$ & 18140 & 11.48 \\
\hline $8 / 24 / 201114: 45$ & 16690 & 11.47 \\
\hline $8 / 24 / 201114: 59$ & 17020 & 11.47 \\
\hline
\end{tabular}

Figure 5-6 is a graphical comparison of the experimental and simulation data. 


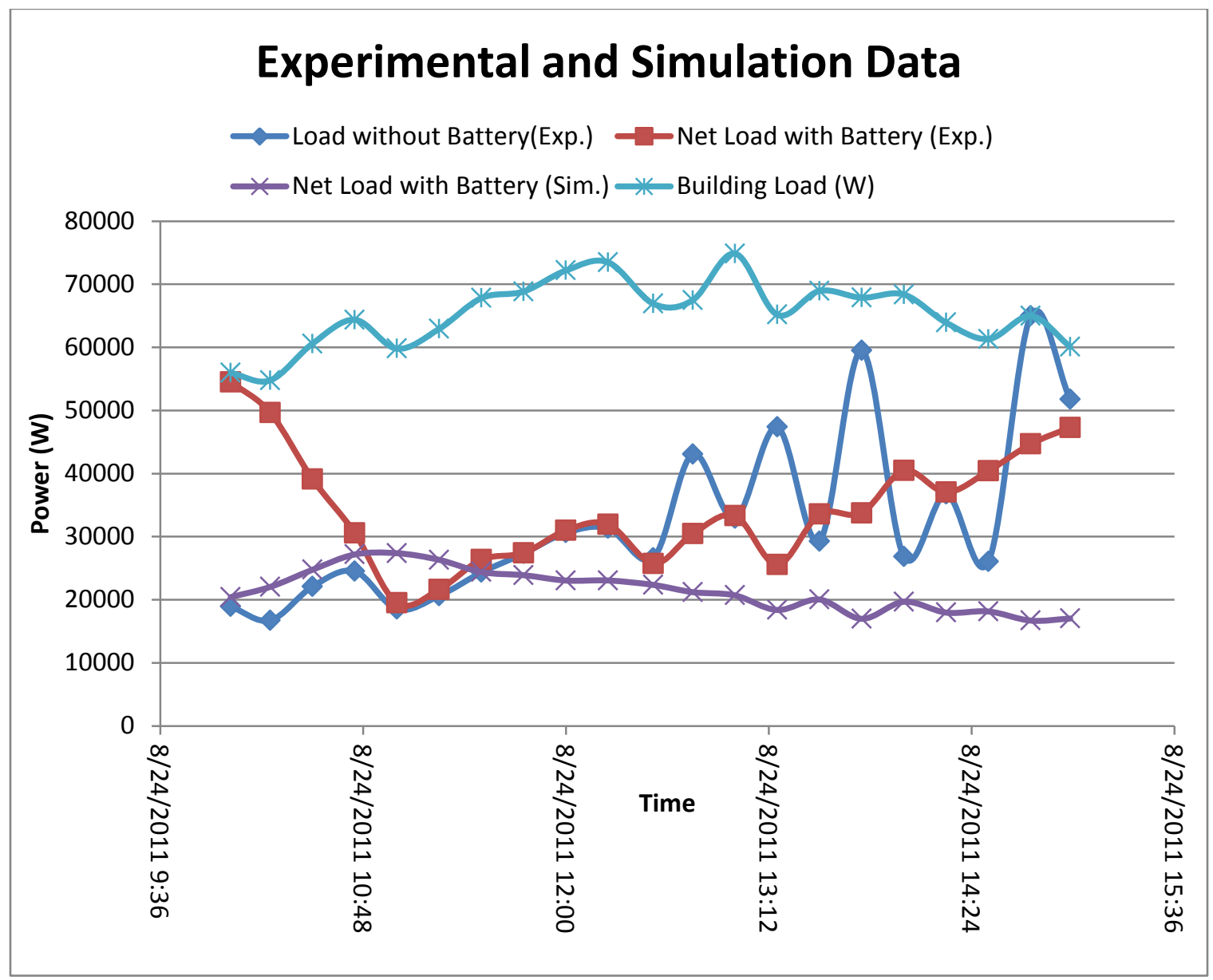

Figure 5-6: System Experimental and Simulation Data

The 'Building Load' is the load of the building on its own without any support from the PV or battery. The 'Load without Battery (Exp.)' is the building load minus the experimental PV power. This graph would be almost exactly the same if the simulation PV power were considered instead because the experimental and simulation PV outputs are nearly the same. The large swings in this plot's graph are due to the variability in the PV power. The 'Net Load with Battery (Exp.)' is the 'Load with Battery (Exp.)' graph with the experimental battery power added. This graph represents the net load that the rest of the feeder circuit sees. By comparing the 'Net Load with Battery (Exp.)' against the 'Load without Battery (Exp.),' it can be seen that the addition of the battery helps to 
smooth out the load profile considerably. The large swings that were present in the 'Load without Battery (Exp.)' plot are reduced in the 'Net Load with Battery (Exp.)' plot. The last plot on the graph is of the simulation of the 'Net Load with Battery (Sim.).' The 'Net Load with Battery (Sim.)' plot shows that the Greensmith simulation model achieves the goal of smoothing out the variability in the PV power while also lowering the building load. The reason that the experimental and simulation 'Net Load with Battery' plots do not exactly match is because the experimental system makes use of a battery management system that regulates the battery output based upon the instantaneous PV power. The simulation model of the system makes use of a battery controller that does not regulate the battery output based upon the PV power. Instead, the battery controller monitors the battery's SOC to determine whether the battery is in a charging or discharging state. Even without the battery management system, the simulation is still able to reduce the building load and smooth out the solar intermittency.

The voltage of the system is examined next. Table 5-7 has the simulated line-line RMS voltages measured at the multimeter. Figure 5-7 is a graph of these voltages over time. 


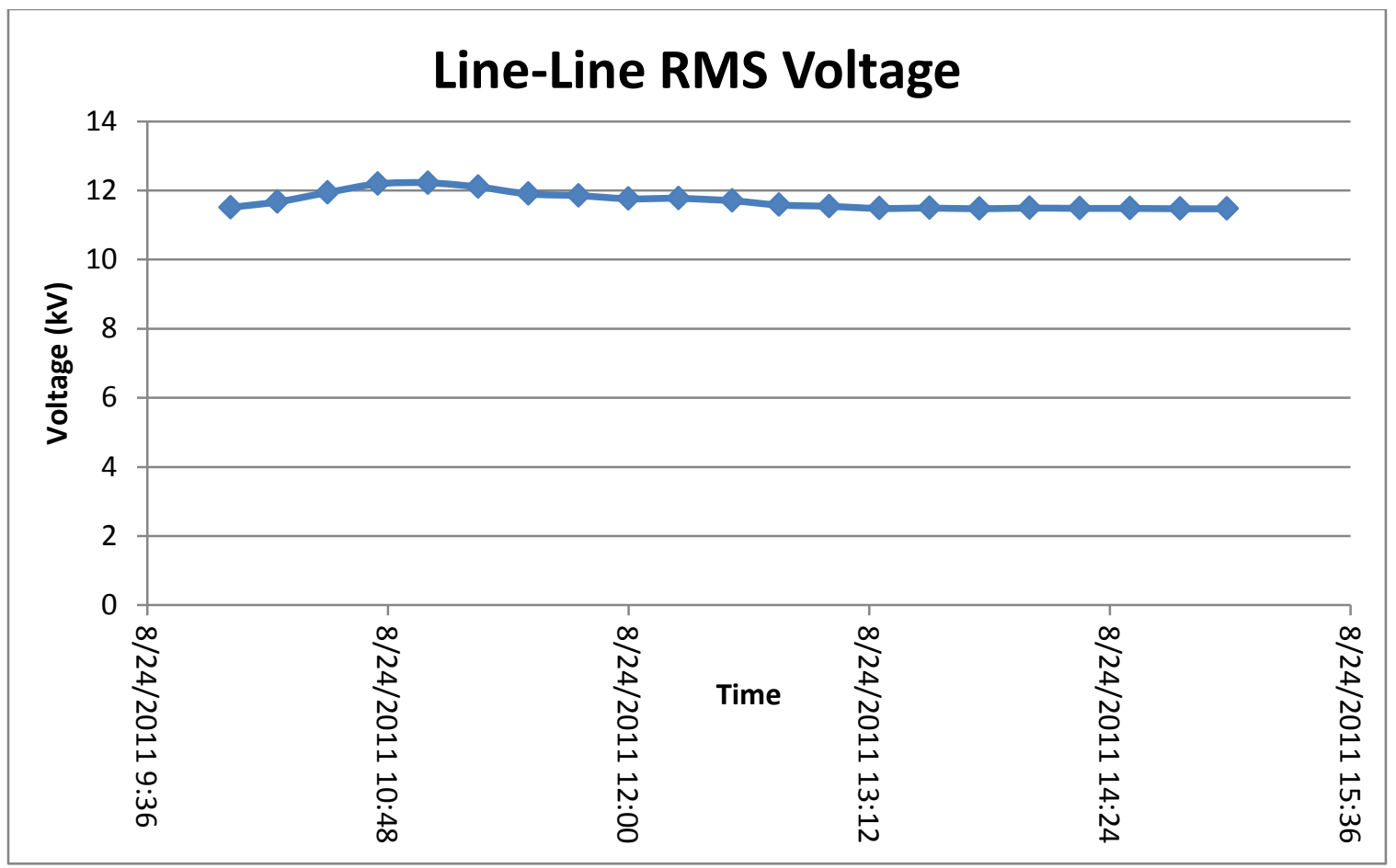

Figure 5-7: Line-Line RMS Voltage

The simulation is able to maintain a voltage that is close to the rated voltage of 12.47 $\mathrm{kV}$ throughout. The variation in the voltage can be attributed to the inverter which makes use of a simple inverter controller. The inverter is set to operate at unity power factor, but during the transients, the reactive power output of the inverter changes [12]. Figure 5-8 is an example of how the PCC responds to transients created by the solar variation [12]. The real power output changes proportional to the changes in the solar radiation level [12]. The reactive power changes when the real power changes, but settles back to zero in order to maintain a unity power factor. The PCC's nominal voltage is 11 $\mathrm{kV}[12]$. 


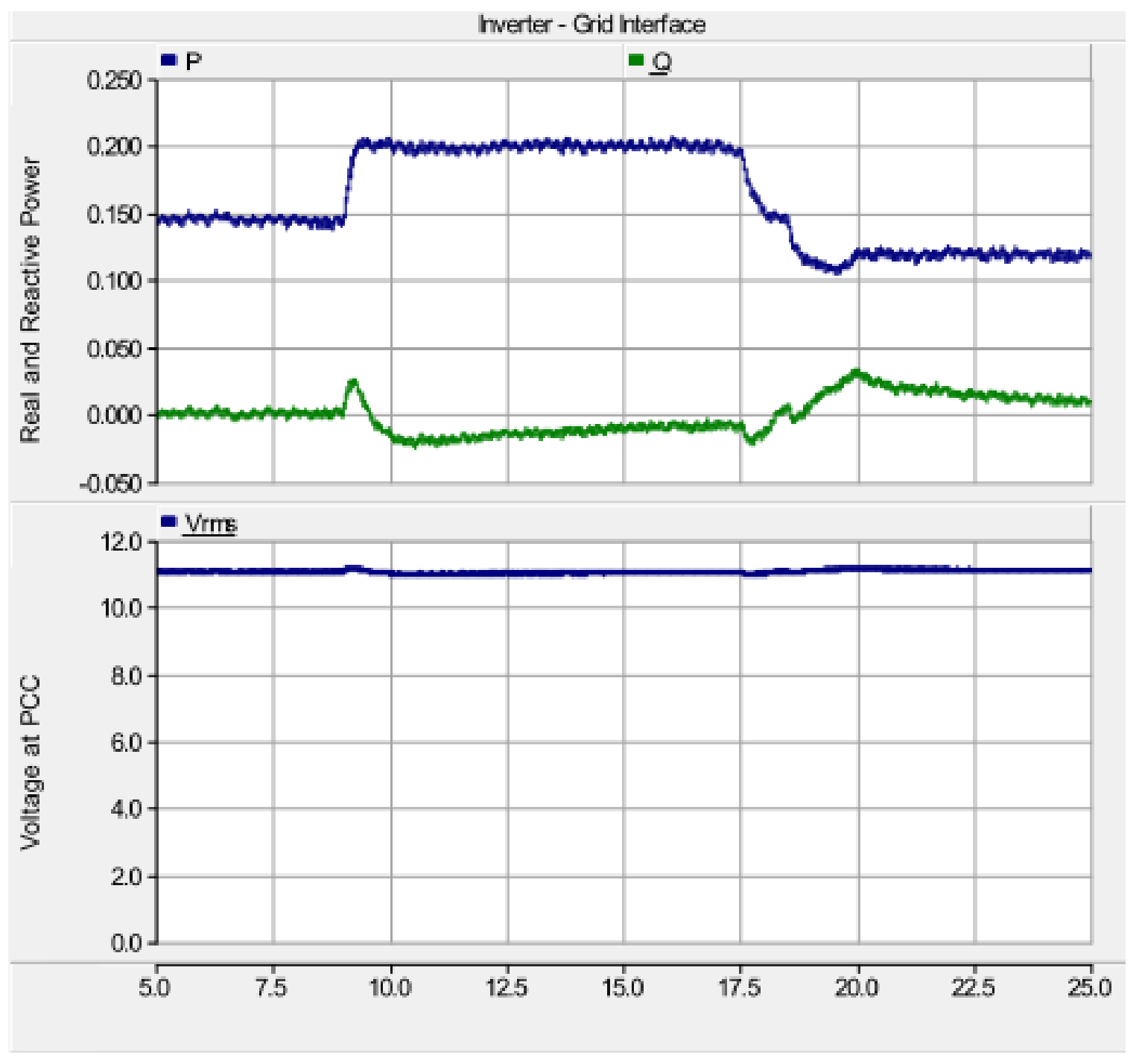

Figure 5-8: Real and Reactive Power at the Grid Interface

In the Greensmith model the inverter is experiencing transients due to the charging and discharging of the battery, which can vary in its amount of power delivered. Figure 4-10 showed that when a battery discharges, its voltage decreases. The opposite is true for a charge cycle. Therefore, a change in battery voltage corresponds to a change in the amount of battery power delivered or absorbed. Since the power is always changing, the inverter is not able to settle to a unity power factor. The continually varying battery power is why the Point of Common Coupling (PCC) sees a slight variation in voltage. 
The simulations were also run for five second transient periods each time. If the simulations were run for longer, the inverter controller would adjust the voltage to be closer to its rated value. Figure 5-9 is an example of a simulation run that has a 30 second transient period. The secondary of the transformer has a line-line RMS voltage of 208.8 V while the primary of the transformer has a line-line RMS voltage of $12.24 \mathrm{kV}$. Both of these voltages are close to their rated voltages of $208 \mathrm{~V}$ and $12.47 \mathrm{kV}$, respectively. The disadvantage of a longer transient period is that it takes much longer to simulate.

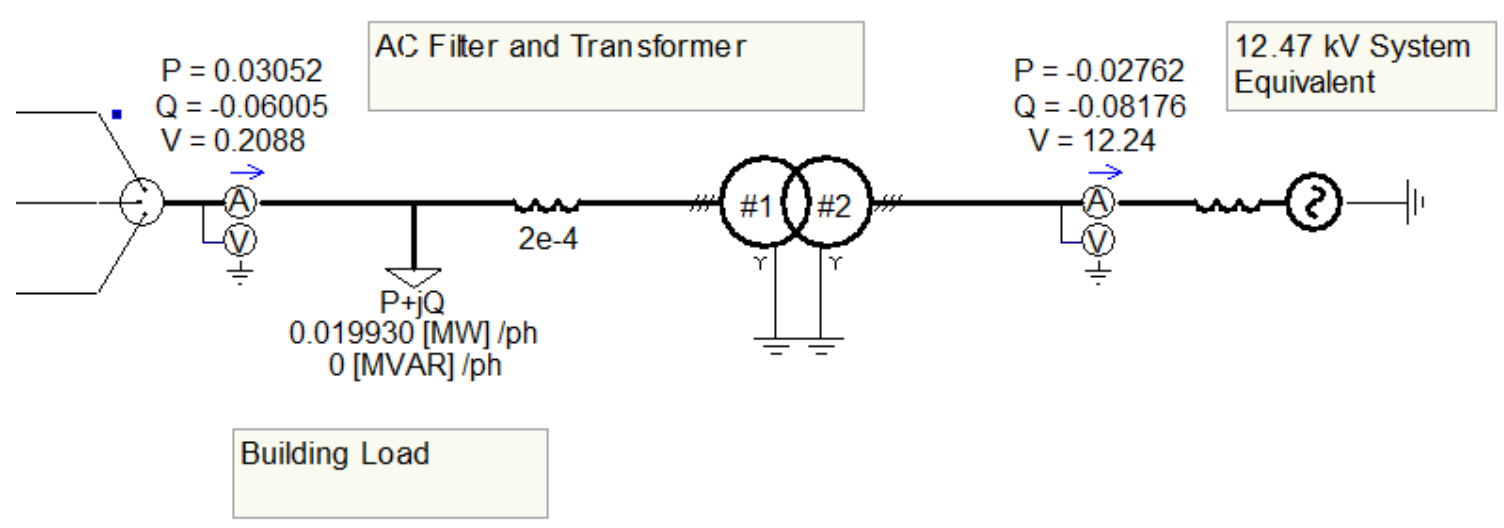

Figure 5-9: Long Simulation Run Example

Since the fixed load is set up as a constant power load, variations in voltage do not affect the loading. 


\section{FUTURE WORK}

\subsection{Battery Management System}

In order for the PSCAD model to more accurately represent the behavior of the equivalent Greensmith DESS model, it is desirable to have a Battery Management System (BMS). The Greensmith BMS monitors the instantaneous PV power generation and uses that information to make decisions on how to make use of the battery. If the PV is supplying ample power then the BMS either charges the battery or has it held on standby. However, if the PV power drops then the BMS discharges energy from the battery to compensate. The current PSCAD battery model is controlled by the battery control component. The battery control component controls the charging and discharging of the battery based upon its SOC. A Battery Management System that monitors the PV power would help make the PSCAD model behave more like the Greensmith DESS under the intermittency test.

\subsection{Smart Inverter}

The inverter controller used in this study is a simple $\mathrm{P}$ and $\mathrm{Q}$ regulator [12]. The inverter is set to operate at unity power factor, but during the transients, the reactive power output of the inverter changes. Fluctuations in reactive power can be minimized by improving the inverter control, for example by using decoupled controls based in d-q currents [12]. A better inverter design would be one based off a smart inverter. Some important system monitoring and grid-interactive features for an inverter to have are over and under voltage and frequency protection. 


\subsection{Single-Phase Inverter System Modeling}

This study made use of a three-phase inverter because the Greensmith DESS also used a three-phase inverter. The SDG\&E Skills Training Center is a medium/small commercial size building. It is not uncommon for commercial buildings to require threephase power in order to run their machinery. However, in residential applications it is far more common to encounter a single-phase inverter because most residential buildings and small businesses only need single-phase power. For future studies the same tests that were conducted in this study could be applied to a system that makes use of a singlephase inverter. SDG\&E has a second DESS system at their Energy Innovations Center (EIC) that makes use of a single-phase inverter. The system is Silent Power Inc.'s OnDemand ${ }^{\mathrm{TM}}$ Energy Appliance. The Silent Power system is sized at $10 \mathrm{~kW}$ of electrical output with $10 \mathrm{kWh}$ of energy storage and makes use of a lead acid battery pack. A picture of the Silent Power system is shown in Figure 6-1. The Silent Power system is enclosed in the wooden structure and the EIC is the building in the background.

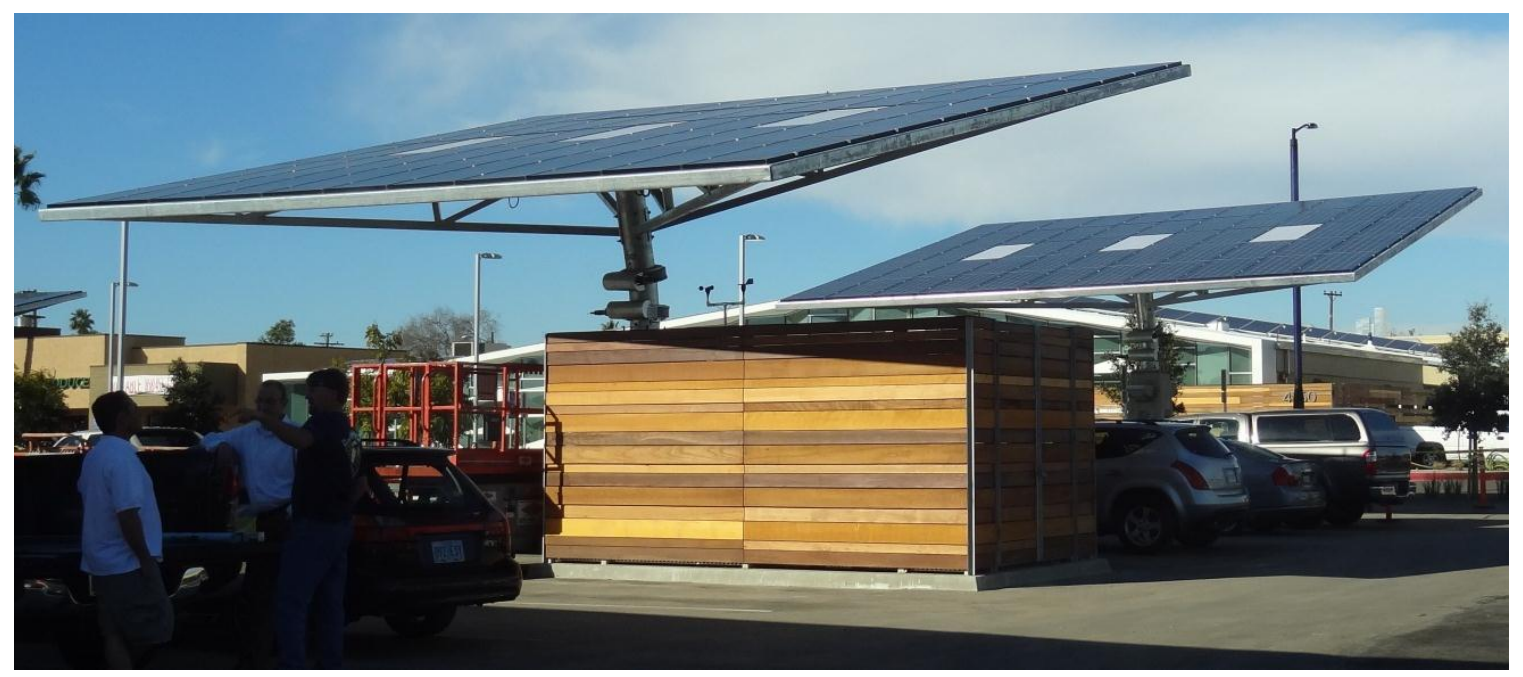

Figure 6-1: Silent Power System at the Energy Innovations Center 


\subsection{Harmonics and Power Quality Analysis}

One of the biggest concerns with grid connected PV inverters is the possibility of harmonic injection on to the grid. IEC standard 61727 "Photovoltaic (PV) systems Characteristics of the utility interface" and IEEE standard 929-2000 "Recommended practice for utility interface of photovoltaic systems" provide guidelines on harmonic limits at the Point of Common Coupling (PCC) [12]. At the PCC the current waveforms were quite visibly distorted [20]. The inverter current waveforms can be seen in Figure 6-2 [20].

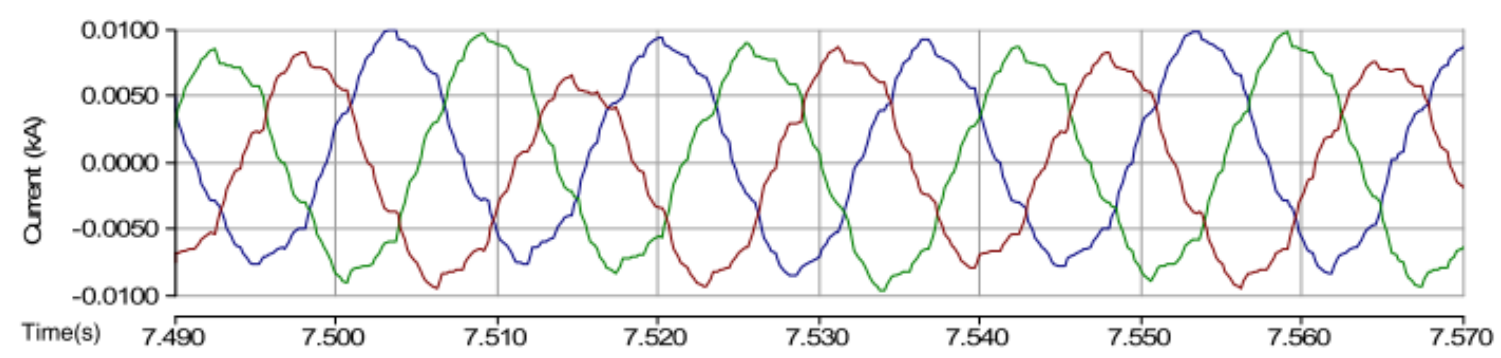

Figure 6-2: Inverter Output Current

In [20] the harmonics spectrums of these waveforms were further examined. Since the current waveforms are distorted they lead to corresponding distorted voltage waveforms. Figures 6-3 and 6-4 show the corresponding harmonic spectrums of the current and voltage waveforms respectively from the report [20]. 


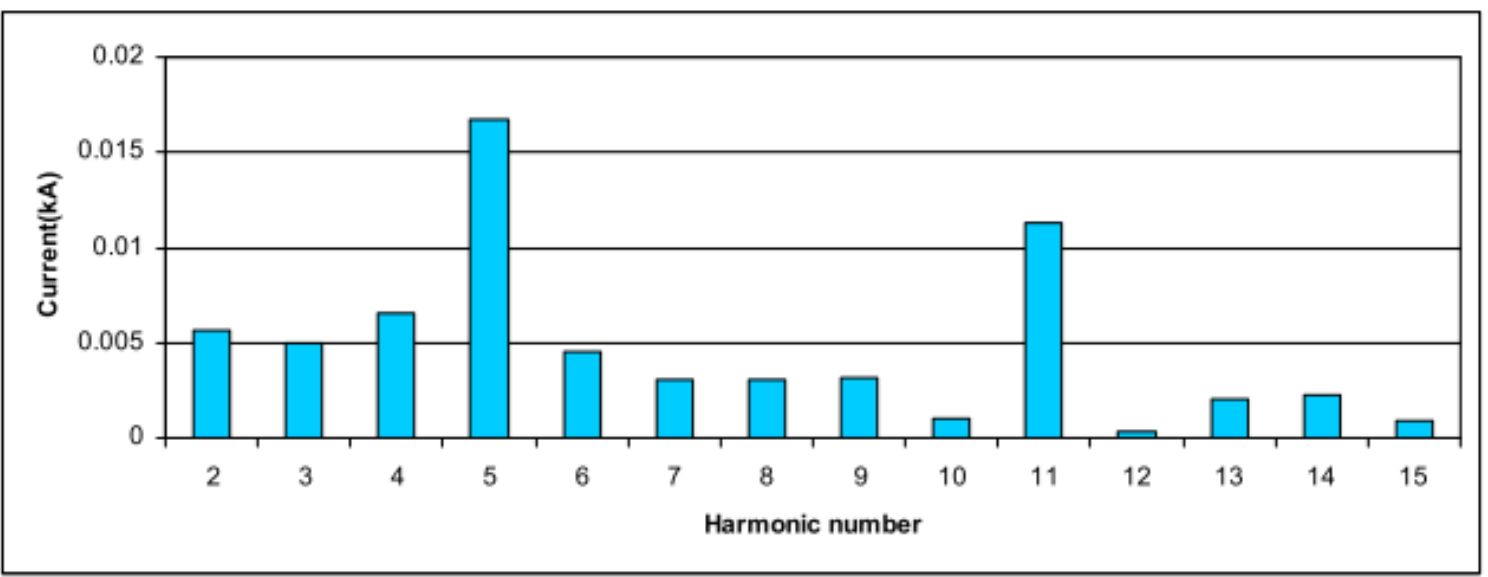

Figure 6-3: Harmonic Spectrum of the Inverter Current (Fundamental 0.28 kA)

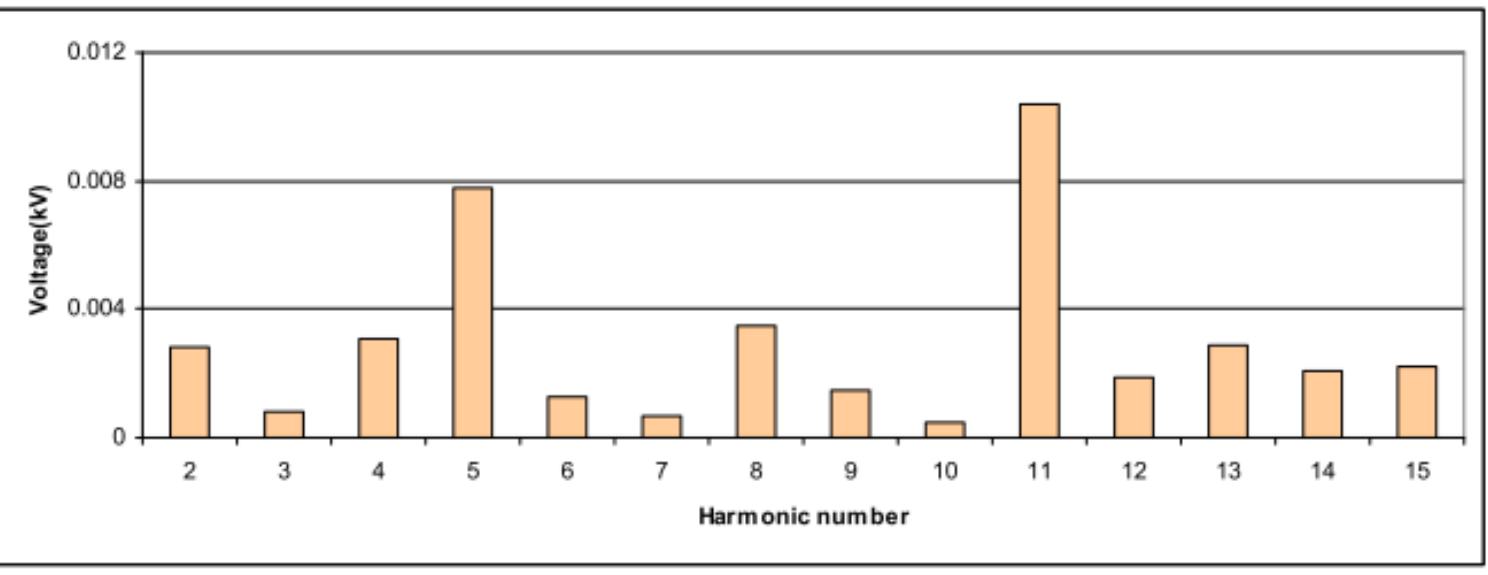

Figure 6-4: Harmonic Spectrum of the Voltage (Fundamental $7.43 \mathrm{kV}$ )

If the harmonic content of the system does not comply with the local utility then it would be desirable to install a filter at the PCC of the PV system [20]. Harmonics are another possible avenue for research related to PV systems.

\subsection{Peak Shaving}

In addition to smoothing out solar intermittency, energy storage systems could also be used for peak shaving. Solar output peaks at around 12 P.M. with the rotation of the Earth. However, residential load demand peaks at around 5-6 P.M. when most people are returning home from work. Therefore the period of 5-6 P.M. is considered to be peak 
residential load time. In most households nobody is home at noon and therefore there is more PV power generated than the local load demands. Typically when a PV array produces excess energy it 'sells' the power back to the grid. However, with the use of energy storage devices the excess energy could be stored in batteries to be later used that evening. Figure 6-5 demonstrates how this works over the course of a full day [21].

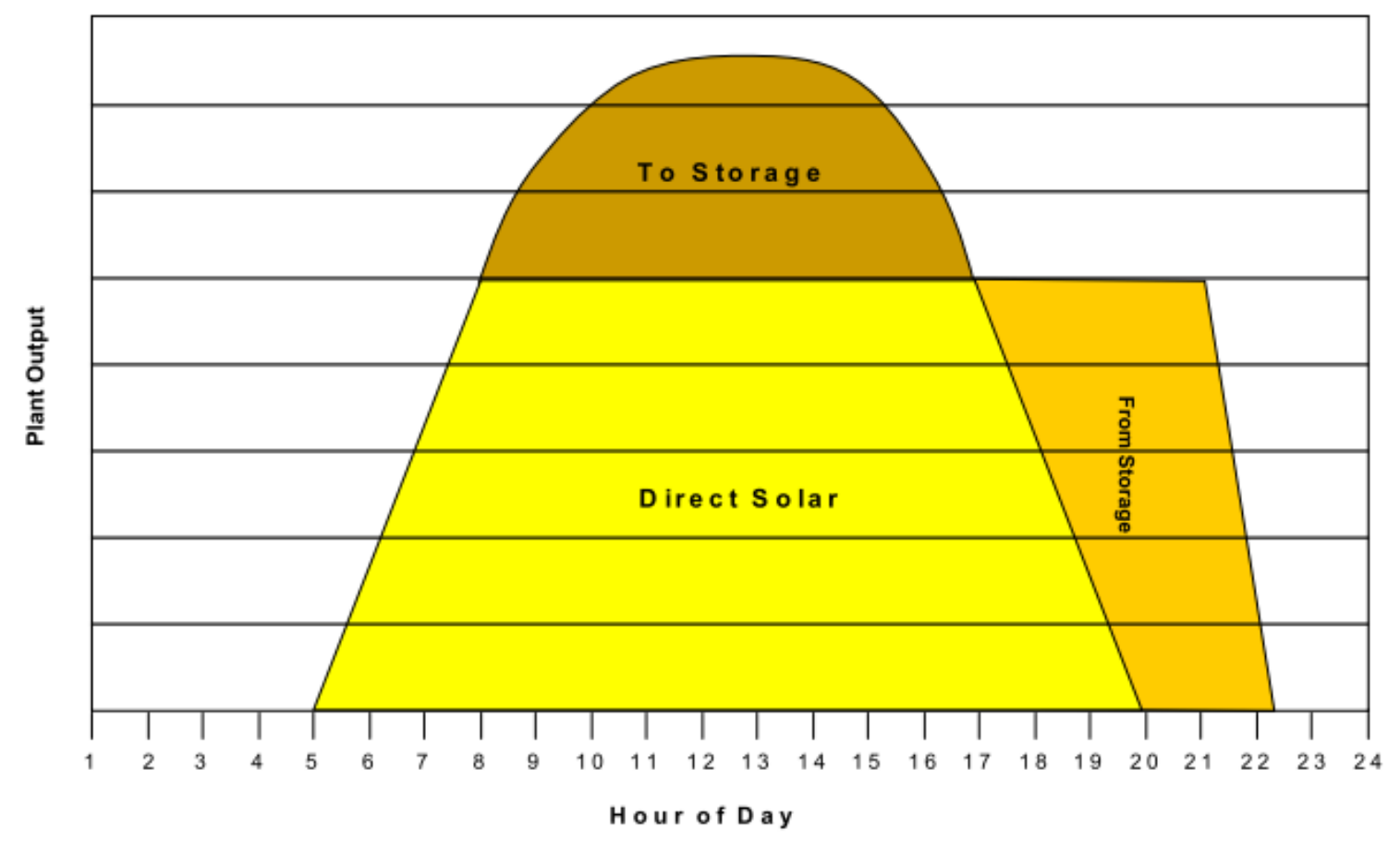

Figure 6-5: An Example of Peak Shaving

The use of energy storage devices for peak shaving is something that can be explored in future studies. Peak shaving has the potential to save the customer money by not purchasing power at peak load time. 
Environmental benefits and financial incentives are moving California's electrical supplies towards renewables. As one of the safest and most easily accessible forms of renewable technologies, solar system installations have increased greatly in recent history. With the increase in PV systems comes the need to examine some of the unique issues that they present. One of these issues is the problem of solar intermittency. PV arrays are subject to shading and temperature changes that make their power generation difficult to predict. One possible solution is to use a backup battery to supplement the PV array. The Electric Power Research Institute in conjunction with San Diego Gas and Electric have been researching the feasibility of using Distributed Energy Storage Systems to smooth out the power invariability from PV arrays. Test data collected on their Greensmith DESS show that the battery system does a good job of smoothing out the variability in the PV generation. The battery makes up the power to the load when the PV power output drops.

This study aimed to determine the performance of a photovoltaic system with a distributed energy storage system. More specifically, this study aimed to see if a DESS could be used to reduce the effect of solar intermittency. A DESS manufactured by Greensmith and installed at San Diego Gas \& Electric's Skill Training Center was the center point of this research. Experimental data from the system was examined along with computer-simulated data of the equivalent system model. The experimental data showed that the DESS is able to effectively compensate momentary drops in solar power. The Greensmith DESS was recreated in PSCAD and simulation testing was conducted on this model. Testing on the PSCAD model confirmed both the functionality of the 
Maximum Power Point Tracker as well as the DESS's ability to smooth out solar invariability. In both the real world experiment and the simulation, the use of a DESS helped to smooth out the load profile of the PV system. The DESS does an effective job of reducing the effect of solar intermittency.

In the short-term solar intermittency is not a large concern. However, in the future when solar energy becomes a substantial percentage of the electrical supply it will be necessary to have DESS's more prevalent in California's vast electrical utility system. 


\section{BIBLIOGRAPHY}

[1] K. Bullis, "Technology Review," MIT, 23 June 2006. [Online]. Available:

http://www.technologyreview.com/printer_friendly_article.aspx?id=17025. [Accessed 4 May 2012].

[2] REN21, "Renewables 2011: Global Status Report," REN21, Paris, 2011.

[3] U.S. Department of Energy, "U.S. Climate Change Technology Program: Technology Options for the Near and Long Term," U.S. Department of Energy, Washington D.C., 2003.

[4] L. Sherwood, "U.S. Solar Market Trends 2008," Interstate Renewable Energy Council, Latham, 2008.

[5] "Environmental Benefits of Solar," CleanSolarLiving, LLC, [Online]. Available: http://www.cleansolarliving.com/webpage.php?page=19. [Accessed 4 May 2012].

[6] "Go Solar California - Homepage," California Energy Commission \& California Public Utilities Commission, [Online]. Available: http://www.gosolarcalifornia.org/. [Accessed 5 January 2012].

[7] "Welcome to California Solar Statistics," California Energy Commission \& California Public Utilities Commission, [Online]. Available: http://www.californiasolarstatistics.ca.gov/. [Accessed 5 January 2012].

[8] C. Meehan, "Clean Energy Authority," Clean Energy Authority, 14 April 2011. [Online]. Available: http://www.cleanenergyauthority.com/solar-energy-news/california-makes-rps-into-law-041411/. [Accessed 4 May 2012].

[9] "San Diego, CA, California, USA: Climate, Global Warming, and Daylight Charts and Data," Climate-Charts, [Online]. Available: http://www.climate-charts.com/Locations/u/US72290000477401.php. [Accessed 4 May 2012].

[10] "The Need for Electricity Storage," MegaWatt Storage Farms, Inc., [Online]. Available: http://www.megawattsf.com/gridstorage/gridstorage.htm. [Accessed 4 May 2012].

[11] Sandia National Laboratories, Stand-Alone Photovoltaic Systems: A Handbook of Recommended Design Practices, Springfield: National Technical Information Service, 1995.

[12] A. D. Rajapakse and D. Muthumuni, "Simulation Tools for Photovoltaic System Grid Integration Studies," IEEE Electrical Power and Energy Conference, EPEC, 2009.

[13] A. D. Rajapakse, "Simulation of Grid Connected Photovoltaic Systems," PULSE, vol. October, no. 2008, pp. 6-7, 2008.

[14] Y.-J. M. Tung, A. P. Hu and N.-K. Nair, "Evaluation of Micro Controller Based Maximum Power Point Tracking Methods Using dSPACE Platform," Australian University Power Engineering Conference, Auckland, 2006.

[15] Z. Yu and K. Ogboenyira, "Renewable Energy Through Micro-Inverters," Power Electronics Technology, 1 April 2009. [Online]. Available:

http://powerelectronics.com/power_semiconductors/power_microinverters_computercontrolled_improve_0409/. [Accessed 4 May 2012].

[16] S. Jiang, "Battery Component in PSCAD/EMTDC," Manitoba HVDC Research Centre, Winnipeg, 2012. 
[17] O. Tremblay, L.-A. Dessaint and A.-I. Dekkiche, "A Generic Battery Model for the Dynamic Simulation of Hybrid Electric Vehicles," IEEE, 2007.

[18] O. Tremblay and L.-A. Dessaint, "Experimental Validation of a Battery Dynamic Model for EV Applications," World Electric Vehicle Journal, vol. 3, pp. 1-10, 2009.

[19] R. A. Messenger and J. Ventre, in Photovoltaic Systems Engineering, Boca Raton, CRC Press, 2010, p. 216.

[20] "Calculation of Solar Insolation," PVEducation.org, [Online]. Available: http://pveducation.org/pvcdrom/properties-of-sunlight/calculation-fo-solar-insolation. [Accessed 4 May 2012].

[21] A. Rajapakse, D. Muthumuni and N. Perera, "Grid Integration of Renewable Energy Systems," InTech, 2009.

[22] L. Stoddard, J. Abiecunas and R. O'Connell, "Economic, Energy, and Environmental Benefits of Concentrating Solar Power in California," National Renewable Energy Laboratory, Golden, 2006.

[23] C. M. Shepherd, "Design of Primary and Secondary Cells - Part 2. An Equation Describing Battery Discharge," Journal of Electrochemical Society, vol. 112, pp. 657-664, 1965. 


\section{APPENDIX A: Grid-Connected PV Installations by State}

Table A-1: Grid-Connected PV Installations by State

\begin{tabular}{|c|c|c|c|}
\hline State & $\begin{array}{r}\text { Capacity Installed in } \\
2007\left(\mathrm{MW}_{\mathrm{DC}}\right)\end{array}$ & $\begin{array}{r}\text { Capacity Installed in } \\
2008\left(\mathrm{MW}_{\mathrm{DC}}\right)\end{array}$ & $\begin{array}{r}\text { Cumulative Installed } \\
\text { Capacity }\left(\mathrm{MW}_{\mathrm{DC}}\right)\end{array}$ \\
\hline Alabama & $*$ & $*$ & $*$ \\
\hline Alaska & $*$ & * & * \\
\hline Arizona & 2.8 & 6.4 & 25.3 \\
\hline Arkansas & $*$ & $*$ & * \\
\hline California & 91.8 & 178.7 & 528.3 \\
\hline Colorado & 11.5 & 21.7 & 35.7 \\
\hline Connecticut & 2.5 & 5.3 & 8.8 \\
\hline Delaware & 0.4 & 0.6 & 1.8 \\
\hline District of Columbia & $*$ & 0.2 & 0.7 \\
\hline Florida & 1.0 & 0.9 & 3.0 \\
\hline Georgia & $*$ & $*$ & * \\
\hline Hawaii & 2.9 & 8.6 & 13.5 \\
\hline Idaho & $*$ & $*$ & * \\
\hline Illinois & 0.2 & 0.4 & 2.8 \\
\hline Indiana & * & $*$ & $*$ \\
\hline Iowa & $*$ & * & * \\
\hline Kansas & $*$ & * & * \\
\hline Kentucky & $*$ & * & * \\
\hline Louisiana & $*$ & $*$ & * \\
\hline Maine & $*$ & * & 0.3 \\
\hline Maryland & 0.3 & 2.2 & 3.1 \\
\hline Massachusetts & 1.4 & 2.9 & 7.5 \\
\hline Michigan & $*$ & $*$ & 0.4 \\
\hline Minnesota & 0.3 & 0.3 & 1.0 \\
\hline Mississippi & $*$ & $*$ & * \\
\hline Missouri & $*$ & * & * \\
\hline Montana & 0.2 & 0.1 & 0.7 \\
\hline Nebraska & $*$ & $*$ & * \\
\hline Nevada & 15.9 & 14.9 & 34.2 \\
\hline New Hampshire & $*$ & * & 0.1 \\
\hline New Jersey & 20.4 & 22.5 & 70.2 \\
\hline New Mexico & 0.2 & 0.6 & 1.0 \\
\hline New York & 3.8 & 7.0 & 21.9 \\
\hline North Carolina & 0.4 & 4.0 & 4.7 \\
\hline North Dakota & $*$ & $*$ & $*$ \\
\hline Ohio & 0.1 & 0.4 & 1.4 \\
\hline Oklahoma & $*$ & $*$ & * \\
\hline Oregon & 1.1 & 4.8 & 7.7 \\
\hline Pennsylvania & 0.1 & 3.0 & 3.9 \\
\hline Rhode Island & $*$ & $*$ & 0.6 \\
\hline South Carolina & $*$ & $*$ & * \\
\hline South Dakota & * & * & * \\
\hline Tennessee & $*$ & $*$ & 0.4 \\
\hline Texas & 0.6 & 1.2 & 4.4 \\
\hline Utah & $*$ & $*$ & 0.2 \\
\hline Vermont & 0.2 & 0.4 & 1.1 \\
\hline Virginia & $*$ & * & 0.2 \\
\hline Washington & 1.2 & 0.8 & 3.7 \\
\hline West Virginia & $*$ & $*$ & $*$ \\
\hline Wisconsin & 0.6 & 1.7 & 3.1 \\
\hline Wyoming & $*$ & $*$ & * \\
\hline
\end{tabular}

* less than $100 \mathrm{~kW}_{\mathrm{dc}}$ or data not available 


\section{APPENDIX B: Greensmith Power Vault 50 Datasheet}

\section{\# GREENSMITH}

Delivering the value of advanced energy storage

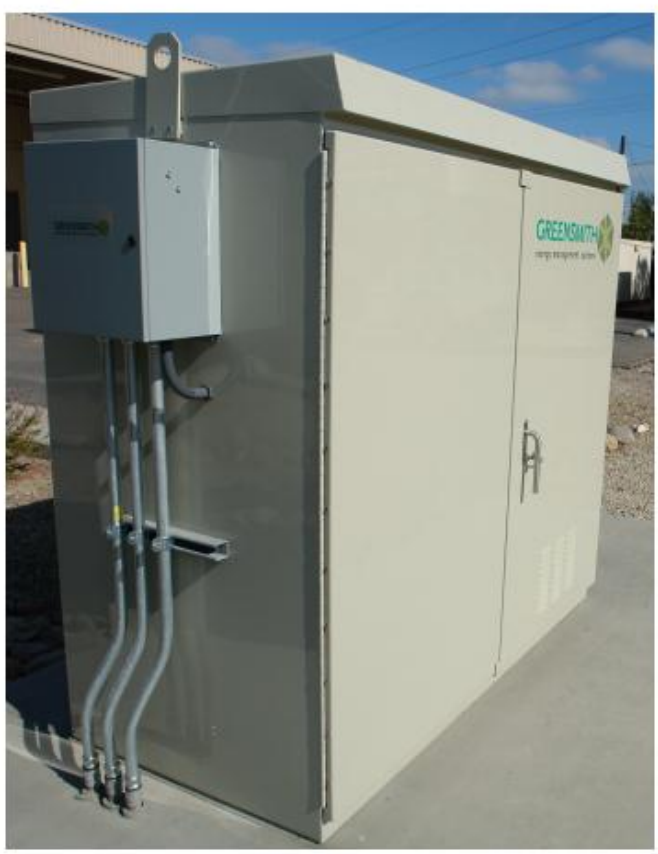

\section{Power Vault 50}

\section{$50 \mathrm{KWh}$}

\section{Distributed Energy Storage Unit}

GS-BP-50-25: 25 KVA

Greensmith Battery Operating System III

Uniform battery operating environment, communication and control protocols across all Greensmith units

\section{Advanced BMS}

- Real-time battery module measurement and report: voltage, current, temperature, Cell Capacity, SOC, Efficiency and SOH

- Active balancing that keeps cells balanced at all times

- Battery module protections against under/over-voltage, temperature and over current

\begin{tabular}{|c|c|c|}
\hline \multicolumn{3}{|l|}{ Power } \\
\hline \multirow[t]{3}{*}{ AC Voltage Options } & $208 V_{A C}$ & $183-229 V_{A C}$ \\
\hline & $240 V_{A C}$ & $211-264 V_{A C}$ \\
\hline & $480 V_{A C}$ & $422.528 \mathrm{~V}_{\mathrm{AC}}$ \\
\hline $\begin{array}{l}\text { Maximum Continuous } \\
\text { Power Options }\end{array}$ & $25 \mathrm{KW}(25 \mathrm{KVA})$ & $\begin{array}{l}\text { Charge or } \\
\text { discharge }\end{array}$ \\
\hline $\begin{array}{l}\text { Maximum Reactive } \\
\text { Power Options }\end{array}$ & $25 \mathrm{KVR}$ & $\begin{array}{l}\text { Capacitive or } \\
\text { inductive }\end{array}$ \\
\hline $\begin{array}{l}\text { Maximum Power } \\
\text { Ramp Time }\end{array}$ & $<2$ Seconds & $\begin{array}{l}\text { Ramp Rate } \\
\text { Adjustable }\end{array}$ \\
\hline Number of Phases & 3 & \\
\hline \multirow{3}{*}{$\begin{array}{l}\text { Maximum Current per } \\
\text { Phase } \\
\text { (25 KVA Model) }\end{array}$} & $70 \mathrm{~A}$ & $208 V_{A C}$ \\
\hline & $62 \mathrm{~A}$ & $240 \mathrm{~V}_{\mathrm{AC}}$ \\
\hline & $30 \mathrm{~A}$ & $480 V_{A C}$ \\
\hline $\begin{array}{l}\text { Nominal Grid } \\
\text { Frequency }\end{array}$ & $60 \mathrm{~Hz}$ & Adjustable \\
\hline Grid Frequency Range & $59.3-60.5 \mathrm{~Hz}$ & Adjustable \\
\hline Power Factor & $>0.99$ & At Full Load \\
\hline
\end{tabular}

- In-field configurations: DOD, voltage protection ranges, power ramp rates and charge rates

- Dynamic, real-time power control. Switch between charge and discharge in less than 2 seconds

- Ethernet, serial and Web-based communication and control

- Peer-to-peer networking across multiple units to form larger, virtual unit

- Support drop-in custom modules

- Smart Grid ready

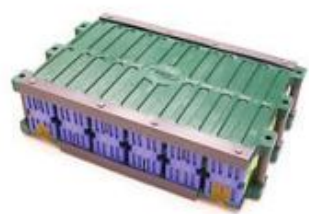

Figure B-1: Greensmith Power Vault 50 Datasheet Page 1 


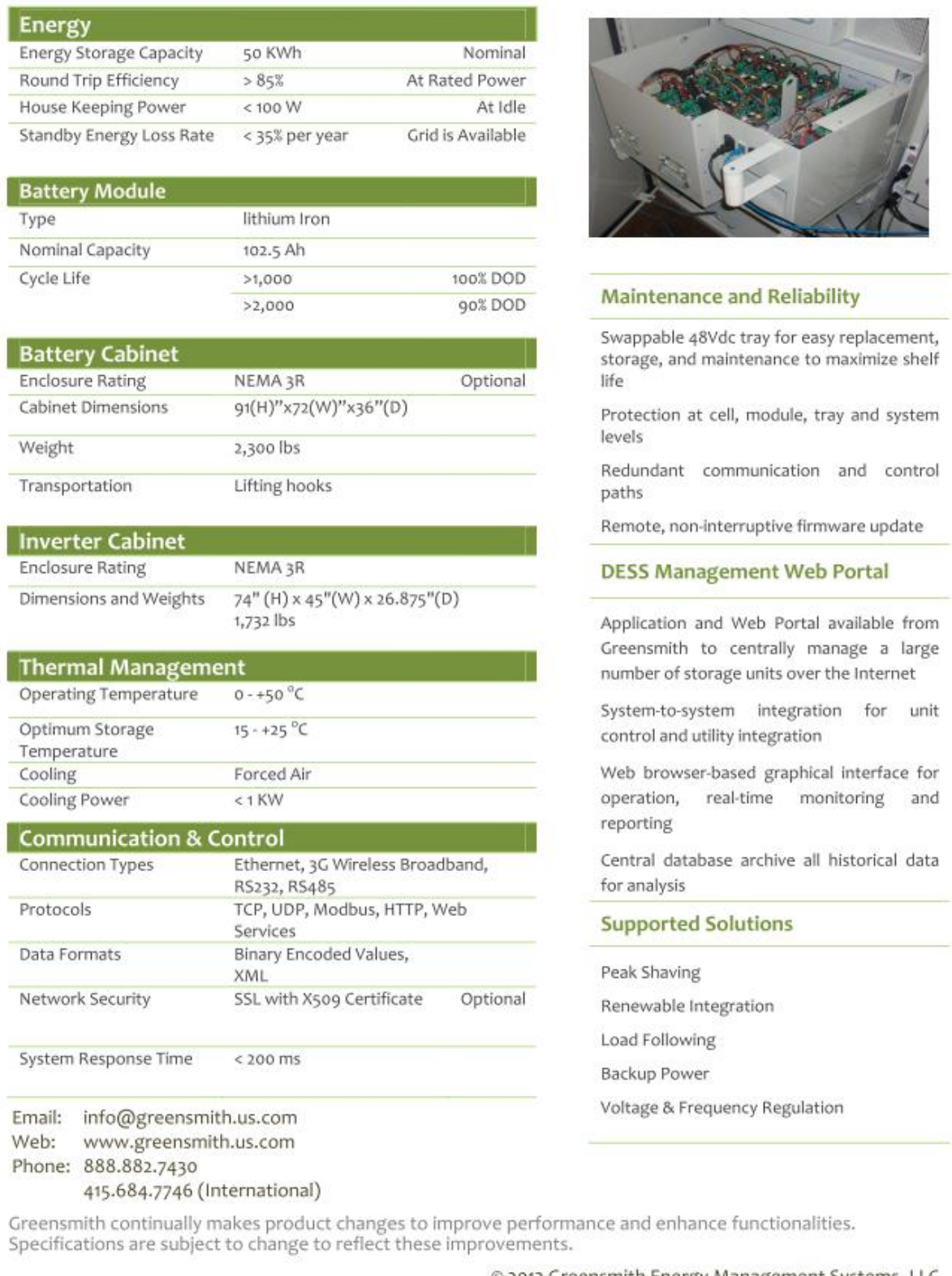

(c) 2012 Greensmith Energy Management Systems, LLC

Figure B-2: Greensmith Power Vault 50 Datasheet Page 2 


\section{APPENDIX C: PowerGate Plus 50kW UL Datasheet}

\section{PowerGate Plus 50 kW UL}

Streamlined Design

With all components encased in

a single, space-saving enclosure,

PowerGate Plus $\mathrm{PV}$ inverters are easy

to install, operate and maintain.

Rugged Construction

- Engineered for outdoor environments - Wide thermal operating range: from
$-4^{\circ} \mathrm{F}$ to $+122^{\circ} \mathrm{F}\left(-20^{\circ} \mathrm{C}\right.$ to $\left.+50^{\circ} \mathrm{C}\right)$ without derating

- Solar shield attached to exterior of enclosure dissipate solar radiation, reduce heat buildup

- Single cooling fans

- Single cabinet with small footprint

Easy Maintenance

- Modular components make

service efficient

- Convenient access to all components

- Customizable large in-floor cable gland plates make installation of DC and $A C$ cables easy

- Integrated DC two-pole disconnect switch isolates the inverter, with the exception of the GFDI (Ground Fault Detection and Interruption) circuit, from the photovoltaic power system

Proven Reliability

Rugged and reliable, PowerGate Plus $\mathrm{PV}$ inverters are engineered from the ground up to meet the demands of

Safety

- UBC seismic Zone 4 compliant

- Built-in DC and AC disconnect switches

- Protective covers over exposed power connections

Output Transformer

- Provides galvanic isolation

- Matches the output voltage of the PV inverter to the grid

\begin{tabular}{|c|c|c|c|c|}
\hline \multicolumn{2}{|c|}{ PowerGate Plus 50 kW Specifications } & \multicolumn{3}{|c|}{ ULCSA } \\
\hline \multicolumn{5}{|l|}{ Input Parameters } \\
\hline \multicolumn{2}{|l|}{ Input Voltage Range } & \multicolumn{3}{|c|}{$305-600$ VDC } \\
\hline \multicolumn{2}{|l|}{ Maximum Array Input Voltage } & \multicolumn{3}{|c|}{$600 \mathrm{VDC}$} \\
\hline \multicolumn{2}{|c|}{ Maximum Operating Input Current' ${ }^{1}$} & \multicolumn{3}{|c|}{$172 \mathrm{ADC}$} \\
\hline \multirow[t]{2}{*}{ PV Array Configuration } & $\begin{array}{l}\text { Negative } \\
\text { Ground }\end{array}$ & \multicolumn{3}{|c|}{$\bullet$} \\
\hline & $\begin{array}{l}\text { Positive } \\
\text { Ground }\end{array}$ & \multicolumn{3}{|c|}{$\bullet$} \\
\hline \multicolumn{5}{|l|}{ DC Input Combiner Options } \\
\hline Combiner Bus Bar Inputs & $\bullet$ & \multicolumn{3}{|c|}{6} \\
\hline Number of Inputs and Fuses & $\circ$ & \multicolumn{3}{|c|}{$\begin{array}{l}4 \times 80 \mathrm{~A} \\
5 \times 63 \mathrm{~A}\end{array}$} \\
\hline \multicolumn{5}{|l|}{ Transformer } \\
\hline Integrated Transformer ${ }^{2}$ & & \multicolumn{3}{|c|}{ Yes } \\
\hline \multicolumn{5}{|l|}{ Efficiency } \\
\hline \multicolumn{2}{|l|}{ Maximum $^{3}$} & $95.9 \%$ & $96.2 \%$ & $96.4 \%$ \\
\hline \multicolumn{2}{|l|}{ CEC } & \\
\hline \multicolumn{2}{|l|}{ Output Parameters } & \multicolumn{3}{|c|}{$95.5 \%$} \\
\hline \multicolumn{2}{|l|}{ Nominal Power } & \multicolumn{3}{|c|}{$50 \mathrm{~kW}$} \\
\hline \multicolumn{2}{|l|}{ Nominal Output Voltage } & 208 VAC & 240 VAC & 480 VAC \\
\hline \multicolumn{2}{|c|}{ Output Voltage Range, $[-12 \% / 10 \%]$} & 183-229 VAC & 211-264 VAC & 422-526 VAC \\
\hline \multicolumn{2}{|l|}{ Maximum Output Current/Phase } & $139 \mathrm{~A}$ & $121 \mathrm{~A}$ & $60 \mathrm{~A}$ \\
\hline \multicolumn{2}{|c|}{$\begin{array}{l}\text { Standby Consumptions (tare losses } \\
\text { including control power and aux.) }\end{array}$} & $75 w$ & $94 \mathrm{~W}$ & $76 \mathrm{~W}$ \\
\hline \multicolumn{2}{|c|}{ Nominal Output Frequency, 3-Phase } & \multicolumn{3}{|c|}{$60 \mathrm{~Hz}$} \\
\hline Maximum Harmonic Distortion & & & $<3 \%$ THD & \\
\hline Power Factor, Full Load & & & $>99 \%$ & \\
\hline Dynamic Power Factor Contro & & & $+1-0.8$ & \\
\hline Power Curtailment & & & $0-100 \%, 1 \%$ step & \\
\hline Environment & & & & \\
\hline $\begin{array}{l}\text { Operating Temperature Range } \\
\text { (Nominal Power) }\end{array}$ & & $-4^{\circ} \mathrm{F}$ & $\begin{array}{l}+122^{\circ} \mathrm{F}\left(-20^{\circ} \mathrm{C} \text { to }\right. \\
\text { pt. }-40^{\circ} \mathrm{C} \text { to }+50^{\circ}\end{array}$ & $\left.0^{\circ} \mathrm{C}\right)$ \\
\hline Storage Temperature Range & & $-22^{\circ} \mathrm{F}$ & $+158^{\circ} \mathrm{F}\left(-30^{\circ} \mathrm{C} \mathrm{t}\right.$ & $\left.70^{\circ} \mathrm{C}\right)$ \\
\hline Cooling & & & Forced Air & \\
\hline Noise Level (Distance of $3 \mathrm{~m}$ ) & & & $<65 \mathrm{~dB}(\mathrm{~A})$ & \\
\hline Relative Humidity (Non-Conde & רsing) & & up to $90 \%$ & \\
\hline
\end{tabular}

Figure C-1: PowerGate Plus 50kW UL Datasheet 


\section{APPENDIX D: International Battery IB-B-FHE-160 Datasheet}

\section{international battery}

High Energy Large Prismatic Rechargeable Cell

Lithium-Iron Phosphate Cells (LiFePO4)

International Battery, Inc.'s Iron Phosphate rechargeable cells are available in a rugged prismatic format in capacities ranging from 40 - 160Ah. LiFePO4 is an intrinsically safe cathode material. LiFePO4 cells do not incinerate or explode under extreme conditions. LiFePO4 cells have a high discharge current, are not toxic and have a high cycle life. The specific geometries of these cells allow for even electrode utilization, good heat dissipation and efficient packaging. IB's cells offer a low self-discharge rate and have excellent operating temperature characteristics. The excellent thermal stability and safety performance of the Lithium Iron Phosphate electrochemical system is well suited for variety of commercial, military and industrial applications.

Features: $\quad$ Very High Specific Energy, Long Cycle Life

Applications: Electric vehicles, electric buses, electric scooters, military applications, communications, backup power, energy storage (wind, solar, tidal).

\begin{tabular}{|c|c|c|c|c|}
\hline \multicolumn{5}{|c|}{ LiFePO4 Packaged Cells } \\
\hline Specification & Condition & IB-B-FHE-40 & IB-B-FHE-60 & IB-B-FHE-160 \\
\hline Nominal Voltage & $(\mathrm{C} / 3)$ & 3.2 Volts & 3.2 Volts & 3.2 Volts \\
\hline Nominal Capacity & $(\mathrm{C} / 3)$ & $40 \mathrm{Ah}$ & $60 \mathrm{Ah}$ & $160 \mathrm{Ah}$ \\
\hline Nominal Energy & $(\mathrm{C} / 3)$ & $128 \mathrm{Wh}$ & $192 \mathrm{Wh}$ & $512 \mathrm{Wh}$ \\
\hline Specific Energy & $(\mathrm{C} / 3)$ & $88 \mathrm{Wh} / \mathrm{Kg}$ & $87 \mathrm{Wh} / \mathrm{Kg}$ & $94 \mathrm{Wh} / \mathrm{Kg}$ \\
\hline Peak Power (60\% DOD) & $30 \mathrm{sec}, 2 / 3 \mathrm{OCV}, 60 \%$ & 750 W (517 W/Kg) & $1300 \mathrm{~W}(517 \mathrm{~W} / \mathrm{Kg})$ & $3000 \mathrm{~W}(555 \mathrm{~W} / \mathrm{Kg})$ \\
\hline Peak Power (60\% DOD) & $30 \mathrm{sec}, 2 / 3 \mathrm{OCV}, 60 \%$, Active Cooling & $1050 \mathrm{~W}(724 \mathrm{~W} / \mathrm{Kg})$ & $1800 \mathrm{~W}(818 \mathrm{~W} / \mathrm{Kg})$ & $4200 \mathrm{~W}(778 \mathrm{~W} / \mathrm{Kg})$ \\
\hline DC Pulse Resistance & $10 \mathrm{sec}, 5 \mathrm{C}, 60 \% \mathrm{DOD}$ & $3.0 \mathrm{~m} \Omega$ & $2.0 \mathrm{~m} \Omega$ & $.75 \mathrm{~m} \Omega$ \\
\hline Self-Discharge Rate & Monthly, RT & $<3 \%$ & $<3 \%$ & $<3 \%$ \\
\hline Cycle Life @ $25^{\circ} \mathrm{C}$ & $100 \%$ DOD & $>2000$ Cycles & $>2000$ Cycles & $>2000$ Cycles \\
\hline Cycle Life @ $55^{\circ} \mathrm{C}$ & $100 \%$ DOD, 1C, Active Cooling & $>1000$ Cycles & $>1000$ Cycles & $>1000$ Cycles \\
\hline Cell Weight & Integrated Cell & $1.45 \mathrm{Kg}$ & $2.2 \mathrm{Kg}$ & $5.4 \mathrm{Kg}$ \\
\hline Recommended Cutoff Voltages & $\begin{array}{l}\text { Charge } \\
\text { Discharge }\end{array}$ & $\begin{array}{l}3.6 \text { Volts } \\
2.5 \text { Volts }\end{array}$ & $\begin{array}{l}3.6 \text { Volts } \\
2.5 \text { Volts }\end{array}$ & $\begin{array}{l}3.6 \text { Volts } \\
2.5 \text { Volts }\end{array}$ \\
\hline Safe Operating Ranges & $\begin{array}{l}\text { Max } \\
\text { Min }\end{array}$ & $\begin{array}{l}3.6 \text { Volts } \\
2.5 \text { Volts }\end{array}$ & $\begin{array}{l}3.6 \text { Volts } \\
2.5 \text { Volts }\end{array}$ & $\begin{array}{l}3.6 \text { Volts } \\
2.5 \text { Volts }\end{array}$ \\
\hline Max Pulse Current (<30 sec) & $>2.5$ Volts & $200 \mathrm{~A}(5 \mathrm{C})$ & $300 \mathrm{~A}(5 \mathrm{C})$ & $800 \mathrm{~A}(5 \mathrm{C})$ \\
\hline Max Pulse Current (<30 sec) & $>2.5$ Volts, Active Cooling & $280 \mathrm{~A}(7 \mathrm{C})$ & $420 \mathrm{~A}(7 \mathrm{C})$ & $1120 \mathrm{~A}(7 \mathrm{C})$ \\
\hline Max Continuous Charge Current & $100 \%$ DOD & $20 \mathrm{~A}(\mathrm{C} / 2)$ & $30 \mathrm{~A}(\mathrm{C} / 2)$ & $80 \mathrm{~A}(\mathrm{C} / 2)$ \\
\hline Max Continuous Charge Current & $100 \%$ DOD, Active Cooling & $40 \mathrm{~A}(\mathrm{C})$ & $60 \mathrm{~A}(\mathrm{C})$ & $160 A(C)$ \\
\hline Max Continuous Discharge Current & $10 \%$ to $90 \% \mathrm{DOD}$ & $40 \mathrm{~A}(\mathrm{C})$ & $60 \mathrm{~A}(\mathrm{C})$ & $160 \mathrm{~A}(\mathrm{C})$ \\
\hline Max Continuous Discharge Current & $10 \%$ to $90 \%$ DOD, Active Cooling & $120 \mathrm{~A}(3 \mathrm{C})$ & $180 \mathrm{~A}(3 \mathrm{C})$ & $480 \mathrm{~A}(3 \mathrm{C})$ \\
\hline $\begin{array}{l}\text { Charging Efficiency } \\
\text { (Ratio of charge/discharge time) }\end{array}$ & $\begin{array}{l}100 \% \text { DOC @ C } 3 \text {. } \\
10 \% \text { to } 90 \% \text { DOC @ C } / 3\end{array}$ & $\begin{array}{l}96 \% \\
99 \%\end{array}$ & $\begin{array}{l}94 \% \\
98 \%\end{array}$ & $\begin{array}{l}90 \% \\
98 \%\end{array}$ \\
\hline Operating Temperature & $\begin{array}{l}\text { Charge } \\
\text { Discharge }\end{array}$ & $\begin{array}{l}0^{\circ} \mathrm{C} \text { to } 50^{\circ} \mathrm{C} \\
-20^{\circ} \mathrm{C} \text { to } 55^{\circ} \mathrm{C}\end{array}$ & $\begin{array}{l}0^{\circ} \mathrm{C} \text { to } 50^{\circ} \mathrm{C} \\
-20^{\circ} \mathrm{C} \text { to } 55^{\circ} \mathrm{C}\end{array}$ & $\begin{array}{l}0^{\circ} \mathrm{C} \text { to } 50^{\circ} \mathrm{C} \\
-20^{\circ} \mathrm{C} \text { to } 55^{\circ} \mathrm{C}\end{array}$ \\
\hline Storage Temperature & & $-30^{\circ} \mathrm{C}$ to $60^{\circ} \mathrm{C}$ & $-30^{\circ} \mathrm{C}$ to $60^{\circ} \mathrm{C}$ & $-30^{\circ} \mathrm{C}$ to $60^{\circ} \mathrm{C}$ \\
\hline Calender Life & & 10 years & 10 years & 10 years \\
\hline
\end{tabular}

Copyright 2009 International Battery, Inc. All rights reserved. All trademarks and registered trademarks are properties of their respective owners.

Figure D-1: International Battery IB-B-FHE-160 Datasheet Page 1 

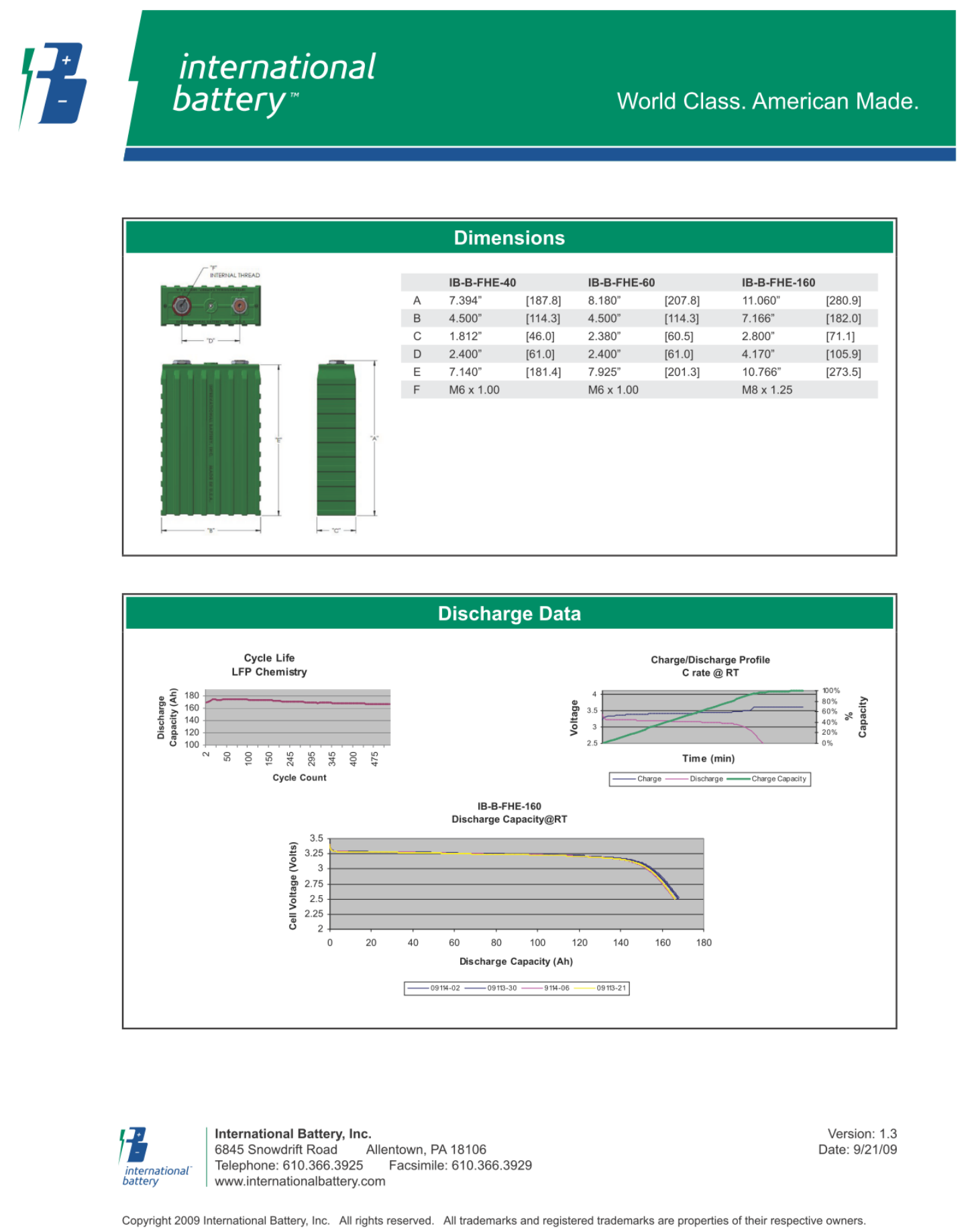

Figure D-2: International Battery IB-B-FHE-160 Datasheet Page 2 